\title{
WORLD TRADE
}

\section{ORgANIZATION}

WT/DS315/AB/R

13 November 2006

(06-5450)

Original: English

\section{EUROPEAN COMMUNITIES - SELECTED CUSTOMS MATTERS}

AB-2006-4

Report of the Appellate Body 



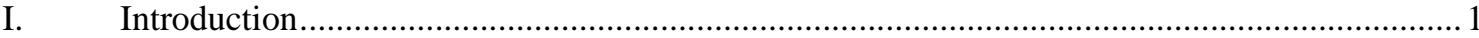

II. Arguments of the Participants and the Third Participants .......................................................... 7

A. Claims of Error by the United States - Appellant ....................................................... 7

1. The Panel's Terms of Reference ………........................................................... 7

2. Claims regarding Article X:3(a) of the GATT 1994 ......................................11

3. The Panel's Interpretation of Article X:3(b) of the GATT 1994..................... 15

B. Arguments of the European Communities - Appellee ....................................................17

1. The Panel's Terms of Reference …………...................................................... 17

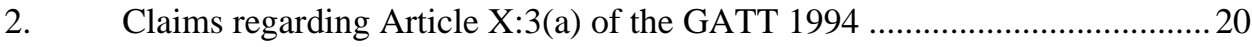

3. The Panel's Interpretation of Article X:3(b) of the GATT 1994_.................... 23

C. Claims of Error by the European Communities - Other Appellant ...............................26

1. The Panel's Terms of Reference ........................................................................26

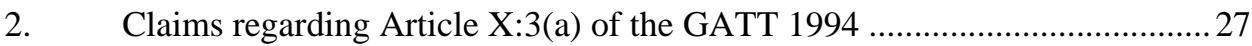

3. Conditional Appeal of the European Communities ............................................ 33

D. Arguments of the United States - Appellee ....................................................................... 34

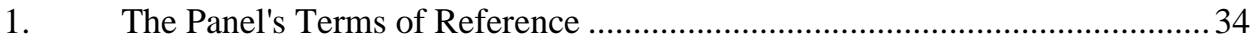

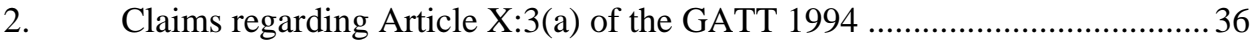

3. Conditional Appeal of the European Communities ............................................ 41

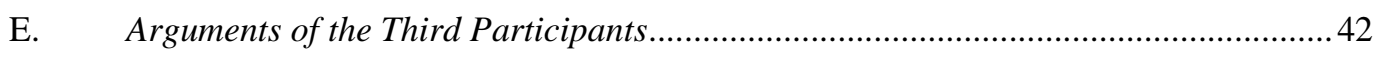

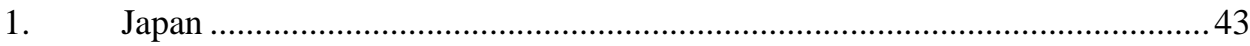

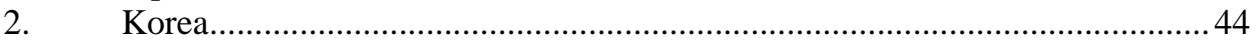

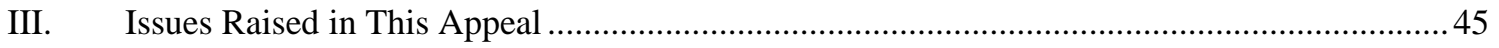

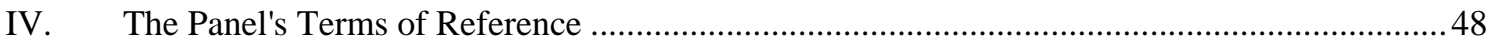

A. Interpretation of the Term "Measures at Issue" under Article 6.2 of the DSU............. 48

B. Confinement of the Measures at Issue to Areas of Customs Administration .................54

C. $\quad$ The United States' Claim Challenging the European Communities' System of Customs Administration "As a Whole" .62

1. Challenging a Legal System "Overall" or "As a Whole"..................................66

2. Whether the Panel Request Included a Challenge to the European Communities' System of Customs Administration "As a Whole" or "Overall"

3. The Panel's Finding with respect to the "Design and Structure" of the European Communities' System of Customs Administration

D. Temporal Limitations of the Panel's Terms of Reference .............................................. 71

V. Claims regarding Article X:3(a) of the GATT 1994............................................................... 76

A. Administration of European Communities Customs Law through Penalty Provisions and Audit Procedures of Member States

1. Whether the Substantive Content of a Legal Instrument May Be

Challenged under Article X:3(a) of the GATT 1994 .....................................76

2. Differences in Penalty Provisions and Audit Procedures ................................. 79

B. The Administrative Process and the Requirement of Uniformity in Article X:3(a) of the GATT 1994 
WT/DS315/AB/R

Page ii

C. The Administrative Process Leading to the Tariff Classification of Blackout Drapery Lining ........................................................................................................... 88

D. Tariff Classification of Liquid Crystal Display Flat Monitors with a Digital Video Interface

E. Administration of the Successive Sales Provision.......................................................... 100

F. Completing the Analysis with respect to the "As a Whole" Challenge of the United States under Article X:3(a) of the GATT 1994.................................................. 104

VI. The Panel's Interpretation of Article X:3(b) of the GATT 1994...........................................111

VII. Conditional Appeal of the European Communities ................................................................. 116

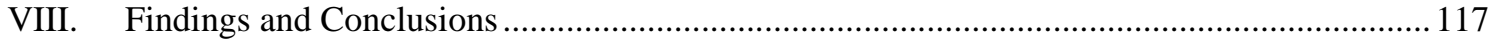

ANNEX I Notification of an Appeal by the United States

ANNEX II Notification of an Other Appeal by the European Communities

ANNEX III Request for the Establishment of a Panel by the United States 


\section{TABLE OF CASES CITED IN THIS REPORT}

\begin{tabular}{|c|c|}
\hline Short Title & Full Case Title and Citation \\
\hline Argentina - Hides and Leather & $\begin{array}{l}\text { Panel Report, Argentina-Measures Affecting the Export of Bovine Hides and } \\
\text { Import of Finished Leather, WT/DS155/R and Corr.1, adopted } 16 \text { February 2001, } \\
\text { DSR 2001:V, } 1779\end{array}$ \\
\hline Australia - Salmon & $\begin{array}{l}\text { Appellate Body Report, Australia - Measures Affecting Importation of Salmon, } \\
\text { WT/DS18/AB/R, adopted } 6 \text { November 1998, DSR 1998:VIII, } 3327\end{array}$ \\
\hline Brazil - Desiccated Coconut & $\begin{array}{l}\text { Appellate Body Report, Brazil - Measures Affecting Desiccated Coconut, } \\
\text { WT/DS22/AB/R, adopted } 20 \text { March 1997, DSR 1997:I, } 167\end{array}$ \\
\hline $\begin{array}{l}\text { Canada-Dairy } \\
\text { (Article } 21.5-\text { New Zealand } \\
\text { and US) }\end{array}$ & $\begin{array}{l}\text { Appellate Body Report, Canada - Measures Affecting the Importation of Milk } \\
\text { and the Exportation of Dairy Products - Recourse to Article } 21.5 \text { of the DSU by } \\
\text { New Zealand and the United States, WT/DS103/AB/RW, WT/DS113/AB/RW, } \\
\text { adopted } 18 \text { December 2001, DSR 2001:XIII, 6829 }\end{array}$ \\
\hline Canada - Gold Coins & $\begin{array}{l}\text { GATT Panel Report, Canada - Measures Affecting the Sale of Gold Coins, } \\
\text { L/5863, } 17 \text { September 1985, unadopted }\end{array}$ \\
\hline Chile - Price Band System & $\begin{array}{l}\text { Appellate Body Report, Chile - Price Band System and Safeguard Measures } \\
\text { Relating to Certain Agricultural Products, WT/DS207/AB/R, adopted } 23 \text { October } \\
\text { 2002, DSR 2002:VIII, } 3045\end{array}$ \\
\hline $\begin{array}{l}\text { Dominican Republic-Import } \\
\text { and Sale of Cigarettes }\end{array}$ & $\begin{array}{l}\text { Appellate Body Report, Dominican Republic - Measures Affecting the } \\
\text { Importation and Internal Sale of Cigarettes, WT/DS302/AB/R, adopted } 19 \text { May } \\
2005\end{array}$ \\
\hline EC - Bananas III & $\begin{array}{l}\text { Appellate Body Report, European Communities - Regime for the Importation, } \\
\text { Sale and Distribution of Bananas, WT/DS27/AB/R, adopted } 25 \text { September 1997, } \\
\text { DSR 1997:II, } 591\end{array}$ \\
\hline $\begin{array}{l}\text { EC-Bed Linen } \\
\text { (Article } 21.5 \text { - India) }\end{array}$ & $\begin{array}{l}\text { Appellate Body Report, European Communities - Anti-Dumping Duties on } \\
\text { Imports of Cotton-Type Bed Linen from India - Recourse to Article } 21.5 \text { of the } \\
\text { DSU by India, WT/DS141/AB/RW, adopted } 24 \text { April 2003, DSR 2003:III, } 965\end{array}$ \\
\hline EC-Chicken Cuts & $\begin{array}{l}\text { Appellate Body Report, European Communities - Customs Classification of } \\
\text { Frozen Boneless Chicken Cuts, WT/DS269/AB/R, WT/DS286/AB/R, and Corr.1, } \\
\text { adopted } 27 \text { September } 2005\end{array}$ \\
\hline EC - Computer Equipment & $\begin{array}{l}\text { Appellate Body Report, European Communities - Customs Classification of } \\
\text { Certain Computer Equipment, WT/DS62/AB/R, WT/DS67/AB/R, } \\
\text { WT/DS68/AB/R, adopted } 22 \text { June 1998, DSR 1998:V, 1851 }\end{array}$ \\
\hline EC - Computer Equipment & $\begin{array}{l}\text { Panel Report, European Communities - Customs Classification of Certain } \\
\text { Computer Equipment, WT/DS62/R, WT/DS67/R, WT/DS68/R, adopted } 22 \text { June } \\
\text { 1998, modified by Appellate Body Report, WT/DS62/AB/R, WT/DS67/AB/R, } \\
\text { WT/DS68/AB/R, DSR 1998:V, } 1891\end{array}$ \\
\hline EC-Hormones & $\begin{array}{l}\text { Appellate Body Report, EC Measures Concerning Meat and Meat Products } \\
\text { (Hormones), WT/DS26/AB/R, WT/DS48/AB/R, adopted } 13 \text { February 1998, } \\
\text { DSR 1998:I, } 135\end{array}$ \\
\hline EC-Poultry & $\begin{array}{l}\text { Appellate Body Report, European Communities - Measures Affecting the } \\
\text { Importation of Certain Poultry Products, WT/DS69/AB/R, adopted } 23 \text { July 1998, } \\
\text { DSR 1998:V, } 2031\end{array}$ \\
\hline EC-Sardines & $\begin{array}{l}\text { Appellate Body Report, European Communities - Trade Description of Sardines, } \\
\text { WT/DS231/AB/R, adopted } 23 \text { October 2002, DSR 2002:VIII, } 3359\end{array}$ \\
\hline $\begin{array}{l}\text { EC-Selected Customs } \\
\text { Matters }\end{array}$ & $\begin{array}{l}\text { Panel Report, European Communities - Selected Customs Matters, WT/DS315/R, } \\
16 \text { June } 2006\end{array}$ \\
\hline
\end{tabular}


WT/DS315/AB/R

Page iv

\begin{tabular}{|c|c|}
\hline Short Title & Full Case Title and Citation \\
\hline India - Patents (US) & $\begin{array}{l}\text { Appellate Body Report, India - Patent Protection for Pharmaceutical and } \\
\text { Agricultural Chemical Products, WT/DS50/AB/R, adopted } 16 \text { January 1998, } \\
\text { DSR 1998:I, } 9\end{array}$ \\
\hline Japan-Apples & $\begin{array}{l}\text { Appellate Body Report, Japan - Measures Affecting the Importation of Apples, } \\
\text { WT/DS245/AB/R, adopted } 10 \text { December 2003, DSR 2003:IX, } 4391\end{array}$ \\
\hline Japan - Film & $\begin{array}{l}\text { Panel Report, Japan - Measures Affecting Consumer Photographic Film and } \\
\text { Paper, WT/DS44/R, adopted } 22 \text { April 1998, DSR 1998:IV, } 1179\end{array}$ \\
\hline Korea - Dairy & $\begin{array}{l}\text { Appellate Body Report, Korea - Definitive Safeguard Measure on Imports of } \\
\text { Certain Dairy Products, WT/DS98/AB/R, adopted } 12 \text { January 2000, } \\
\text { DSR 2000:I, } 3\end{array}$ \\
\hline $\begin{array}{l}\text { Mexico-Anti-Dumping } \\
\text { Measures on Rice }\end{array}$ & $\begin{array}{l}\text { Appellate Body Report, Mexico - Definitive Anti-Dumping Measures on Beef and } \\
\text { Rice, Complaint with Respect to Rice, WT/DS295/AB/R, adopted } 20 \text { December } \\
2005\end{array}$ \\
\hline Thailand-H-Beams & $\begin{array}{l}\text { Appellate Body Report, Thailand - Anti-Dumping Duties on Angles, Shapes and } \\
\text { Sections of Iron or Non-Alloy Steel and H-Beams from Poland, } \\
\text { WT/DS122/AB/R, adopted } 5 \text { April 2001, DSR 2001:VII, } 2701\end{array}$ \\
\hline US - Carbon Steel & $\begin{array}{l}\text { Appellate Body Report, United States - Countervailing Duties on } \\
\text { Certain Corrosion-Resistant Carbon Steel Flat Products from Germany, } \\
\text { WT/DS213/AB/R and Corr.1, adopted 19 December 2002, DSR 2002:IX, } 3779\end{array}$ \\
\hline $\begin{array}{l}\text { US - Corrosion-Resistant } \\
\text { Steel Sunset Review }\end{array}$ & $\begin{array}{l}\text { Appellate Body Report, United States - Sunset Review of Anti-Dumping Duties } \\
\text { on Corrosion-Resistant Carbon Steel Flat Products from Japan, } \\
\text { WT/DS244/AB/R, adopted } 9 \text { January 2004, DSR 2004:I, } 3\end{array}$ \\
\hline US - Cotton Yarn & $\begin{array}{l}\text { Appellate Body Report, United States - Transitional Safeguard Measure on } \\
\text { Combed Cotton Yarn from Pakistan, WT/DS192/AB/R, adopted } 5 \text { November } \\
\text { 2001, DSR 2001:XII, } 6027\end{array}$ \\
\hline $\begin{array}{l}\text { US - FSC } \\
\text { (Article } 21.5-\text { EC II) }\end{array}$ & $\begin{array}{l}\text { Appellate Body Report, United States - Tax Treatment for "Foreign Sales } \\
\text { Corporations" - Second Recourse to Article } 21.5 \text { of the DSU by the European } \\
\text { Communities, WT/DS108/AB/RW2, adopted } 14 \text { March } 2006\end{array}$ \\
\hline US - Hot-Rolled Steel & $\begin{array}{l}\text { Panel Report, United States - Anti-Dumping Measures on Certain Hot-Rolled } \\
\text { Steel Products from Japan, WT/DS184/R, adopted 23 August } 2001 \text { modified by } \\
\text { Appellate Body Report, WT/DS184/AB/R, DSR 2001:X, } 4769\end{array}$ \\
\hline $\begin{array}{l}\text { US - Oil Country Tubular } \\
\text { Goods Sunset Reviews }\end{array}$ & $\begin{array}{l}\text { Appellate Body Report, United States - Sunset Reviews of Anti-Dumping } \\
\text { Measures on Oil Country Tubular Goods from Argentina, WT/DS268/AB/R, } \\
\text { adopted } 17 \text { December } 2004\end{array}$ \\
\hline $\begin{array}{l}\text { US - Section } 211 \\
\text { Appropriations Act }\end{array}$ & $\begin{array}{l}\text { Appellate Body Report, United States - Section } 211 \text { Omnibus Appropriations } \\
\text { Act of 1998, WT/DS176/AB/R, adopted } 1 \text { February 2002, DSR 2002:II, } 589\end{array}$ \\
\hline US - Upland Cotton & $\begin{array}{l}\text { Appellate Body Report, United States - Subsidies on Upland Cotton, } \\
\text { WT/DS267/AB/R, adopted } 21 \text { March } 2005\end{array}$ \\
\hline US - Upland Cotton & $\begin{array}{l}\text { Panel Report, United States - Subsidies on Upland Cotton, WT/DS267/R, and } \\
\text { Corr.1, adopted } 21 \text { March 2005, modified by Appellate Body Report, } \\
\text { WT/DS267/AB/R }\end{array}$ \\
\hline US - Wool Shirts and Blouses & $\begin{array}{l}\text { Appellate Body Report, United States - Measure Affecting Imports of Woven } \\
\text { Wool Shirts and Blouses from India, WT/DS33/AB/R and Corr.1, adopted } \\
23 \text { May 1997, DSR 1997:I, } 323\end{array}$ \\
\hline US - Zeroing (EC) & $\begin{array}{l}\text { Appellate Body Report, United States - Laws, Regulations and Methodology for } \\
\text { Calculating Dumping Margins ("Zeroing"), WT/DS294/AB/R, adopted } 9 \text { May } \\
2006\end{array}$ \\
\hline
\end{tabular}




\section{LIST OF ABBREVIATIONS USED IN THIS REPORT}

\begin{tabular}{|c|c|}
\hline Abbreviation & Description \\
\hline BTI & Binding Tariff Information \\
\hline CFI & Court of First Instance of the European Communities \\
\hline Common Customs Tariff & $\begin{array}{l}\text { Council Regulation (EEC) No. 2658/87 of } 23 \text { July } 1987 \text { on the tariff and } \\
\text { statistical nomenclature and on the Common Customs Tariff }\end{array}$ \\
\hline Community Customs Code & $\begin{array}{l}\text { Council Regulation (EEC) No. 2913/92 of } 12 \text { October } 1992 \text { establishing } \\
\text { the Community Customs Code }\end{array}$ \\
\hline Court of Auditors Report & $\begin{array}{l}\text { Court of Auditors, Special Report No. } 23 / 2000 \text { concerning valuation of } \\
\text { imported goods for customs purposes (customs valuation), together with } \\
\text { the Commission's replies, reproduced in Official Journal of the } \\
\text { European Communities, C Series, No. 84, pp. 1-18 (14 March 2001) }\end{array}$ \\
\hline DSB & Dispute Settlement Body \\
\hline DSU & $\begin{array}{l}\text { Understanding on Rules and Procedures Governing the Settlement of } \\
\text { Disputes }\end{array}$ \\
\hline DVI & digital video interface \\
\hline EBTI & European Binding Tariff Information \\
\hline EC Regulation 2171/2005 & $\begin{array}{l}\text { Commission Regulation (EC) No. 2171/2005 of } 23 \text { December } 2005 \\
\text { concerning the classification of certain goods in the Combined } \\
\text { Nomenclature }\end{array}$ \\
\hline EC Treaty & Treaty Establishing the European Communities \\
\hline ECJ & Court of Justice of the European Communities \\
\hline GATT 1994 & General Agreement on Tariffs and Trade 1994 \\
\hline Implementing Regulation & $\begin{array}{l}\text { Commission Regulation (EEC) No. 2454/93 of } 2 \text { July } 1993 \text { laying } \\
\text { down provisions for the implementation of Council Regulation (EEC) } \\
\text { No. 2913/92 of } 12 \text { October } 1992 \text { establishing the Community Customs } \\
\text { Code }\end{array}$ \\
\hline LCD & liquid crystal display \\
\hline Panel Report & Panel Report, EC - Selected Customs Matters \\
\hline Panel request & $\begin{array}{l}\text { European Communities - Selected Customs Matters, Request for the } \\
\text { Establishment of a Panel by the United States, WT/DS315/8, 14 January } \\
2005\end{array}$ \\
\hline TARIC & $\begin{array}{l}\text { Integrated Tariff of the European Communities established by Council } \\
\text { Regulation (EEC) No. 2658/87 of } 23 \text { July } 1987 \text { on the tariff and } \\
\text { statistical nomenclature and on the Common Customs Tariff }\end{array}$ \\
\hline Working Procedures & $\begin{array}{l}\text { Working Procedures for Appellate Review, WT/AB/WP/5, } 4 \text { January } \\
2005\end{array}$ \\
\hline WTO & World Trade Organization \\
\hline WTO Agreement & Marrakesh Agreement Establishing the World Trade Organization \\
\hline
\end{tabular}





\section{WORLD TRADE ORGANIZATION}

APPELLATE BODY

\section{European Communities - Selected Customs Matters}

United States, Appellant/Appellee

European Communities, Appellant/Appellee

Argentina, Third Participant

Australia, Third Participant

Brazil, Third Participant

China, Third Participant

Hong Kong, China, Third Participant

India, Third Participant

Japan, Third Participant

Korea, Third Participant

Separate Customs Territory of Taiwan, Penghu, Kinmen, and Matsu, Third Participant
AB-2006-4

Present:

Ganesan, Presiding Member

Janow, Member

Taniguchi, Member

\section{Introduction}

1. The United States and the European Communities each appeal certain issues of law and legal interpretations developed in the Panel Report, European Communities - Selected Customs Matters (the "Panel Report"). ${ }^{1}$ The Panel was established to consider a complaint by the United States concerning the European Communities' system of customs administration under Articles X:3(a) and X:3(b) of the General Agreement on Tariffs and Trade 1994 (the "GATT 1994").

2. Before the Panel, the United States claimed that the European Communities administers the following instruments of its customs law in a non-uniform manner, in violation of Article X:3(a) of the GATT 1994:

- Council Regulation (EEC) No. 2913/92 of 12 October 1992 establishing the Community Customs Code, including all annexes thereto, as amended (the "Community Customs Code");

- Commission Regulation (EEC) No. 2454/93 of 2 July 1993 laying down provisions for the implementation of Council Regulation (EEC) No. 2913/92 of 12 October 1992 establishing the Community Customs Code, including all annexes thereto, as amended (the "Implementing Regulation");

\footnotetext{
${ }^{1} \mathrm{WT} / \mathrm{DS} 315 / \mathrm{R}, 16$ June 2006.
} 
WT/DS315/AB/R

Page 2

- Council Regulation (EEC) No. 2658/87 of 23 July 1987 on the tariff and statistical nomenclature and on the Common Customs Tariff, including all annexes thereto, as amended (the "Common Customs Tariff");

- the Integrated Tariff of the European Communities established by virtue of Article 2 of Council Regulation (EEC) No. 2658/87 of 23 July 1987 on the tariff and statistical nomenclature and on the Common Customs Tariff, including all annexes thereto, as amended (the "TARIC"); and

- for each of the above laws and regulations, all amendments, "implementing measures and other related measures". ${ }^{2}$

3. The United States submitted that various instances of alleged non-uniform administration of European Communities customs law illustrate that the European Communities' system of customs administration as a whole is inconsistent with the requirement of uniform administration contained in Article X:3(a) of the GATT 1994. In addition, the United States claimed that the European Communities does not provide for the prompt review and correction of administrative action relating to customs matters as required by Article X:3(b) of the GATT $1994 .^{3}$

4. In the Panel Report, circulated to Members of the World Trade Organization (the "WTO") on 16 June 2006, the Panel concluded that its terms of reference authorized it to consider only "the manner of administration by the national customs authorities of the member States of the Community Customs Code, the Implementing Regulation, the Common Customs Tariff, the TARIC and related measures in the areas of customs administration specifically identified in the United States' request for establishment of a panel." ${ }^{4}$ These areas of customs administration were "the classification and valuation of goods, procedures for the classification and valuation of goods, procedures for the entry and release of goods, procedures for auditing entry statements after goods are released into free circulation, penalties and procedures regarding the imposition of penalties for violation of customs rules and record-keeping requirements". ${ }^{5}$ The Panel held that it was "authorized to examine particular cases or instances of administration of the Community Customs Code, the Implementing Regulation,

\footnotetext{
${ }^{2}$ Request for the Establishment of a Panel by the United States, WT/DS315/8, 14 January 2005 (attached as Annex III to this Report), p. 1; Panel Report, para. 2.1. These laws and regulations are contained in Exhibits US-5, US-6, EC-16, and US-7, respectively, submitted by the United States and the European Communities to the Panel.

${ }^{3}$ Panel Report, paras. 2.1 and 7.492.

${ }^{4}$ Ibid., para. 7.64.

${ }^{5}$ Ibid., para. 7.33.
} 
the Common Customs Tariff and the TARIC and related measures in those areas of customs administration specifically identified in the United States' request". 6

5. The Panel found that it was "precluded from considering 'as such' challenges of the design and structure of the [European Communities'] system of customs administration as a whole, and also the design and structure of the [European Communities'] system in the areas of customs administration ... specifically identified in the United States' request for the establishment of a panel." ${ }^{7}$ However, at the conclusion of its analysis of the United States' claim under Article X:3(a) of the GATT 1994, the Panel observed that, even if it were authorized by its terms of reference to make findings on the design and structure of the European Communities' system of customs administration "as such", the United States had not demonstrated that the design and structure of the European Communities' system of customs administration, including components thereof, necessarily results in a violation of Article X:3(a). According to the Panel, the United States merely referred to "a number of apparently random instances of alleged violation of Article X:3(a) ..., without demonstrating ... that those examples are symptomatic and representative of underlying structural deficiencies in the [European Communities'] system of customs administration." ${ }^{8}$

6. The Panel examined individual instances of alleged non-uniform administration of European Communities' customs law in three different areas: customs classification, customs valuation, and customs procedures. ${ }^{9}$ First, the Panel examined the United States' claims alleging non-uniform administration in the area of customs classification. The Panel found no violation of Article X:3(a) of the GATT 1994 with respect to the tariff classification of network cards for personal computers ${ }^{10}$ and no violation regarding the tariff classification of drip irrigation products. ${ }^{11}$ The Panel found, however, that the administrative process leading to decisions on tariff classification of blackout drapery lining by German customs authorities amounts to non-uniform administration and therefore constitutes a violation of Article X:3(a) of the GATT 1994. ${ }^{12}$ The Panel also found a violation of the same

\footnotetext{
${ }^{6}$ Panel Report, para. 7.64.

${ }^{7}$ Ibid.

${ }^{8}$ Ibid., para. 7.490 .

${ }^{9}$ The Panel found that Article 221 of the Community Customs Code, which is entitled "Recovery of the amount of the Customs Debt", was not covered by any of the areas of customs administration specifically identified in the United States' request for the establishment of a panel and therefore fell outside the Panel's terms of reference. (Ibid., para. 7.487)

${ }^{10}$ Ibid., para. 7.207.

${ }^{11}$ Ibid., para. 7.218.

${ }^{12}$ Ibid., para. 7.276.
} 
WT/DS315/AB/R

Page 4

provision with respect to the tariff classification of liquid crystal display ("LCD") monitors with digital video interface ("DVI"). ${ }^{13}$

7. The Panel also found that the United States had not proved any violation of Article X:3(a) of the GATT 1994 with respect to: (i) the tariff classification of unisex articles or shorts ${ }^{14}$; (ii) the failure of customs authorities in one member State to treat Binding Tariff Information ("BTI") issued in other member States as binding ${ }^{15}$; (iii) the refusal to withdraw the revocation of BTI by the United Kingdom's customs authorities with respect to the tariff classification of the Sony PlayStation2 in the context of the Sony PlayStation 2 case $^{16}$; or (iv) the interpretation and application of the amended Explanatory Notes to the Common Customs Tariff concerning camcorders in the context of the Camcorders case. $^{17}$

8. Secondly, the Panel examined individual instances of customs administration in the area of customs valuation. The Panel found that the administration of Article 147(1) of the Implementing Regulation (the "successive sales provision") amounts to a violation of Article X:3(a), because some member States impose a "form of prior approval" requirement while others do not. ${ }^{18}$ The Panel found no violation with respect to the administration of Article 29(3)(a) of the Community Customs Code concerning vehicle repair costs covered under warranty. ${ }^{19}$ The Panel found that the United States had not proved that differences among member States regarding the manner in which royalties are apportioned to the customs value of identical goods imported by the same company according to Article 32(1)(c) of the Community Customs Code amount to a violation of Article X:3(a) of the GATT 1994. ${ }^{20}$ The Panel also found that the United States had not proved that the administration of Article 29 of the Community Customs Code and Article 143(1)(e) of the Implementing Regulation concerning the circumstances in which parties are to be treated as "related" for customs valuation purposes is non-uniform within the meaning of Article X:3(a) of the GATT $1994 .^{21}$

\footnotetext{
${ }^{13}$ Panel Report, para. 7.305.

${ }^{14}$ Ibid., para. 7.228.

${ }^{15}$ Ibid., para. 7.329 .

${ }^{16}$ Ibid., para. 7.343 (referring to Sony Computer Entertainment Europe Ltd. v. Commissioners of
} Customs and Excise, Judgment of the High Court of Justice, Chancery Division (2005), EWHC 1644 (Ch) (Exhibit US-70 submitted by the United States to the Panel)).

${ }^{17}$ Ibid., para. 7.354 (referring to Explanatory Notes to the Combined Nomenclature of the European Communities, Official Journal of the European Communities (13 July 2000), 316 (Exhibit US-62 submitted by the United States to the Panel)).

${ }^{18}$ Ibid., para. 7.385 .

${ }^{19}$ Ibid., para. 7.403 .

${ }^{20}$ Ibid., para. 7.371 .

${ }^{21}$ Ibid., para. 7.418. 
9. Thirdly, the Panel examined individual instances of customs administration in the area of customs procedure. The Panel found no violation of Article X:3(a) with respect to the manner of administration of Article 78(2) of the Community Customs Code, which allows customs authorities to conduct audits following release of goods for free circulation within the European Communities. ${ }^{22}$ The Panel also found no violation of Article X:3(a) with respect to "the substantive differences in penalty laws between member States" on the ground that "the substantive content of penalty laws ... cannot be viewed as acts of administration" under Article X:1. ${ }^{23}$ The Panel further found that the United States had not proved that "the manner of administration of Article 133 of the Community Customs Code and Articles 502(3) and 552 of the Implementing Regulation regarding processing under customs control is non-uniform among member States in violation of Article X:3(a) of the GATT 1994."24 Finally, the Panel found that "the United States ha[d] not proved that Articles 263-267 of the Implementing Regulation are administered in a non-uniform manner in violation of Article X:3(a) of the GATT 1994." ${ }^{25}$

10. Finally, with respect to the United States' claim of violation of Article X:3(b) of the GATT 1994, the Panel found that the European Communities does not violate the obligation to provide prompt review and correction of administrative action relating to customs matters "merely because the decisions regarding review of administrative action relating to customs matters ... do not apply to all agencies in the [European Communities] and do not have effect throughout the territory of the European Communities". ${ }^{26}$

11. The Panel therefore recommended:

... that the Dispute Settlement Body request the European Communities to bring itself into conformity with respect to:

(a)

the administration of the Common Custom[s] Tariff regarding the administrative process leading to the tariff classification of blackout drapery lining;

(b) the administration of the Common Customs Tariff regarding the tariff classification of liquid crystal display monitors with digital video interface;

\footnotetext{
${ }^{22}$ Panel Report, para. 7.434.

${ }^{23}$ Ibid., para. 7.444 .

${ }^{24}$ Ibid., para. 7.465.

${ }^{25}$ Ibid., para. 7.477.

${ }^{26}$ Ibid., para. 7.556.
} 
WT/DS315/AB/R

Page 6

(c) the administration of Article 147(1) of the Implementing Regulation regarding the imposition by customs authorities in some member States of a form of prior approval with respect to the successive sales provision in the context of customs valuation. ${ }^{27}$

12. On 14 August 2006, the United States notified the Dispute Settlement Body (the "DSB") of its intention to appeal certain issues of law covered in the Panel Report and certain legal interpretations developed by the Panel, pursuant to Article 16.4 of the Understanding on Rules and Procedures Governing the Settlement of Disputes (the "DSU"), and filed a Notice of Appeal ${ }^{28}$ pursuant to Rule 20 of the Working Procedures for Appellate Review (the "Working Procedures"). ${ }^{29}$ On 21 August 2006, the United States filed an appellant's submission. ${ }^{30}$ On 28 August 2006, the European Communities notified the DSB of its intention to appeal certain issues of law covered in the Panel Report and certain legal interpretations developed by the Panel, pursuant to Article 16.4 of the DSU, and filed a Notice of Other Appeal ${ }^{31}$ pursuant to Rule 23(1) and (2) of the Working Procedures. On 29 August 2006, the European Communities filed an other appellant's submission. ${ }^{32}$ On 11 September 2006, the United States and the European Communities each filed an appellee's submission. ${ }^{33}$ On the same day, Japan and Korea each filed a third participant's submission ${ }^{34}$, and Argentina, Australia, Brazil, China, Hong Kong, China, India, and the Separate Customs Territory of Taiwan, Penghu, Kinmen, and Matsu each notified the Appellate Body Secretariat of its intention to appear at the oral hearing as a third participant. ${ }^{35}$

13. By letter dated 15 September 2006, Japan requested authorization from the Appellate Body Division hearing the appeal to correct a "clerical error" in its third participant's submission, pursuant to Rule 18(5) of the Working Procedures. On 18 September 2006, the Division invited all participants and third participants to comment on Japan's request. None of the participants or third participants objected to Japan's request. On 20 September 2006, the Division authorized Japan, pursuant to Rule 18(5), to correct the clerical error in its third participant's submission.

\footnotetext{
${ }^{27}$ Panel Report, para. 8.2.

${ }^{28} \mathrm{WT} / \mathrm{DS} 315 / 11$ (attached as Annex I to this Report).

${ }^{29} \mathrm{WT} / \mathrm{AB} / \mathrm{WP} / 5,4$ January 2005.

${ }^{30}$ Pursuant to Rule 21(1) of the Working Procedures.

${ }^{31}$ WT/DS315/12 (attached as Annex II to this Report).

${ }^{32}$ Pursuant to Rule 23(3) of the Working Procedures.

${ }^{33}$ Pursuant to Rules 22 and 23(4) of the Working Procedures.

${ }^{34}$ Pursuant to Rule 24(1) of the Working Procedures.

${ }^{35}$ Pursuant to Rule 24(2) of the Working Procedures.
} 
14. The oral hearing in this appeal was held on 28 and 29 September 2006. The participants and the third participants presented oral arguments (with the exception of Argentina, Brazil, Hong Kong, China, India, Korea, and the Separate Customs Territory of Taiwan, Penghu, Kinmen, and Matsu) and responded to questions posed by the Members of the Division hearing the appeal.

\section{Arguments of the Participants and the Third Participants}

\section{A. Claims of Error by the United States - Appellant}

\section{The Panel's Terms of Reference}

15. The United States requests the Appellate Body to reverse the findings of the Panel concerning its terms of reference. According to the United States, the Panel erred in three respects: first, in finding that, under Article 6.2 of the DSU, the measure at issue must be the "manner of administration" when a claim is made under Article X:3(a) of the GATT 1994; secondly, in finding that the specific measure at issue in this dispute was confined to the six areas of customs administration identified in the third paragraph of the request for the establishment of a panel by the United States (the "panel request") ${ }^{36}$; and finally, in concluding that, due to the wording and content of the panel request, the United States was precluded from challenging the European Communities' system of customs administration "as a whole".

\section{(a) The "Measures at Issue" for Purposes of a Claim under Article X:3(a)} of the GATT 1994

16. According to the United States, the Panel erroneously found that, when a violation of Article X:3(a) of the GATT 1994 is alleged, the measure to be identified in the panel request must be a "manner of administration". ${ }^{37}$ For the United States, in making this finding, the Panel relied primarily on what it described as "an inter-linkage between the reference to the term 'measure' in Article 19.1 of the DSU and to the term 'measures at issue' in Article 6.2 of the DSU." ${ }^{38}$ The Panel also reasoned that, under Article 19.1 of the DSU, a Member breaching Article X:3(a) of the GATT 1994 would be required "to alter the manner in which the relevant laws, regulations, decisions and/or rulings are being administered in order to abide by that recommendation." ${ }^{39}$

\footnotetext{
${ }^{36}$ Request for the Establishment of a Panel by the United States, WT/DS315/8 (attached as Annex III to this Report).

${ }^{37}$ Panel Report, para. 7.20.

${ }^{38}$ United States' appellant's submission, para. 45 (referring to Panel Report, para. 7.14).

${ }^{39}$ Ibid., para. 46 (referring to Panel Report para. 7.21). (original emphasis)
} 
WT/DS315/AB/R

Page 8

17. The United States contends that this reasoning of the Panel is flawed because a "manner of administration" is not a "measure" but, rather, a description of how a measure operates. ${ }^{40}$ The United States adds that this approach blurs the distinction between measures and claims. ${ }^{41}$ By finding the "manner of administration" to be the measure at issue, the Panel confused the measure at issue in an Article X:3(a) dispute with the obligation under that provision. The United States also argues that the Panel's reasoning leads to illogical consequences for complaints under other WTO provisions as well, because, under such an approach, the measure at issue is not "distinguishable" from the legal basis of the complaint for purposes of Article 6.2 of the DSU. ${ }^{42}$ Regarding the "inter-linkage" between Articles 6.2 and 19.1 of the DSU identified by the Panel, the United States points out that the mere fact that a breach of Article X:3(a) may be removed by changing a law's administration cannot be a basis for concluding that the law is not the measure at issue. ${ }^{43}$ The United States argues that, although Article 19.1 of the DSU contemplates a recommendation that a Member bring a measure into conformity with a covered agreement, it is silent as to how this is to be done. ${ }^{44}$

(b) Confinement of the Measures at Issue to Certain Areas of Customs Administration

18. The United States contends that the Panel erred in confining the specific measures at issue to the areas of customs administration indicated in the panel request, because the Panel failed to construe the panel request "as a whole". The United States also argues that the Panel confused arguments, on the one hand, with measures and claims, on the other hand. ${ }^{45}$ For the United States, had the Panel construed the panel request "as a whole", it could not have avoided the conclusion that, first, the specific measures at issue were the Community Customs Code, the Implementing Regulation, the Common Customs Tariff, the TARIC, and, for each of these measures, all amendments, "implementing measures, and other related measures"; and, secondly, that the legal basis of the complaint was the administration of those measures in a manner inconsistent with Article X:3(a) of the GATT $1994{ }^{46}$ The United States emphasizes that the list of areas of customs administration provided in the panel request was only illustrative, aimed to give an indication of the argument underlying the United States' claim, and did not constitute the claim itself or the specific measures at

\footnotetext{
${ }^{40}$ United States' appellant's submission, para. 47.

${ }^{41}$ Ibid.

${ }^{42}$ Ibid., para. 49.

${ }^{43}$ Ibid., para. 48.

${ }^{44}$ Ibid.

${ }^{45}$ Ibid., para. 52.

${ }^{46}$ Ibid., paras. 54-55.
} 
issue. ${ }^{47}$ According to the United States, the Panel read individual phrases in the panel request in isolation, focusing on "particular text ... taken out of its context". ${ }^{48}$ The United States maintains that the Panel's characterization of the illustrative list as a specification of the measures at issue "ignored the introduction to the list, which stated that '[l]ack of uniform, impartial and reasonable administration of the above-identified measures is manifest in differences among member States in a number of areas, including, but not limited to, the following."'49

19. The United States also points out that the Panel gave no consideration to the fact that the request included a claim that the absence of mechanisms or institutions to secure uniform administration in the European Communities' system of customs administration "as a whole" results in a breach of Article X:3(a). ${ }^{50}$ For the United States, the Panel missed the fundamental point that "nowhere in the system as a whole ... are there mechanisms or institutions which achieve the uniformity in administration which Article X:3(a) requires". ${ }^{51}$ With respect to the analogy made by the Panel to the EC-Computer Equipment dispute, the United States considers that the Panel erred because, in EC - Computer Equipment, the scope of the measures at issue depended on the identity of the products subject to the measures; also, the claim put forward in that case was not "systemic" and did not relate to the system "as a whole". ${ }^{52}$

20. The United States considers that the Panel's approach led to a confusion of claims and measures, on the one hand, with arguments, on the other hand. The United States does not believe it was required to list the areas in which the manner of administration of the specific measure at issue was inconsistent with Article X:3(a); however, in the view of the United States, such a list made the panel request more transparent, in that it anticipated certain arguments the United States would make in its submissions and statements to substantiate its claims. For the United States, rather than understanding the discussion in the panel request as intended, the Panel mischaracterized it as "an elaboration of what it understood to be the measure at issue" ${ }^{53}$

\footnotetext{
${ }^{47}$ United States' appellant's submission, para. 57.

${ }^{48}$ Ibid., para. 58.

${ }^{49}$ Ibid., para. 59.

${ }^{50}$ Ibid., para. 61.

${ }^{51}$ Ibid.

${ }^{52}$ Ibid., para. 62.

${ }^{53}$ Ibid., para. 66.
} 
WT/DS315/AB/R

Page 10

(c) Challenging the European Communities' System of Customs Administration "As a Whole"

21. The United States contends that the Panel erred by construing the panel request to exclude a claim that the European Communities' system of customs administration "as a whole" results in nonuniform administration of European Communities customs law in breach of Article X:3(a) of the GATT 1994. For the United States, the Panel erred in considering that, in order to challenge the European Communities' system of customs administration "as a whole", the United States would have had to list separately "each and every area of customs administration". ${ }^{54}$ This aspect of the Panel's reasoning, the United States argues, would make it "virtually impossible" to challenge a responding Member's system "as a whole" or overall. ${ }^{55}$

22. The United States maintains that the panel request made it clear that its claim related to the European Communities' system of customs administration "as a whole", because it identified the measures that constitute the main instruments of European Communities customs legislation and addressed the manner of administration of these instruments collectively. ${ }^{56}$ For the United States, the heart of the problem is that "the [European Communities] administers its customs law through 25 separate, independent customs authorities and does not provide any institution or mechanism to reconcile divergences automatically and as a matter of right when they occur." ${ }^{57}$ The United States underlines that, throughout the panel request, the measures at issue were discussed collectively, and that this "is precisely what one would expect in a panel request challenging a system of customs administration as a whole." ${ }^{\text {58 }}$

23. According to the United States, the Panel's interpretation of the panel request rested on its view that the word "manner", as used in the panel request, was not related to "the design and structure of something"59, and the Panel assumed that a challenge to the design and structure of the European Communities' system of customs administration must refer to "actions taken and/or procedures and institutions existing at the [European Communities] level". ${ }^{60}$ For the United States, these aspects of the Panel's reasoning are problematic; given that the very essence of the Article X:3(a) obligation is the "manner" of administration of certain types of measures, it would be "illogical to assume that [the] use of the word 'manner' in a claim involving Article X:3(a) of the GATT 1994 necessarily suggests

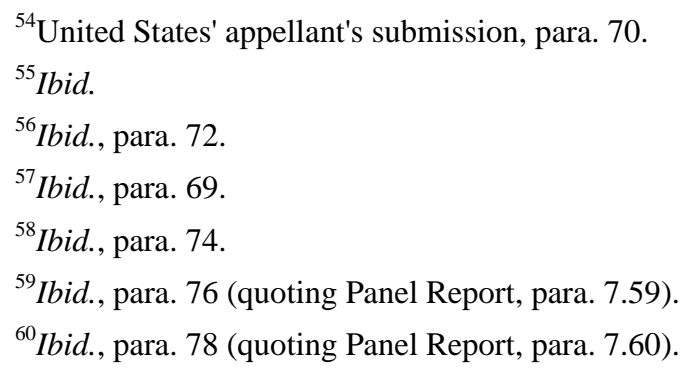


that the claim does not relate to a Member's system of customs administration as a whole."61 Furthermore, the United States is of the view that, because "the defining characteristic of the design and structure of the [European Communities'] system of customs administration ... is the absence of procedures and institutions" at the European Communities level, a challenge to the design and structure of this system must necessarily address administration undertaken by member State customs authorities. $^{62}$

24. The United States considers that it clearly articulated a challenge to the European Communities' system of customs administration in the panel request. ${ }^{63}$ The United States submits that the absence of an explicit reference to the terms "as such" or "per se" in the panel request does not preclude a claim with respect to the European Communities' system of customs administration "as a whole". What is important, the United States argues, is that the responding party be aware of the claim against it so that its ability to defend itself is not prejudiced. ${ }^{64}$ For the United States, it is clear from statements by the European Communities at meetings of the DSB, and from the European Communities' submissions and statements during the Panel proceedings, that the European Communities was aware that the United States had made a claim with respect to the European Communities' system of customs administration "as a whole". ${ }^{65}$ For the United States, the "consistent articulation" by the United States throughout the Panel proceedings of a claim concerning the European Communities' system of customs administration "as a whole" is "a strong indication [that the European Communities] did not suffer any prejudice on account of any lack of clarity in the panel request". ${ }^{66}$

\section{2. $\quad$ Claims regarding Article X:3(a) of the GATT 1994}

(a) The Panel's Interpretation of the Term "Administer" in Article X:3(a) of the GATT 1994

25. The United States submits that the Panel erred in its interpretation and application of the term "administer" in Article X:3(a) of the GATT 1994, and its consequent treatment of differences in penalty provisions and audit procedures among the member States of the European Communities. ${ }^{67}$ The Panel itself noted that the existence of substantive differences in penalty provisions and audit

\footnotetext{
${ }^{61}$ United States' appellant's submission, para. 77.

${ }^{62}$ Ibid., para. 78. (original emphasis)

${ }^{63}$ Ibid., para. 82.

${ }^{64}$ Ibid., paras. 83-84.

${ }^{65}$ Ibid., paras. 86-87, 88-91, and 93-97.

${ }^{66}$ Ibid., para. 98 (quoting Appellate Body Report, Thailand - H-Beams, para. 95).

${ }^{67}$ Ibid., para. 109. See also Panel Report, paras. 7.444, 8.1(d)(ii), 7.434, and 8.1(d)(i), respectively.
} 
WT/DS315/AB/R

Page 12

procedures among member States is not disputed between the parties. ${ }^{68}$ In the United States' view, these divergences in laws among the member States, in and of themselves, lead to non-uniform administration of European Communities customs law in breach of Article X:3(a). ${ }^{69}$ The United States asserts that the arguments it made with respect to the Panel's approach to divergences in penalty laws apply equally with respect to the Panel's approach to audit procedures. ${ }^{70}$

26. The United States agrees with the Panel that measures are administered when they are "put into practical effect". ${ }^{71}$ The United States contends that penalty and audit regimes put the measures subject to those regimes into practical effect because they encourage compliance with, and deter breaches of, those measures. $^{72}$ The United States submits that the different penalty regimes put European Communities customs law into effect differently among the member States and that this amounts to a failure by the European Communities to administer its customs law in a uniform manner. ${ }^{73}$

27. Further, the United States refers to the Panel's finding that "the substantive content of penalty laws of the member States used to enforce [European Communities] customs law cannot be viewed as acts of administration". ${ }^{74}$ The United States contends that a breach of Article X:3(a) can be substantiated not only by particular "acts of administration", but also by the laws themselves. According to the United States, if divergences between individual acts of administration (for example, individual impositions of penalties for identical breaches of European Communities customs law) constitute non-uniform administration, then, a fortiori, divergences in the penalty provisions that govern the individual acts of administration carried out by different customs authorities must also constitute non-uniform administration.

28. The United States alleges that the Panel's findings in the present case are inconsistent with the findings regarding Article X:3(a) of the GATT 1994 made by the panel in Argentina - Hides and Leather. In the view of the United States, the Panel should have recognized the distinction that the panel in Argentina - Hides and Leather recognized between measures of general application whose

\footnotetext{
${ }^{68}$ United States' appellant's submission, para. 109 (referring to Panel Report, para. 7.444).

${ }^{69}$ Ibid., para. 110.

${ }^{70}$ Ibid., paras. 111 and 150 .

${ }^{71}$ Ibid., para. 118 (quoting Panel Report, para 7.104).

${ }^{72}$ Ibid., para. 120 .

${ }^{73}$ Ibid., paras. 121 and 123.

${ }^{74}$ Panel Report, para. 7.444 (quoted in United States' appellant's submission, para. 113).
} 
manner of administration is at issue under Article X:3(a), and measures of general application that put the measures at issue into practical effect. ${ }^{75}$

29. Furthermore, the United States submits that the Panel's reasoning concerning penalty laws is contradicted by other parts of the Panel Report. In the United States' view, the Panel recognized that a measure of general application may be put into practical effect through an instrument that happens also to be a measure of general application, and that it is appropriate to consider the substance of that instrument to determine how the measure at issue is being administered. In this respect, the United States mentions two aspects of the Panel Report: first, with respect to the tariff classification of blackout drapery lining, the Panel referred to the fact that one customs authority (in Germany) relied on an interpretative aid not relied on by customs authorities of other member States; and secondly, with respect to LCD monitors with DVI, the Panel referred to the substance of a Tariff Notice issued by the United Kingdom customs authority and a decree issued by the Dutch customs authority as showing a lack of uniform administration of the European Communities classification rules at issue. The United States submits that the Panel itself considered the substance of a measure of general application concerning blackout drapery lining and LCD monitors with DVI to determine how the Common Customs Tariff was being administered. In the United States' view, the same rationale should have been applied to the administration of penalty provisions. ${ }^{76}$

30. With respect to the Panel's finding concerning differences in audit procedures among the member States of the European Communities, the United States submits that the Panel erred in limiting the scope of the claim to the non-uniform administration of Article 78(2) of the Community Customs Code. The United States submits further that, even if the Panel had been correct in limiting its examination to Article 78(2) of the Community Customs Code, the Panel's reasoning was based on an incorrect interpretation of the term "administer" in Article X:3(a) of the GATT 1994. The United States contends that the error in the Panel's analysis is essentially the same as the error in its analysis of penalty provisions. Therefore, the United States considers the arguments it presented in the context of penalty provisions equally valid in the context of audit proceedings. ${ }^{77}$

31. In the event that the Appellate Body reverses the Panel's findings regarding penalty provisions and audit procedures, the United States requests the Appellate Body to complete the Panel's analysis and to find that divergences in penalty provisions and audit procedures in the European Communities

\footnotetext{
${ }^{75}$ United States' appellant's submission, para. 132 (referring to Panel Report, Argentina - Hides and Leather, paras. 11.72, 11.94, and 11.101).

${ }^{76}$ Ibid., paras. 134-139.

${ }^{77}$ Ibid., para. 154.
} 
WT/DS315/AB/R

Page 14

amount to non-uniform administration of European Communities customs law in breach of Article X:3(a) ${ }^{78}$

(b) Completing the Analysis with respect to the "As a Whole" Challenge of the United States under Article X:3(a) of the GATT 1994

32. In the event the Appellate Body reverses the Panel's finding that its terms of reference regarding the United States' claim under Article X:3(a) of the GATT 1994 do not include a challenge to the European Communities' system of customs administration "as a whole", or an "as such" challenge with respect to the design and structure of this system, the United States requests the Appellate Body to complete the analysis and find that the design and structure of the European Communities' system of customs administration "as a whole" is inconsistent with Article X:3(a). ${ }^{79}$ The United States submits that, in this dispute, "a reversal of the Panel's findings without a completion of the analysis would fail 'to secure a positive solution to [the] dispute"'. ${ }^{80}$

33. The United States submits that the analysis can be completed on the basis of undisputed facts and the Panel's findings of fact regarding the European Communities' system of customs administration. ${ }^{81}$ The United States recalls that "[t]he crux of the [United States'] claim ... was that the existence of a system of customs administration in which 25 separate, independent authorities exercise judgment in interpreting and applying [European Communities] customs law, without any procedures or institutions to ensure against divergences or to reconcile them promptly and as a matter of right when they occur necessarily constitutes a lack of uniform administration, in breach of Article X:3(a)." ${ }^{82}$ The United States points to statements made by the Panel with respect to various mechanisms and institutions in the European Communities that, according to the European Communities, are supposed to ensure against divergences or to reconcile divergences when they occur. $^{83}$ The United States mentions as particular examples, the Customs Code Committee ${ }^{84}$, Article 10 of the Treaty Establishing the European Communities (the "EC Treaty"), and the system of preliminary reference of questions of European Communities customs law to the Court of Justice of the European Communities (the "ECJ"). ${ }^{85}$ The United States also refers to the Panel's statement that the European Communities' system of customs administration "as a whole" is "complicated and, at

\footnotetext{
${ }^{78}$ United States' appellant's submission, para. 159.

${ }^{79}$ Ibid., para. 99.

${ }^{80}$ Ibid., para. 101.

${ }^{81}$ Ibid., para. 102.

${ }^{82}$ Ibid. (footnote omitted)

${ }^{83}$ Ibid.

${ }^{84}$ Committee established by Articles 247a(1) and 248a(1) of the Community Customs Code.

${ }^{85}$ United States' appellant's submission, paras. 103, 104, and 105.
} 
times, opaque and confusing". ${ }^{86}$ According to the United States, by these various statements, the Panel rejected the European Communities' argument that the institutions and procedures to which the European Communities referred ensure the uniform administration of European Communities customs law. ${ }^{87}$ Thus, for the United States, in the light of the Panel's statements regarding "the institutions and mechanisms the [European Communities] held out as securing uniform administration of [European Communities] customs law, completion of the Panel's analysis should be straightforward" ${ }^{18}$ and should lead to the conclusion that "the [European Communities'] system of customs administration as a whole is inconsistent with the [European Communities'] obligation of uniform administration under Article X:3(a) of the GATT 1994." ${ }^{89}$

\section{The Panel's Interpretation of Article X:3(b) of the GATT 1994}

34. The United States submits that the Panel erred in finding that the tribunals and procedures for review of customs administrative actions in the European Communities are consistent with Article X:3(b) of the GATT 1994, despite the fact that their decisions do not govern the practice of all the agencies entrusted with administrative enforcement throughout the territory of the European Communities.

35. The United States notes that review tribunals or procedures of the European Communities consist of the courts of various member States. Each court issues decisions that govern the practice of only the agency in the respective member State. ${ }^{90}$ The United States claims that, in reaching its conclusion concerning interpretation and application of Article X:3(b), the Panel made a number of interpretive errors. In the United States' view, the Panel misconstrued the ordinary meaning of the terms "the agencies" and "such agencies"; confused the concepts of "implement" and "govern the practice of"; and failed to take into account the context provided by Article X:3(a) of the GATT 1994. ${ }^{91}$ The United States submits that the Panel effectively disregarded the ordinary meaning of those terms when it stated that "it is difficult to know what significance should be attached, if any, to the reference to agencies in the plural." ${ }^{92}$ The United States submits that the ordinary meaning of the plural form encompasses "the agencies"—-without limitation—as opposed to only one such agency

\footnotetext{
${ }^{86}$ United States' appellant's submission, para. 107 (quoting Panel Report, para. 7.191).

${ }^{87}$ Ibid., para. 108.

${ }^{88}$ Ibid.

${ }^{89}$ Ibid.

${ }^{90}$ Ibid., para. 31.

${ }^{91}$ Ibid., para. 163.

${ }^{92}$ Panel Report, para. 7.528 (quoted in United States' appellant's submission, para. 164).
} 
WT/DS315/AB/R

Page 16

or just "some of" or a subset of "the agencies". ${ }^{93}$ The United States argues that the use of the plural form contemplates multiple agencies and, given the absence of any basis in the text for distinguishing among multiple agencies, it must contemplate all the agencies entrusted with administrative enforcement. ${ }^{94}$

36. Furthermore, in the United States' view, Article X:3(b) must be read in the light of the obligation of uniform administration in Article X:3(a) of the GATT 1994. According to the United States, the review of decisions that are inconsistent with "established principles of law or the actual facts" contemplated by Article X:3(b) also embodies the principle of uniform administration. ${ }^{95}$ The United States submits that procedures leading to decisions that have effect only in particular regions of a WTO Member's territory are therefore inconsistent with Article X:3(b). In addition, the United States alleges that the Panel did not give meaning to the two distinct requirements of "govern the practice" and "implement" in Article X:3(b). ${ }^{96}$ In the United States' view, the Panel assumed incorrectly that, if a decision can be implemented by a single agency, then the decision need govern the practice of only that agency, even though, pursuant to Article X:3(b), it must be effectuated by "such agencies" entrusted with administrative enforcement. ${ }^{97}$ The United States submits that Article X:3(b) does not contemplate such a geographical limitation of the "govern the practice" requirement. $^{98}$

37. With respect to the Panel's assessment of what is "reasonable" in the light of "most legal systems", the United States submits that the Panel ignored the feature that distinguishes the system of the European Communities from most legal systems, namely, that most legal systems have only one central agency entrusted with enforcement of customs law. The United States points out that this is not the case in the European Communities because its legal system combines review tribunals with geographically limited jurisdiction with customs authorities whose practice is limited to particular geographical regions. ${ }^{99}$ In the United States' view, this results in a geographically fragmented administration of the customs law in the European Communities. ${ }^{100}$

\footnotetext{
${ }^{93}$ United States' appellant's submission, para. 165.

${ }^{94}$ Ibid., para. 166.

${ }^{95}$ Ibid., para. 181.

${ }^{96}$ Ibid., para. 174.

${ }^{97}$ Ibid.

${ }^{98}$ Ibid., para. 191.

${ }^{99}$ Ibid., para. 189.

${ }^{100}$ Ibid.
} 
38. In the United States' view, should the Appellate Body reverse the Panel's finding on Article X:3(b) of the GATT 1994, it should also complete the Panel's analysis and find the European Communities to be in breach of its obligation under Article X:3(b) "by failing to provide review tribunals or procedures whose decisions govern the practice of all of the agencies that the [European Communities] entrusts with administrative enforcement of its customs laws." ${ }^{101}$

\section{B. Arguments of the European Communities - Appellee}

\section{The Panel's Terms of Reference}

39. The European Communities submits that the Panel did not err in finding that the measure at issue was only the "manner of administration" of European Communities customs law in the specific areas identified by the United States in the panel request. Furthermore, the European Communities agrees with the Panel's conclusion that its terms of reference did not include a claim against the European Communities' system of customs administration "as a whole", or "as such".

(a) The "Measures at Issue" for Purposes of a Claim under Article X:3(a) of the GATT 1994

40. The European Communities agrees with the Panel that the measure at issue with respect to the United States' claim under Article X:3(a) of the GATT 1994 is the "manner of administration" of European Communities customs law. ${ }^{102}$ The European Communities considers that, by referring to the "manner of administration", the Panel did not blur the distinction between the measure at issue and the claims under Article X:3(a). The Panel used the term "manner of administration" to distinguish "administration" (the measure at issue in this dispute) from the laws and regulations of general application under Article X:1 of the GATT 1994, which are the subject of administration. According to the European Communities, the Panel used the term "manner of administration" synonymously with "administration". ${ }^{103}$ The European Communities is of the view that this "minor ambiguity"104 is not enough to reverse the Panel's finding that when a violation of Article X:3(a) is claimed, the panel request must identify a "manner of administration".

41. The European Communities contends that the United States is trying to confuse the laws to be administered with their administration. ${ }^{105}$ In this respect, the European Communities observes that, in

\footnotetext{
${ }^{101}$ United States' appellant's submission, para. 200.

${ }^{102}$ European Communities' appellee's submission, para. 97.

${ }^{103}$ Ibid., para. 91.

${ }^{104}$ Ibid., para. 92.

${ }^{105}$ Ibid., para. 94 (referring to Appellate Body Report, EC - Bananas III, para. 200).
} 
WT/DS315/AB/R

Page 18

EC - Bananas III, the Appellate Body distinguished, in the context of Article X:3(a), between the administration of the laws and the laws to be administered. ${ }^{106}$ According to the European Communities, the panel request refers to the manner of administration ${ }^{107}$, "clearly distinguishes the administration from the laws which are being administered", and, thus, "identifies the 'administration', rather than those laws, as the measure at issue in the dispute."108

(b) Confinement of the Measures at Issue to Certain Areas of Customs Administration

42. For the European Communities, the Panel was fully justified in concluding that the measure at issue was only the administration of customs law in the areas identified in the third paragraph of the panel request. The European Communities reiterates that, in this case, the measure at issue is not the set of legal instruments listed in the first paragraph of the panel request but, rather, their administration. ${ }^{109}$ The European Communities submits that the United States is trying to engage in a selective reading of the panel request by asking the Appellate Body to ignore the third paragraph of the panel request. ${ }^{110}$ Furthermore, given the "vast body of law"111 ${ }^{111}$ referred to by the United States in the first paragraph of the panel request, it would not have been possible for the European Communities to prepare adequately its defence purely on the basis of a challenge against the administration of European Communities customs law "as a whole" without specifying the relevant provisions or sectors. In the view of the European Communities, "an identification of the specific issue or provision with respect to which a claim of non-uniform administration is made was ... necessary ... to protect [its] due process rights". ${ }^{112}$

43. The European Communities contends that the Panel correctly referred to the general principle set out in EC - Computer Equipment that "what is necessary for identification of the 'specific measures at issue' depends on the circumstance of the case."113 In the circumstances of the present case, given the vast body of law to which the United States referred, the Panel was justified in requiring specification of areas of customs administration.

\footnotetext{
${ }^{106}$ European Communities' appellee's submission, para. 94.

${ }^{107}$ Ibid., para. 95.

${ }^{108}$ Ibid., para. 96.

${ }^{109}$ Ibid., para. 99.

${ }^{110}$ Ibid., para. 100.

${ }^{111}$ Ibid., para. 103.

${ }^{112}$ Ibid. (footnote omitted)

${ }^{113}$ Ibid., para. 105.
} 
44. Regarding the terms "including but not limited to" contained in the third paragraph of the panel request, the European Communities relies on the Appellate Body Report in India - Patents (US) in asserting that "these words cannot have the effect of including, contrary to the requirements of Article 6.2 [of the] DSU, the administration of the entire body of [European Communities] customs law into the Panel's terms of reference." ${ }^{114}$ The European Communities adds that the United States' interpretation of this phrase would reduce the third paragraph of the panel request to inutility ${ }^{115}$ and would "prejudice [the defendant's] due process rights by leaving the actual subject matter of the case unclear." 116

(c) Challenging the European Communities' System of Customs Administration "As a Whole"

45. According to the European Communities, the Appellate Body should uphold the Panel's findings that the United States' claims regarding the European Communities' system "as a whole" and "as such" are outside its terms of reference. The European Communities considers the "as a whole" claim to be outside the Panel's terms of reference because the measure at issue is "only the [European Communities'] manner of administration in the areas of customs law specifically identified in [the] Panel request". ${ }^{117}$ The European Communities also maintains that "[i]t is thus incorrect to suggest that the [European Communities'] system of customs administration could be assessed 'as a whole', independently of the specific needs and requirements of the sector or area in question, and the tools and mechanisms existing in such area." ${ }^{118}$

46. The European Communities argues that the panel request did not indicate that the United States intended to challenge the European Communities' system of customs administration "as such". For the European Communities, the panel request identified as the measure at issue the "manner of administration", and these terms are "diametrically opposed to those which one could have expected to be used in the case of a challenge against a measure 'as such'."119 Regarding the United States' argument that the measures at issue were the instruments listed in the first paragraph of the panel request, and that they constitute the main instruments of the European Communities customs legislation, the European Communities reiterates its view that the measures at issue are not these instruments but, rather, their administration in the areas listed in the third paragraph of the panel

\footnotetext{
${ }^{114}$ European Communities' appellee's submission, para. 106.

${ }^{115}$ Ibid., para. 108.

${ }^{116}$ Ibid., para. 109.

${ }^{117}$ Ibid., para. 113.

${ }^{118}$ Ibid., para. 117.

${ }^{119}$ Ibid., para. 125.
} 
WT/DS315/AB/R

Page 20

request. The European Communities adds that its system of customs administration is broader than the instruments listed in the first paragraph of the panel request, because it includes other instruments such as the EC Treaty itself and more specific instruments existing in the field of customs cooperation, or budgetary and financial control. ${ }^{120}$

47. With respect to the United States' reliance on a number of statements made by the parties during or outside the Panel proceedings ${ }^{121}$, the European Communities recalls that "the compliance of a [p]anel request with Article 6.2 [of the] DSU must be assessed primarily on the face of the [p]anel request". ${ }^{122}$ The European Communities reiterates that at no point did it recognize or acknowledge that its system of customs administration "as such" was the measure at issue in this dispute. ${ }^{123}$

\section{Claims regarding Article X:3(a) of the GATT 1994}

(a) The Panel's Interpretation of the Term "Administer" in Article X:3(a) of the GATT 1994

48. The European Communities submits that the Panel was correct to distinguish between the laws to be administered and the administration of those laws, and disagrees with the United States that laws themselves can constitute administration. According to the European Communities, the administration of a law or a regulation of general application, by definition, implies its application in concrete cases. ${ }^{124}$

49. The European Communities argues that the Panel did not err in finding that substantive differences in the penalty laws of the member States of the European Communities, in and of themselves, do not constitute a violation of Article X:3(a) of the GATT 1994.

50. According to the European Communities, the United States did not demonstrate that differences in the penalty laws of the member States lead to non-conformity in the administration of European Communities customs law. The European Communities explains that, although administrative or penalty provisions applicable to violations of customs law are set out in the individual laws of the member States, the member States do not have complete freedom in the determination of the appropriate level of penalties. Rather, in accordance with the binding principles of European Communities customs law, sanctions for the violation of customs law that member States

\footnotetext{
${ }^{120}$ European Communities' appellee's submission, para. 128.

${ }^{121}$ United States' appellant's submission, paras. 84-98.

${ }^{122}$ European Communities' appellee's submission, para. 131. See also paras. $87 \mathrm{ff}$.

${ }^{123}$ Ibid., para. 133.

${ }^{124}$ Ibid., paras. 207-215.
} 
provide must be effective, proportionate, and dissuasive. ${ }^{125}$ In the European Communities' view, these principles ensure uniform application of customs law throughout the European Communities. ${ }^{126}$

51. The European Communities emphasizes that the objective of ensuring uniform application of European Communities customs law does not require full harmonization of penalty provisions among the member States, and that differences in penalties do not necessarily lead to a lack of uniformity in the application of the provisions. ${ }^{127}$ The European Communities submits that, if sanctions are dissuasive and effective, then it must be assumed that the related substantive provisions will be respected, regardless of differences in the level of sanctions applicable. The European Communities contends that the United States has not provided any evidence concerning the actual nature and level of sanctions imposed by the laws of member States for specific violations of customs provisions. Therefore, in the European Communities' view, the United States has not established that differences in penalty laws result in differences in the administration of European Communities customs law. ${ }^{128}$

52. With respect to the administration of audit procedures, the European Communities submits that the Panel was correct to find no violation of Article X:3(a). ${ }^{129}$ The European Communities disagrees with the United States that the same arguments it submitted when challenging the Panel's findings with respect to penalty laws apply with equal force to the Panel's findings with respect to audit procedures. In the European Communities' view, these claims are substantially different, because audit procedures are not primarily set out in member States' laws. ${ }^{130}$ The European Communities asserts that uniform practice in this respect is ensured by the Community Customs Audit Guide. ${ }^{131}$

53. The European Communities notes the discretionary character of Article 78(2) of the Community Customs Code but argues that, nevertheless, the mere exercise of discretion in one way or another does not constitute non-uniform administration. ${ }^{132}$ The European Communities submits that "the [United States] has not provided any evidence to substantiate its allegation that there are significant differences in the audit procedures followed by the ... [m]ember States" ${ }^{133}$, and "has also

\footnotetext{
${ }^{125}$ European Communities' appellee's submission, paras. 202 and 222.

${ }^{126}$ Ibid., para. 222.

${ }^{127}$ Ibid., para. 223.

${ }^{128}$ Ibid., paras. 221-232.

${ }^{129}$ Ibid., paras. 46 and 233.

${ }^{130}$ Ibid., para. 234.

${ }^{131}$ Ibid., para. 237 (referring to Community Customs Audit Guide, a framework for post-clearance and audit-based controls (Exhibit EC-90 submitted by the European Communities to the Panel)).

${ }^{132}$ Ibid., para. 241.

${ }^{133}$ Ibid., para. 249.
} 
WT/DS315/AB/R

Page 22

not been able to demonstrate what impact, if any, such differences would have on the uniform administration of [European Communities] customs law."134

54. Regarding the United States' request that the Appellate Body complete the analysis under Article X:3(a) with respect to penalty provisions and audit procedures, the European Communities maintains that the Panel did not make the necessary findings of fact and that there are no undisputed facts on the record that would enable the Appellate Body to complete the analysis. ${ }^{135}$

(b) Completing the Analysis with respect to the "As a Whole" Challenge of the United States under Article X:3(a) of the GATT 1994

55. In the event that the Appellate Body reverses the Panel's findings regarding its terms of reference, the European Communities submits that the Appellate Body is not in a position to complete the legal analysis and should decline to find that the European Communities' system of customs administration "as a whole" and "as such" is inconsistent with Article X:3(a) of the GATT $1994 .{ }^{136}$

56. The European Communities disagrees with the United States that there are enough factual findings made by the Panel, or enough undisputed facts on record, that would enable the Appellate Body to find that the European Communities' system of customs administration "as such" and "as a whole" is inconsistent with Article X:3(a). According to the European Communities, the Panel's statements to which the United States refers are isolated remarks in the Panel Report where the Panel commented on individual aspects of the European Communities' system of customs administration. ${ }^{137}$ These statements, the European Communities argues, would not allow the Appellate Body to assess whether the European Communities' system of customs administration "as a whole" and "as such" is in conformity with Article X:3(a) of the GATT 1994, given that they do not contain findings of fact in this regard, and were not intended by the Panel to constitute such findings. ${ }^{138}$ The European Communities notes that these statements are contained in a section where the Panel set out its understanding of the European Communities' system of customs administration as "context" for the evaluation of the United States' claims regarding individual instances of application. ${ }^{139}$

57. Furthermore, the European Communities emphasizes that the Panel observed, inter alia, that "the United States did not demonstrate that the design and structure of the [European Communities']

\footnotetext{
${ }^{134}$ European Communities' appellee's submission, para. 250.

${ }^{135}$ Ibid., paras. 231 and 251.

${ }^{136}$ Ibid., paras. 141-142.

${ }^{137}$ Ibid., para. 159.

${ }^{138}$ Ibid., para. 160.

${ }^{139}$ Ibid.
} 
system of customs administration, including components thereof, necessarily result in a violation of Article X:3(a) of the GATT 1994". ${ }^{40}$ Thus, in the European Communities' view, the Panel explicitly confirmed that the United States did "not even come close" to establishing that the European Communities' system of customs administration "as such" and "as a whole" entails a violation of Article X:3(a) of the GATT $1994 .^{141}$

58. Finally, the European Communities submits that the United States' claim regarding the European Communities' system of customs administration "as a whole" is a claim that has not been explored by the Panel, and the Panel has therefore not made any legal findings and interpretations on this claim that the Appellate Body could reverse. For the European Communities, a claim of violation of the obligation of uniform administration directed against individual instances of application is fundamentally different from a claim directed against a system of customs administration "as such" and "as a whole". ${ }^{142}$ Adjudging the claim regarding the European Communities' system of customs administration "as such" and "as a whole" would, therefore, violate the due process rights of the participants, and of the European Communities in particular. Appellate Body proceedings have to take place within a narrow time-frame, and are focused on issues of law and legal interpretations. For the European Communities, such proceedings are manifestly not suited for investigating a claim against a system of customs administration "as a whole" and "as such". ${ }^{143}$

\section{The Panel's Interpretation of Article X:3(b) of the GATT 1994}

59. The European Communities argues that the Panel was correct in finding that the European Communities has not violated Article X:3(b) of the GATT 1994, because this provision does not require that the review of administrative action relating to customs matters must have effect throughout the territory of the European Communities. ${ }^{144}$

60. As a general matter, the European Communities notes that all disputes concerning European Communities law that are not subject to the jurisdiction of the ECJ and the Court of First Instance of the European Communities (the "CFI") fall within the competence of the national courts of the member States. The European Communities explains that national courts have a dual function: when deciding a dispute governed by national law, they form part of the national legal order; when

\footnotetext{
${ }^{140}$ European Communities' appellee's submission, para. 29 (quoting Panel Report, para. 7.490).

${ }^{141}$ Ibid., paras. 171-172.

${ }^{142}$ Ibid., paras. $188-189$.

${ }^{143}$ Ibid., paras. 193-195.

${ }^{144}$ Ibid., paras. 257 and 342.
} 
WT/DS315/AB/R

Page 24

deciding a case governed by European Communities law, they belong, from the functional point of view, to the European Communities' legal order. ${ }^{145}$

61. The European Communities points out that, in the case of actions brought before a national court that relate to the interpretation of an issue of European Communities law, the national court may request the ECJ to interpret a question of European Communities law (referred to as "references for a preliminary ruling"). ${ }^{146}$ Member State courts, against whose decisions there is no judicial remedy under national law, are required to refer issues of interpretation of European Communities law to the ECJ. ${ }^{147}$ Since European Communities customs law is implemented through the customs authorities of the member States, an appeal for judicial review is lodged before the court of the member State whose customs authorities have issued the decision. ${ }^{148}$ According to the European Communities, the main objective of the preliminary reference procedure is to guarantee the proper and uniform interpretation and application of European Communities law throughout all the member States, while avoiding the establishment of a long and expensive appellate system before the ECJ. ${ }^{149}$ The European Communities notes that a preliminary ruling by the ECJ is binding on the national court hearing the case in which the ruling is given, and that it has effect also on persons who are not parties to the case referred. ${ }^{150}$ The European Communities points out that, in exceptional cases, a right of appeal against member State customs decisions may also be available directly to the CFI. ${ }^{151}$

62. The European Communities submits that the Panel gave the correct meaning to the terms "the agencies entrusted with administration enforcement" and "such agencies" in Article X:3(b) of the GATT 1994. In the European Communities' view, the Panel correctly explained that the use of the plural when referring to "agencies" in Article X:3(b) could flow from the fact that the review "tribunals and procedures" required under the same provision are also referred to in the plural. ${ }^{152}$ The European Communities disagrees with the United States' argument that the use of the singular in the proviso indicates that only one entity within a WTO Member should be permitted "to pursue" the

\footnotetext{
${ }^{145}$ European Communities' appellee's submission, paras. 260-261.

${ }^{146}$ Ibid., para. 266.

${ }^{147}$ Ibid., para. 267.

${ }^{148}$ Ibid., para. 274.

${ }^{149}$ Ibid., para. 270.

${ }^{150}$ Ibid., para. 272.

${ }^{151}$ Ibid., para. 279. This is the case when the European Commission takes decisions that are of direct

${ }^{152}$ Ibid., para. 288 (referring to Panel Report, para. 7.527).
} and individual concern to individuals. 
review. In the European Communities' view, the proviso covers the "central administration of any of those agencies existing in the WTO [M]ember". ${ }^{153}$

63. In response to the United States' argument that the Panel failed to give meaning to the distinct requirements in Article X:3(b) that review decisions must be "implemented by" and "govern the practice of" such agencies ${ }^{154}$, the European Communities submits that the differences between the terms "to implement" and "govern the practice of" are irrelevant for interpreting the term "the agencies". Furthermore, the European Communities notes that the absence of an express reference to Article X:3(a) in Article X:3(b) of the GATT 1994 contrasts with the explicit reference by Article X:3(c) to Article X:3(b) of the GATT 1994. The European Communities agrees with the Panel that this absence precludes an inference that the obligation to ensure review of administrative action under Article X:3(b) could be read as simultaneously requiring uniform administration in accordance with Article X:3(a) of the GATT 1994, because "such an interpretation would amount to merging different requirements that are currently contained in separate subparagraphs of Article $\mathrm{X}$ of the GATT 1994."155 The European Communities argues that this interpretation is also supported by the negotiating history of Article $\mathrm{X}^{156}$ The European Communities concurs with the Panel that it would not be reasonable to infer that "first instance independent review tribunals and bodies, whose jurisdiction in most legal systems is normally limited in substantive and geographical terms, should have the authority to bind all agencies entrusted with administrative enforcement throughout the territory of a Member". ${ }^{157}$

64. Finally, the European Communities submits that the United States' interpretation would lead to a major conflict between the Marrakesh Agreement Establishing the World Trade Organization (the "WTO Agreement") and the EC Treaty, because the creation of a central European Communities customs court of first instance would require a profound constitutional amendment of the EC Treaty that would require ratification by its 25 member States. The European Communities recalls that, when the WTO Agreement was negotiated and concluded, the United States never raised any concern about the European Communities' system of judicial review, which had already existed for almost 40 years. ${ }^{158}$

\footnotetext{
${ }^{153}$ European Communities' appellee's submission, para. 291.

${ }^{154}$ Ibid., para. 293 (referring to United States' appellant's submission, para. 174).

${ }^{155}$ Ibid., para. 302 (quoting Panel Report, para. 7.534).

${ }^{156}$ See ibid., paras. 313-322.

${ }^{157}$ Ibid., para. 325 (referring to United States' appellant's submission, para. 188).

${ }^{158}$ Ibid., para. 339.
} 
WT/DS315/AB/R

Page 26

C. Claims of Error by the European Communities - Other Appellant

\section{The Panel's Terms of Reference}

(a) Temporal Limitations of the Panel's Terms of Reference

65. The European Communities contends that the Panel took an excessively wide approach to the temporal reach of its terms of reference. ${ }^{159}$ For the European Communities, a panel may, in principle, consider only measures that are in existence at the time of its establishment ${ }^{160}$ and, therefore, the Panel erred in considering that it had "a general competence to also consider measures which 'predate' or 'post-date' its establishment."161 The European Communities refers to past Appellate Body and panel reports in support of its arguments. ${ }^{162}$ The European Communities argues that, furthermore, the manner of administration "cannot be regarded as a 'continuum' without [a] clear start or end point", contrary to what the Panel suggests. ${ }^{163}$ According to the European Communities, the Panel's approach would produce absurd results: it would imply that "violations which occurred far in the past and which no longer have any current effect could be claimed to be continuing because 'administration has no end point"'164; similarly, "violations which had not yet occurred at the time the Panel was established might be regarded as indicative of violations pre-dating the Panel's establishment because administration 'has no starting point'."165

66. The European Communities considers that, on the basis of the panel request, it was entitled to assume that the complainant's case related to measures in existence at the time of the Panel's establishment. The European Communities contends that, by defining "administration" under Article X:3(a) of the GATT 1994 as a "phenomenon without any boundaries in time", the Panel violated the due process rights of the defendant protected by Article 6.2 of the DSU, because the preparation of the defence for past instances of administration is "unduly difficult", and including

\footnotetext{
${ }^{159}$ European Communities' other appellant's submission, para. 40.

${ }^{160}$ Ibid., para. 46 (referring to Appellate Body Report, EC - Chicken Cuts, para. 156).

${ }^{161}$ Ibid., para. 47.

${ }^{162}$ The European Communities refers to Appellate Body Reports in Chile - Price Band System, para. 139; EC - Chicken Cuts, para. 56; EC - Computer Equipment, para. 81; and US - Upland Cotton, paras. 262-263 and 272; and to Panel Reports in EC - Computer Equipment, para. 8.14; Japan - Film, para. 10.58; and US - Upland Cotton, paras. 7.158-7.160. (Ibid., paras. 46-59)

${ }^{163}$ Ibid., para. 63; Panel Report, para. 7.37.

${ }^{164}$ European Communities' other appellant's submission, para. 65.

${ }^{165}$ Ibid.
} 
future instances of administration in the measure at issue would make the subject matter of the case a "moving target". 166

67. The European Communities also argues that the Panel's reasoning would render establishing compliance almost impossible. If administration has no clear start or end point, it would be difficult for a WTO Member found to be in violation of Article X:3(a) to establish that it has altered its manner of administration so that compliance with Article X:3(a) is achieved. ${ }^{167}$ The European Communities contends that "the Panel's approach to the temporal limitations to its terms of reference is incompatible with Article[s] 7.1 and 6.2 [of the] DSU"168 and requests the Appellate Body to reverse the Panel's findings on the temporal limitations of its terms of reference. ${ }^{169}$

\section{Claims regarding Article X:3(a) of the GATT 1994}

(a) The Administrative Process and the Requirement of Uniformity

68. The European Communities submits that the Panel erred in finding that "Article X:3(a) of the GATT [1994] requires uniformity of administrative processes irrespective of their impact on the uniform administration of the laws." ${ }^{170}$

69. The European Communities agrees with the Panel that the term "to administer" relates to the application of laws, and that this may potentially include both the administrative processes as well as their results. However, for the European Communities, Article X:3(a) does not require that the administrative process "be fully uniform in all cases and respects". ${ }^{171}$ The European Communities emphasizes that "[i]n most administrations, procedures are not fully regulated or harmonised." ${ }^{172}$ The European Communities doubts that a total uniformity of administrative procedures is required in order to ensure that traders are treated fairly and consistently. In the view of the European Communities, whether the requirement of uniform administration in Article X:3(a) is met should be evaluated primarily on the basis of the administrative outcome. The European Communities argues that "[a]part from the case that the administrative process is regulated in laws or regulations of general application themselves, the obligation of uniform administration only extends to the administrative process to the

\footnotetext{
${ }^{166}$ European Communities' other appellant's submission, para. 66.

${ }^{167}$ Ibid., para. 68.

${ }^{168}$ Ibid., para. 69.

${ }^{169}$ Ibid., para. 70; Panel Report, paras. 7.36-7.37.

${ }^{170}$ European Communities' other appellant's submission, para. 82; Panel Report, paras. 7.102-7.113

${ }^{171}$ European Communities' other appellant's submission, para. 76.

${ }^{172}$ Ibid., para. 78.
} and 7.119. 
WT/DS315/AB/R

Page 28

extent that the administrative process has a direct and significant impact on the outcome of the process". ${ }^{173}$ Accordingly, the European Communities requests the Appellate Body to reverse the Panel's finding that Article X:3(a) of the GATT 1994 requires uniformity of administrative processes irrespective of their impact on the uniform administration of the laws. ${ }^{174}$

(b) The Administrative Process Leading to the Tariff Classification of Blackout Drapery Lining

70. The European Communities submits that the Panel erred in finding that the European Communities has violated Article X:3(a) of the GATT 1994 with respect to the tariff classification of blackout drapery lining. ${ }^{175}$ In particular, the European Communities challenges the Panel's findings relating to the administrative process governing the tariff classification of blackout drapery lining. The European Communities notes that the Panel reached these findings "even though it also found that there was no evidence of an actual divergence in the tariff classification of [blackout drapery lining]". ${ }^{176}$ For the European Communities, the Panel erred because it overstepped its terms of reference by making findings with respect to expired measures, failed to make an objective assessment of the facts as required by Article 11 of the DSU, and misapplied the requirements of Article X:3(a) of the GATT 1994.

71. The European Communities contends that the findings of the Panel concerning blackout drapery lining are outside its terms of reference because they are exclusively based on the reasoning of the decisions and letters of the German customs authorities in two isolated past cases. The European Communities points out that the letter of the Main Customs Office Hamburg to Ornata GmbH dates from July 1998, the opinion of the ZPLA Hamburg in the Bautex-Stoffe GmbH case dates from February 2003, and the decision of the Main Customs Office Hamburg in the same case dates from September 2004. ${ }^{177}$ For the European Communities, these decisions and letters are expired measures because they concern past transactions and they no longer have any effects for the future. The European Communities submits that the Panel's findings regarding the "administrative process" relating to the tariff classification of blackout drapery lining are outside its terms of reference and should be reversed. ${ }^{178}$

\footnotetext{
${ }^{173}$ European Communities' other appellant's submission, para. 81.

${ }^{174}$ Ibid., para. 82.

${ }^{175}$ Ibid., para. 148.

${ }^{176}$ Ibid., para. 95 (referring to Panel Report, para. 7.265).

${ }^{177}$ Ibid., para. 106.

${ }^{178}$ Ibid., para. 110.
} 
72. With respect to the Panel's findings that the German customs authorities relied on an interpretative aid that is particular to Germany, the European Communities argues that the description of the facts made by the Panel does not correspond to an objective assessment of the facts, as required by Article 11 of the DSU. ${ }^{179}$ The European Communities argues that the decisions and letters to which the Panel referred did not rely on a German explanatory aid or on certain classification criteria in a way that would have been incompatible with the uniform application of European Communities customs law. ${ }^{180}$ The European Communities also recalls that the interpretive aid referred to by the Panel "is purely a non-binding text which does not in any way derogate from the application of [European] Communit[ies] law". ${ }^{181}$

73. With respect to the alleged failure of the German customs authorities to take into account the decisions of customs authorities of other member States, the European Communities argues that the decisions and letters to which the Panel referred do not indicate that the German customs authorities wished to ignore the decisions of other customs authorities. ${ }^{182}$ The European Communities adds that the factual basis for the Panel's findings is "extremely tenuous"183, because the Panel based its findings on one single case and ignored a letter that clearly illustrates that the German customs authorities do take into account the practice of other customs authorities concerning the classification of similar goods when they are made aware of them. ${ }^{184}$ The European Communities contends that the Panel's statement that "German customs authorities are not obliged to make reference to the decisions of other customs authorities when classifying blackout drapery lining, even in cases where there is a possibility that the products ... subject [to] those decisions are the same or similar" ${ }^{185}$, contradicts Articles 6(3) and 2(1) of the Community Customs Code.

74. For the European Communities, even if the facts set out in the Panel Report were correct, they would not amount to an "act of non-uniform administration" within the meaning of Article X:3(a). ${ }^{186}$ The European Communities considers that the Panel's findings are based on the "motivation" of decisions and letters issued by the German authorities, which can hardly be regarded as part of the "administration process". ${ }^{187}$ Even if it were to be regarded as such, not every variation in the

\footnotetext{
${ }^{179}$ European Communities' other appellant's submission, para. 111.

${ }^{180}$ Ibid., paras. $114-115$.

${ }^{181}$ Ibid., para. 132 (referring to Panel Report, para. 7.239).

${ }^{182}$ Ibid., paras. $118-119$ and 141.

${ }^{183}$ Ibid., para. 144.

${ }^{184}$ Ibid., paras. $120-121$.

${ }^{185}$ Panel Report, para. 7.276 (quoted in European Communities' other appellant's submission,

${ }^{186}$ European Communities' other appellant's submission, para. 124.

${ }^{187}$ Ibid., paras. $126-127$ and 138.
} para. 122). 
WT/DS315/AB/R

Page 30

reasoning of the decisions of customs authorities could be regarded as amounting to non-uniform administration, because a violation of that obligation can only be assumed to exist where the divergence has a direct impact on administrative outcomes. ${ }^{188}$ In the European Communities' view, Article X:3(a) does not require the reasoning of decisions of customs authorities to be uniform; this would be contrary to the very purpose of the "motivation", which is to set out the reasons that led to the decision in the circumstances of the particular case. ${ }^{189}$ The European Communities points out that the Panel recognized that "there was no evidence that there had been a lack of uniformity as regards the actual tariff classification."190

\section{(c) Tariff Classification of Liquid Crystal Display Monitors with Digital Video Interface}

75. The European Communities submits that the Panel erred in finding that the European Communities has violated Article X:3(a) of the GATT 1994 with respect to the tariff classification of LCD monitors with DVI. ${ }^{191}$ According to the European Communities, "[t]he Panel overstepped its terms of reference by basing its findings of violation primarily on instances of administration which post-date its establishment". ${ }^{192}$ Specifically, the European Communities refers to the Dutch decree of 8 July 2005 and the German BTI of 19 July 2005. ${ }^{193}$ The European Communities also argues that the Panel did not make an objective assessment of the facts, as required by Article 11 of the DSU, because "the Panel did not have any evidence before it to support a finding that at the time of its establishment, there was a lack of uniform administration with regard to the tariff classification of LCD monitors." ${ }^{194}$

76. The European Communities submits that, "even if ... the Panel was justified in considering instances of administration which post-dated the time of its establishment", it nevertheless erred in finding a violation of Article X:3(a). ${ }^{195}$ The European Communities notes that uniformity under Article X:3(a) must be established "within a reasonable period of time"196, and maintains that this has

${ }^{188}$ European Communities' other appellant's submission, paras. 128 and 138.

${ }^{189}$ Ibid., para. 19.

${ }^{190}$ Ibid., para. 128.

${ }^{191}$ Ibid., para. 202.

${ }^{192}$ Ibid., para. 150.

${ }^{193}$ Ibid., para. 166 (referring to Douanerechten. Indeling van bepaalde LCD monitoren in de gecombineerde nomenclatuur [Customs Law: Classification of certain LCD monitors in the Combined Nomenclature], No. CPP2005/1372 M, 8 July 2005; and BTI DEM/2975/05-1, 19 July 2005 (Exhibits US-77 and US-78, respectively, submitted by the United States to the Panel).

${ }^{194}$ Ibid., para. 182.

${ }^{195}$ Ibid., para. 183.

${ }^{196}$ Ibid., para. 185. 
been achieved with the adoption of Commission Regulation (EC) No. 2171/2005 ("EC Regulation 2171/2005") on 23 December 2005, as well as with the withdrawal, in January 2006, of the Dutch decree and the German BTI. ${ }^{197}$ In this respect, the European Communities submits that the Panel erred in failing to take into account draft EC Regulation 2171/2005, because it had not yet been formally adopted. ${ }^{198}$ Also, the European Communities argues, the Panel erred in rejecting the evidence contained in exhibits provided by the European Communities at the interim review stage. ${ }^{199}$ According to the European Communities, the Panel's decision was not in accordance with Article 15.2 of the DSU, because this evidence related to precise aspects of the Panel's Interim Report. ${ }^{200}$ The European Communities considers that the strict approach taken by the Panel with respect to the evidence submitted by the European Communities during the interim review stage is "incompatible with its duty to make an objective assessment of the facts ... [g]iven the Panel's own liberal attitude towards its terms of reference, as well as the late admission of evidence provided by the United States". ${ }^{201}$ The European Communities, therefore, requests the Appellate Body to find that the Panel erred in rejecting exhibits submitted by the European Communities at the interim review stage. ${ }^{202}$

$$
\text { Administration of the Successive Sales Provision }
$$

77. The European Communities appeals the Panel's finding that the administration of Article 147(1) of the Implementing Regulation (the "successive sales provision") amounts to a violation of Article X:3(a) of the GATT 1994 because some member States of the European Communities impose a "form of prior approval" requirement while others do not. ${ }^{203}$

78. The European Communities submits that, in reaching this finding, the Panel failed to make an objective assessment of the facts and misapplied Article X:3(a). ${ }^{204}$ The European Communities claims that the Panel erred, in particular, in concluding that the United States had established a

${ }^{197}$ European Communities' other appellant's submission, para. 186 (referring to Commission Regulation (EC) No. 2171/2005 of 23 December 2005 concerning the classification of certain goods in the Combined Nomenclature; Dutch Ministry of Finance, Telefaxbericht, No. BCPP 2006/389 M, dated February 2006, on the withdrawal of decree No. CPP2005/1372 M; extract from the EBTI data base on the expired BTI DEM/2975/05-1 (Exhibits EC-167, EC-168, and EC-169, respectively, submitted by the European Communities to the Panel)). See also Panel Report, para. 6.3.

${ }^{198}$ European Communities' other appellant's submission, para. 190.

${ }^{199}$ The European Communities refers to Exhibits EC-167, EC-168, and EC-169, supra, footnote 197. See also Panel Report, paras. 6.3 and 6.6.

${ }^{200}$ European Communities' other appellant's submission, paras. 196-197.

${ }^{201}$ Ibid., para. 199.

${ }^{202}$ Ibid., para. 201 (referring to Panel Report, para. 6.6 and Exhibits EC-167, EC-168, and EC-169 submitted by the European Communities to the Panel).

${ }^{203}$ Ibid., paras. 203-229.

${ }^{204}$ Ibid., para. 204. 
WT/DS315/AB/R

Page 32

prima facie case that certain member States were imposing a requirement of prior approval. ${ }^{205}$ In the European Communities' view, the Panel erred in shifting the burden of proof from the United States to the European Communities. ${ }^{206}$

79. The European Communities submits that the United States supported its claim exclusively with a statement in the European Communities Court of Auditors Special Report No. 23/2000 concerning the valuation of imported goods for customs purposes ${ }^{207}$ (the "Court of Auditors Report"). The European Communities contends that the Court of Auditors' observation was not shared by other institutions of the European Communities and that, in particular, the European Commission confirmed that member States do not impose any requirement of prior approval. ${ }^{208}$

80. The European Communities contends that the Court of Auditors Report was not sufficient to establish a prima facie case of non-uniform administration of Article 147(1) of the Implementing Regulation, which does not contain a requirement of prior approval. The European Communities submits that: first, the statements relied upon by the Panel are excessively vague, because the Court of Auditors Report does not specify the precise nature of the "form of prior approval"; secondly, the Court of Auditors Report reflects the opinion of only one institution of the European Communities and does not take into account the opinions of other institutions, such as the European Commission; and thirdly, in the European Communities' view, the United States should have demonstrated nonuniform administration with evidence of actual administration rather than with the Court of Auditors Report. ${ }^{209}$ Finally, the European Communities argues that the Court of Auditors detected only "minor variations" in administrative practices, which do not "automatically translate" into a violation of Article X:3(a). ${ }^{210}$ In the European Communities' view, such variations will violate the obligation of uniform administration only if they are shown to have an impact on administrative outcomes. ${ }^{211}$

81. The European Communities submits that, even if the Panel was correct to assume that the burden of proof had shifted to the European Communities, it failed to give due weight to the

${ }^{205}$ European Communities' other appellant's submission, para. 204.

${ }^{206}$ See ibid., paras. 214-222.

${ }^{207}$ Court of Auditors, Special Report No. 23/2000 concerning valuation of imported goods for customs purposes (customs valuation), together with the Commission's replies, reproduced in Official Journal of the European Communities, C Series, No. 84, pp. 1-18 (14 March 2001) (Exhibit US-14 submitted by the United States to the Panel).

${ }^{208}$ European Communities' other appellant's submission, para. 207 (referring to Court of Auditors Report, supra, footnote 207, p. 17).

${ }^{209}$ Ibid., paras. 217-221.

${ }^{210}$ Ibid., para. 221.

${ }^{211}$ Ibid. 
information provided by the European Communities regarding the practice of its member States. ${ }^{212}$ As a result, the Panel erred in rejecting as evidence the communication between the European Communities and its member States, which the European Communities provided in its comments on the Panel's Interim Report. ${ }^{213}$

\section{Conditional Appeal of the European Communities}

82. The European Communities conditionally appeals the Panel's finding that Article XXIV:12 of the GATT 1994 cannot be relied upon to attenuate or to derogate from the provisions of Article X:3 of the GATT 1994. The European Communities requests a review of this finding only in the event that the Appellate Body's conclusions imply that the European Communities should "create a centralised customs agency replacing its [m]ember States in the implementation of [European Communities] customs law", or that the European Communities should "create [a European Communities]-level tribunal for the first-instance review of customs decisions". ${ }^{214}$

83. The European Communities does not contest that it is obliged to ensure uniform administration of its customs law, even where this law is being administered by its member States. ${ }^{215}$ However, the European Communities disagrees with the Panel's interpretation that Article XXIV:12 of the GATT 1994 "does not constitute an exception nor a derogation from the obligation of uniform administration in Article X:3(a) of the GATT 1994". 216 The European Communities submits that the question is not whether Article XXIV:12 is a "positive obligation" but, rather, what the content of this obligation is. ${ }^{217}$ The European Communities refers to the general principle of international law that States are responsible for the acts of all their organs and emanations, including their sub-federal and regional governments. ${ }^{218}$ According to the European Communities, this general principle did not require a specific confirmation in the GATT.

${ }^{212}$ European Communities' other appellant's submission, para. 223.

${ }^{213}$ Ibid., para. 227 (referring to Panel Report, paras. 6.6 and 7.427; and Exhibit EC-170 submitted by the European Communities to the Panel).

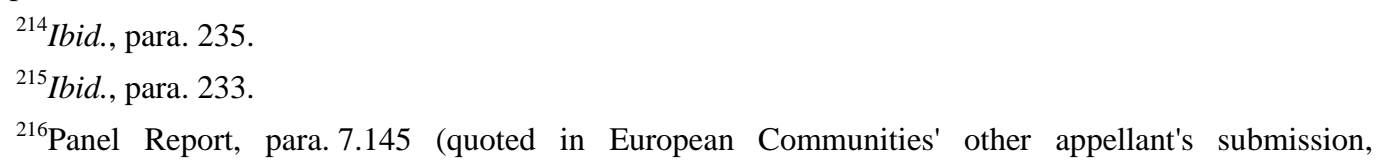
para. 241).

${ }^{217}$ European Communities' other appellant's submission, para. 242.

${ }^{218}$ The European Communities refers, in paragraph 243 of its other appellant's submission, to Article 4 of the Articles on the Responsibility of States for Internationally Wrongful Acts 2001. (Text adopted by the International Law Commission at its fifty-third session, in August 2001, and submitted to the General Assembly as a part of the Commission's report covering the work of that session.) The report, which also contains commentaries on the draft articles, appears in the Official Records of the General Assembly, Fifty-sixth Session, Supplement No. 10 (A/56/10). The text is reproduced in the annex to General Assembly Resolution 56/83 of 12 December 2001. 
WT/DS315/AB/R

Page 34

84. The European Communities emphasizes the specific reference in Article XXIV:12 to "reasonable measures as may be available" and submits that this language not only confirms the responsibility of WTO Members for their local and regional governments, it also sets out a standard for the type of measures that must be taken by WTO Members with respect to their local and regional governments. ${ }^{219}$ In the European Communities' view, the GATT panel in Canada - Gold Coins recognized this fact when it stated that "the consequences of ... non-observance [of GATT obligations] by the local government for trade relations with other [Members] are to be weighed against the domestic difficulties of securing observance". ${ }^{220}$ Therefore, the European Communities submits that Article XXIV:12 of the GATT 1994 serves as a "useful and necessary safeguard" in cases where a WTO Member is faced with claims that could be addressed only through major changes in the federal system within that WTO Member, as would be the case for a requirement to create a European Communities customs agency or customs court. ${ }^{221}$

D. Arguments of the United States - Appellee

1. The Panel's Terms of Reference

(a) Temporal Limitations of the Panel's Terms of Reference

85. The United States is of the view that the Panel did not err in its approach to the temporal scope of its terms of reference. ${ }^{222}$ The United States observes that the legal instruments it identified as the measures at issue in the panel request were in existence on the date when the Panel was established. ${ }^{223}$ For the United States, the European Communities' argument "confuses administration of [European Communities] customs law in existence when the Panel was established with individual acts of administration that occurred prior to establishment and with evidence that came to light during the panel proceeding that confirm the existence of non-uniform administration at the time of panel establishment." ${ }^{224}$ For the United States, the Panel correctly explained that "it would take account of individual instances of administration pre-dating and post-dating panel establishment not to determine whether each established a WTO-inconsistency in its own right, but as a means of elucidating the manner of administration that may be in existence at the time of panel establishment." ${ }^{225}$ The United

\footnotetext{
${ }^{219}$ European Communities' other appellant's submission, para. 243.

${ }^{220}$ GATT Panel Report, Canada - Gold Coins, para. 69 (quoted in European Communities' other appellant's submission, para. 244).

${ }^{221}$ European Communities' other appellant's submission, para. 247.

${ }^{222}$ United States' appellee's submission, para. 51.

${ }^{223}$ Ibid., para. 17.

${ }^{224}$ Ibid., para. 15. (original emphasis; footnote omitted)

${ }^{225}$ Ibid., para. 18 (referring to Panel Report, paras. 7.36-7.37).
} 
States considers that the Panel referred to individual acts of administration that pre-dated its establishment "not as potential breaches of Article X:3(a) of the GATT 1994 in and of themselves, but as evidence of the manner of administration of the relevant provisions of [European Communities] customs law."226

86. The United States is also of the view that the European Communities misreads the logical distinction the Panel made between administration as an ongoing phenomenon and individual instances of administration. $^{227}$ For the United States, although the European Communities has referred to the general principle that a panel may consider only measures in existence at the time of panel establishment, it made "no distinction between acts of administration themselves being considered as potential breaches of Article X:3(a) and acts of administration being considered as evidence of an ongoing course of administration that potentially is a breach of Article X:3(a)." ${ }^{228}$ The United States points out that nothing in the text of Article X:3(a) or its context suggests that a breach of Article X:3(a) "is demonstrated only when individual acts of administration in existence on the date a panel is established diverge."229 According to the United States, the European Communities' view is that administration is not a continuum, and that only individual acts of administration in existence at the time of panel establishment can be challenged as breaching Article X:3(a). If this understanding were correct, the United States argues, the obligation of uniform administration under Article X:3(a) would be rendered "ineffective"230 and would not meet the minimum standards of predictability for traders set out in Article X:3(a). ${ }^{231}$

87. Regarding the European Communities' argument concerning events that post-dated the Panel's establishment, the United States maintains that, contrary to the European Communities' assertions, the Panel's references to evidence post-dating its establishment do not show the Panel overstepping its terms of reference. According to the United States, "[t]hey show the Panel properly [took] account of evidence relevant to understanding the manner of administration of [European Communities] customs law existing at the time of panel establishment."232

\footnotetext{
${ }^{226}$ United States' appellee's submission, para. 22. (original emphasis)

${ }^{227}$ Ibid., para. 23.

${ }^{228}$ Ibid., para. 27.

${ }^{229}$ Ibid., para. 31.

${ }^{230}$ Ibid., para. 35.

${ }^{231}$ Ibid., paras. 32 and 41.

${ }^{232}$ Ibid., para. 46.
} 
WT/DS315/AB/R

Page 36

\section{2. $\quad$ Claims regarding Article X:3(a) of the GATT 1994}

(a) The Administrative Process and the Requirement of Uniformity

88. The United States asks the Appellate Body to reject the European Communities' request for a reversal of the Panel's finding that Article X:3(a) of the GATT 1994 "requires uniformity of administrative processes irrespective of their impact on the uniform administration of the laws". ${ }^{233}$

89. The United States disagrees with the European Communities' view that "the obligation of uniform administration only extends to the administrative process to the extent that the administrative process has a direct and significant impact on the outcome of the process". ${ }^{234}$ The United States points out that the European Communities failed to explain what it means by "administrative outcome" and how to distinguish administrative outcomes from administrative processes. ${ }^{235}$ For the United States, the exclusion of administrative processes from the obligation of uniform administration has no basis in the text of Article X:3(a). ${ }^{236}$ The United States considers that the European Communities' approach is too restrictive and would imply that significant areas of customs administration could be conducted in a non-uniform manner without breaching Article X:3(a). ${ }^{237}$ For the United States, from the trader's view, there is no basis for assuming that the outcome of administrative processes consists only of the release of an imported good with a particular classification and valuation into the customs territory of the European Communities, and does not also include the burden associated with the administrative process. ${ }^{238}$

90. According to the United States, whether requiring uniformity of administrative processes under Article X:3(a) would exclude de minimis variations in the administration of customs law is not at issue in this dispute. ${ }^{239}$ Indeed, the United States maintains that, where the Panel found divergences in administrative processes inconsistent with Article X:3(a), the divergences were material to traders' decisions to convey goods into the European Communities through one region rather than through another. $^{240}$

${ }^{233}$ United States' appellee's submission, para. 63 (referring to European Communities' other appellant's submission, para. 82).

${ }^{234}$ European Communities' other appellant's submission, para. 81.

${ }^{235}$ United States' appellee's submission, paras. 53-54.

${ }^{236}$ Ibid., para. 55.

${ }^{237}$ Ibid., para. 58.

${ }^{238}$ Ibid., para. 59.

${ }^{239} \mathrm{Ibid}$., paras. 60-61.

${ }^{240}$ Ibid., para. 61. 
(b) The Administrative Process Leading to the Tariff Classification of Blackout Drapery Lining

91. The United States submits that the Panel did not err in its findings regarding the tariff classification of blackout drapery lining. In the United States' view, the European Communities attempts to reargue certain factual issues, and in so doing misrepresents the relevant facts. ${ }^{241}$ The United States disagrees with the European Communities' assertion that the product considered by the German customs authorities in the instances of administration the Panel reviewed was different from the product considered by other customs authorities in other member States of the European Communities. ${ }^{242}$ Regarding the European Communities' allegation that the Panel was mistaken when it stated that all decisions or letters of the German customs authorities relied on an interpretative aid particular to Germany, the United States points out that there was an explicit reference to that aid in the documents issued by the German customs authorities. ${ }^{243}$ The United States requests the Appellate Body not to disturb the Panel's factual findings or reweigh the evidence that was before it. ${ }^{244}$

92. The United States asserts that the case of tariff classification of blackout drapery lining is a specific example of the European Communities' mistake of confusing administration as an ongoing phenomenon with individual acts of administration. For the United States, divergence in how the German customs authorities and customs authorities in other member States administer the Common Customs Tariff constitutes a lack of uniform administration. ${ }^{245}$

93. The United States argues that the Panel correctly found that non-uniform administrative processes in classifying blackout drapery lining are inconsistent with Article X:3(a). The United States observes that the Panel did not find that differences between the blackout drapery lining presented to the German customs authorities and the blackout drapery lining presented to other customs authorities in the European Communities justified different tariff classifications; rather, the United States asserts that what the Panel found was an absence of evidence to support a finding of divergent tariff classifications between Germany and the other member States. ${ }^{246}$ The United States contends that a finding of insufficient evidence of divergent classifications is not the same as a finding that different customs authorities correctly reached different tariff classifications. For the United States, the European Communities' argument regarding the classification of blackout drapery lining is

\footnotetext{
${ }^{241}$ United States' appellee's submission, para. 73.

${ }^{242}$ Ibid., para. 77.

${ }^{243}$ Ibid., para. 80.

${ }^{244}$ Ibid., para. 85.

${ }^{245}$ Ibid., para. 86.

${ }^{246}$ Ibid., para. 90.
} 
WT/DS315/AB/R

Page 38

a variation of its general argument that the obligation of uniform administration under Article X:3(a) covers administrative processes only to the extent that they have a direct and significant impact on administrative outcomes. ${ }^{247}$ Finally, according to the United States, the distinction the European Communities seeks to draw between the "motivation" of a decision and "administrative processes" is without basis. $^{248}$

94. The United States agrees with the Panel's finding that the German customs authorities failed to take into account the decisions of customs authorities of other member States regarding the classification of blackout drapery lining. ${ }^{249}$ For the United States, it is important to consider the context in which German customs authorities administer European Communities customs law, as it does not include any requirement of "reference by customs authorities to decisions taken by other customs authorities operating within the same system". ${ }^{250}$ The United States considers it important that "the German [customs] authority by its own admission was aware of other authorities [in the European Communities] having classified 'comparable goods', yet gave scant consideration to such classification and apparently undertook no investigation of those other authorities' findings."251

\section{(c) Tariff Classification of Liquid Crystal Display Monitors with Digital Video Interface}

95. The United States requests the Appellate Body to uphold the Panel's finding that the European Communities has violated Article X:3(a) of the GATT 1994 with respect to the tariff classification of LCD monitors with DVI. For the United States, the European Communities' claim misrepresents key facts and ignores the distinction between administration and evidence of administration. The United States also disagrees with the European Communities' argument that the Panel erred by declining to consider new evidence introduced following the issuance of the Panel's Interim Report. ${ }^{252}$

96. The United States submits that the Panel's finding that the European Communities acknowledged tariff classification of LCD monitors with DVI to be non-uniform in 2004 was based on an objective assessment of the facts. ${ }^{253}$ The United States emphasizes that it had established this fact before the Panel, and that various statements made by the European Communities in the course of

\footnotetext{
${ }^{247}$ United States' appellee's submission, para. 89.

${ }^{248}$ Ibid., para. 94.

${ }^{249}$ Ibid., para. 107.

${ }^{250}$ Ibid., para. 100 (quoting Panel Report, para. 7.272).

${ }^{251}$ Ibid., para. 102 (quoting Panel Report, paras. 7.273-7.274).

${ }^{252}$ Ibid., para. 108.

${ }^{253}$ Ibid., para. 109.
} 
the Panel proceedings suggested that the European Communities "was aware of the issue and was working to address it". ${ }^{254}$

97. The United States notes that the European Communities argued before the Panel that it had taken three steps to address the non-uniform administration with respect to the classification of LCD monitors with DVI: the June/July 2004 "conclusions" of the Customs Code Committee; Council Regulation (EC) No. 673/2005 of 25 April 2005 establishing additional customs duties on imports of certain products originating in the United States; and Commission Regulation (EC) No. 634/2005 of 26 April 2005 concerning the classification of certain goods in the Combined Nomenclature. ${ }^{255}$ The United States maintains that the Panel made an objective assessment of the facts as it considered each of these measures and found that none of them resolved the problem of non-uniform administration. ${ }^{256}$

98. For the United States, the Panel did not overstep its terms of reference by referring to acts of administration that post-dated the Panel's establishment, because the Panel did not refer to these acts as breaches of Article X:3(a) in their own right, but as evidence of the manner of administration in breach of Article X:3(a) that was in existence at the time the Panel was established. ${ }^{257}$ Thus, the United States argues, the European Communities again confuses administration with individual acts of administration. According to the United States, the Dutch decree of 8 July 2005 and the German BTI of 19 July 2005 are relevant evidence supporting the Panel's finding that "measures put into place since 2004 have not resolved the problem of non-uniform administration and may well have increased confusion." ${ }^{258}$

99. According to the United States, the Panel properly gave no weight to draft EC Regulation 2171/2005 concerning the tariff classification of LCD monitors and was correct to decline considering new evidence the European Communities introduced at the interim review stage. ${ }^{259}$ Regarding draft EC Regulation 2171/2005, the United States argues that the European Communities' characterization of this piece of evidence as a new instance, rather than a continuation, of non-uniform administration in existence since 2004 is unfounded, and that the Panel could not have assumed that this draft Regulation would be adopted. ${ }^{260}$ The United States adds that the European Communities' argument

${ }^{254}$ United States' appellee's submission, para. 110.

${ }^{255}$ Ibid., para. 117 (referring to European Communities' first written submission to the Panel, paras. 351-353, 356, and 361).

${ }^{256}$ Ibid., para. 123.

${ }^{257}$ Ibid., para. 125.

${ }^{258}$ Ibid., para. 126 (referring to Panel Report, para. 7.300).

${ }^{259}$ Ibid., paras. 128, 132, and 140 (referring, inter alia, to Exhibits EC-167, EC-168, and EC-169 submitted by the European Communities to the Panel).

${ }^{260}$ Ibid., paras. 129 and 131. 
WT/DS315/AB/R

Page 40

regarding the draft Regulation is "self-contradictory"261 because, on the one hand, it argues that the relevant point in time for establishing a violation is the date of panel establishment while, on the other hand, it faults the Panel for not taking account of draft EC Regulation 2171/2005, which came into existence late in the Panel proceedings. Regarding the Panel's decision not to consider new evidence introduced at the interim review stage, the United States emphasizes that the interim review stage is not an appropriate time to introduce new evidence, and disagrees with the European Communities' assertion that there should be an exception for evidence introduced to correct errors of fact. ${ }^{262}$

\section{Administration of the Successive Sales Provision}

100. The United States requests the Appellate Body to uphold the Panel's finding that the European Communities has violated Article X:3(a) of the GATT 1994 as a result of the imposition of a form of prior approval with respect to the successive sales provision by customs authorities of some member States of the European Communities. ${ }^{263}$

101. The United States asserts that the statement of the European Communities' Court of Auditors Report that, "in practice, some customs authorities do impose a form of prior approval even though this has no basis in [European] Communit[ies] law"264, amounts to an admission of non-uniform administration by the European Communities. ${ }^{265}$ With respect to the European Commission's comment on this statement in the Court of Auditors Report ${ }^{266}$, the United States submits that the European Communities has not accurately rendered the Commission's comment, because the words "in some member States" were omitted from the European Communities' quotation of the Commission's comment. In the United States' view, this reveals that the European Commission did not disagree with the Court of Auditors on the existence of divergent practices. ${ }^{267}$ For the United States, the very fact that, in its replies to the Court of Auditors Report, the Commission disagreed with the Court of Auditors on a variety of issues but not on the Court's finding of divergent administration among customs authorities of member States, supports the Panel's view that the Court's finding was an admission of non-uniform administration in the European Communities. ${ }^{268}$ The United States considers that it did not need to adduce additional evidence in order to establish its prima facie case,

${ }^{261}$ United States' appellee's submission, para. 130.

${ }^{262}$ Ibid., paras. 134-136. The United States makes reference to Appellate Body Report, EC - Sardines, para. 301, in support of its argument.

${ }^{263}$ United States' appellee's submission, para. 141.

${ }^{264}$ Court of Auditors Report, supra, footnote 207, para. 64; Panel Report, para. 7.381.

${ }^{265}$ United States' appellee's submission, para. 143.

${ }^{266}$ See supra, para. 79.

${ }^{267}$ United States' appellee's submission, para. 145.

${ }^{268}$ Ibid., para. 146. 
because it had provided the Panel with an admission of non-uniform administration by the European Communities.

102. The United States maintains that the Panel properly declined to consider evidence introduced by the European Communities at the interim review stage to rebut its admission of non-uniform administration, because this evidence could have been submitted at an earlier stage. Furthermore, according to the United States, even under the European Communities' own reasoning, it was proper for the Panel not to consider this new evidence concerning the administration of the successive sales provision, because the European Communities had not clarified that this evidence was intended merely to correct an error of fact. ${ }^{269}$ Finally, the United States alleges that the e-mail correspondence the European Communities sought to introduce at the interim review stage consisted of statements made by persons with a vested interest in the outcome of the dispute. ${ }^{270}$

\section{Conditional Appeal of the European Communities}

103. The United States requests the Appellate Body to reject the European Communities' conditional appeal to reverse the Panel's finding that Article XXIV:12 of the GATT 1994 cannot be relied upon to attenuate or to derogate from the provisions of the GATT 1994, including Article X:3. ${ }^{271}$

104. The United States asserts that the question of the possible relevance of Article XXIV:12 to the European Communities' obligations under Article X:3(b) is outside the scope of appellate review as circumscribed by Article 17.6 of the DSU. ${ }^{272}$ According to the United States, the European Communities never raised the issue of the relevance of Article XXIV:12 to its obligations under Article X:3(b), but referred to it only in relation to the obligation of uniform administration under Article X:3(a) of the GATT $1994 .^{273}$

105. The United States maintains that Article XXIV:12 of the GATT 1994 is not relevant to this dispute, because that provision applies to the "observance of the provisions of [the GATT 1994] by the regional and local governments and authorities within [each Member's] territories" whose measures "the federal government cannot control because they fall outside its jurisdiction under the

${ }^{269}$ United States' appellee's submission, para. 157.

${ }^{270}$ Ibid., para. 158.

${ }^{271}$ Ibid., para. 160; Panel Report, para. 7.145.

${ }^{272}$ United States' appellee's submission, para. 161.

${ }^{273}$ Ibid. (referring to European Communities' first written submission to the Panel, para. 220; and European Communities' response to Question 68 posed by the Panel, para. 113, Panel Report, pp. A-65 and A-66). 
WT/DS315/AB/R

Page 42

constitutional distribution of competences."274 In the United States' view, this dispute does not concern the observance of Article X:3(a) of the GATT 1994 by regional and local governments within the European Communities; but, rather, that the European Communities itself has failed to establish institutions or other mechanisms necessary to ensure uniform administration of its customs law. In this regard, the United States distinguishes the present dispute from the dispute in Canada - Gold Coins, which involved a measure adopted by a provincial government that put Canada in breach of its obligation under Article III of the GATT $1947 .{ }^{275}$

106. Finally, the United States argues that, even if Article XXIV:12 were applicable to this dispute, and even if it could potentially attenuate or derogate from the European Communities' obligations under Article X:3(a), it would not do so in this dispute, because the European Communities offered no evidence to show that the measures it is taking to ensure observance of Article X:3(a) by regional and local governments within its territories are "such reasonable measures as may be available to it", as required by Article XXIV:12. ${ }^{276}$ With respect to the European Communities' argument that the "safeguards and mechanisms"277 under its system of customs administration constitute such "reasonable measures", the United States submits that a mere assertion does not amount to proof, and that the question of whether the measures a Member is taking satisfy the requirements of Article XXIV:12 is not "self-judging". ${ }^{278}$

\section{E. Arguments of the Third Participants}

107. Pursuant to Rule 24(2) of the Working Procedures, Argentina, Australia, Brazil, China, Hong Kong, China, India, and the Separate Customs Territory of Taiwan, Penghu, Kinmen, and Matsu chose not to submit a third participant's submission but attended the oral hearing. In its statement at the oral hearing, Australia presented its views regarding the Panel's terms of reference, the interpretation of the scope of the term "administer" in Article X:3(a) of the GATT 1994, and the irrelevance of Article XXIV:12 of the GATT 1994 to the facts of this dispute. China, in its statement at the oral hearing, addressed issues relating to the Panel's terms of reference.

${ }^{274}$ United States' appellee's submission, paras. 164 and 163, respectively (referring to GATT Panel Report, Canada - Gold Coins, para. 56).

${ }^{275}$ Ibid., para. 164 (referring to European Communities' other appellant's submission, paras. 234 and 244).

${ }^{276}$ Ibid., para. 174.

${ }^{277}$ European Communities' other appellant's submission, para. 235.

${ }^{278}$ United States' appellee's submission, para. 174. 


\section{Japan}

108. Japan agrees with the Panel that "the measure at issue", for purposes of Article X:3(a) of the GATT 1994, can be the "manner of administration" rather than certain laws, regulations, decisions, and rulings themselves. ${ }^{279}$ According to Japan, previous WTO jurisprudence has indicated that "[i]n principle, any act or omission attributable to a WTO Member can be a measure of that Member for purposes of dispute settlement proceedings". ${ }^{280}$ Japan submits that the United States' distinction between a "measure" and a "claim" is not convincing. ${ }^{281}$ Japan considers that the manner of administration "can be described objectively" and that the "description of how a government administers laws, regulations and [other instruments] is nothing more than a description of an act or omission attributable to a WTO Member."282

109. Japan maintains that the Panel failed to provide sufficient reasoning for its finding that Article 6.2 of the DSU requires the complainant to identify specific areas of customs administration in the panel request, because the United States challenged before the Panel the administration of laws and regulations that cumulatively contain "thousands of different provisions". 283 Japan submits that the Panel's reasoning in this respect was insufficient, because "the Panel did not explain why the specification of the 'areas' of customs administration, each one of which still contains numerous different provisions to be administered, was sufficient to inform the defendant and the third parties of the legal basis of complaints." ${ }^{284}$ In Japan's view, the Panel also failed to explain why it relied on the Appellate Body's finding in EC - Computer Equipment, despite the differences between that case and the present case. Japan is of the opinion that the Panel ought to have provided "sufficient reasoning for its finding, since fixing the scope of the terms of reference of a panel is quite important in that it will directly affect the rights and obligations of the parties to disputes." 285

110. Japan also considers that the Panel failed to give due consideration to the European Communities' understanding of the claim against it in making findings on the scope and nature of the United States' challenge under Article X:3(a) of the European Communities' system of customs administration. ${ }^{286}$ Japan asserts that the Panel must give full effect to the specificity requirements in

${ }^{279}$ Japan's third participant's submission, paras. 8-17.

${ }^{280}$ Ibid., para. 11 (referring to Appellate Body Report, US - Corrosion-Resistant Steel Sunset Review, para. 81). (emphasis added by Japan)

${ }^{281}$ Ibid., para. 10.

${ }^{282}$ Ibid., para. 12.

${ }^{283}$ Ibid., para. 14; Panel Report, para. 7.30.

${ }^{284}$ Japan's third participant's submission, para. 16.

${ }^{285}$ Ibid., para. 17.

${ }^{286}$ Ibid., para. 18. 
WT/DS315/AB/R

Page 44

Article 6.2 of the DSU, and that it must assess whether or not the defendant was sufficiently informed of the legal basis of the claim against it.

111. Japan is "sceptical" about the Panel's finding that expired measures may properly be the subject of recommendations by a panel, since "it is practically impossible for a defendant to bring a measure into conformity with its WTO obligations when the measure is no longer in existence." ${ }^{287}$

112. With regard to the relevance of Article XXIV:12 of the GATT 1994 for the interpretation of Article X:3(a), Japan asserts that the Panel properly concluded that "Article XXIV:12 ... is drafted as a positive obligation rather than a defence", and that Article XXIV:12 "imposes an obligation on Members to take all reasonable measures to ensure that local authorities comply with WTO obligations." 288

\section{2. $\quad$ Korea}

113. Korea asserts that the Panel failed to take into account "the panel request of the United States, and the comments and arguments submitted during the underlying panel proceeding" ${ }^{289}$, which unequivocally challenged the European Communities' system of customs administration "as a whole" rather than individual instances of non-uniform customs administration. As a result, Korea argues, the Panel erroneously narrowed its terms of reference by addressing only the individual instances of alleged non-uniformity. Korea submits that "a panel must construe a panel request as a whole and ... it must consider how the different parts of a panel request relate to one another."290

114. With respect to the United States' claim concerning Article X:3(b) of the GATT 1994, Korea contends that the European Communities has failed to provide a mechanism for the prompt review and correction of administrative actions related to customs matters. Korea submits that the terms "the agencies" and "such agencies" without any qualification unambiguously refer to the collective government entity in charge of customs matters within a Member's territory. In addition, Korea submits that Article X:3(a) of the GATT 1994, when read as context to Article X:3(b) of the GATT 1994, indicates that the obligation contained in Article X:3(b) relates to all, rather than only to some, of the agencies. ${ }^{291}$

\footnotetext{
${ }^{287}$ Japan's third participant's submission, paras. 24 and 26 (referring to Panel Report, para. 7.36).

${ }^{288}$ Ibid., para. 28 (quoting Panel Report, para. 7.144).

${ }^{289}$ Korea's third participant's submission, para. 5.

${ }^{290}$ Ibid., para. 12. Korea makes reference to Appellate Body Report, US - FSC (Article 21.5 - EC II), paras. 66-68, and Appellate Body Report, US - Carbon Steel, para. 127, in support of its argument.

${ }^{291}$ Korea's third participant's submission, para. 18.
} 
115. Finally, Korea supports the United States' request that the Appellate Body complete the Panel's analysis and find that the European Communities' system of customs administration as a whole is inconsistent with the European Communities' obligation under Article X:3(a) of the GATT 1994. ${ }^{292}$ Korea also supports the United States' request that the Appellate Body complete the analysis with regard to Article X:3(b) of the GATT 1994 and find that the European Communities fails to provide review tribunals or procedures whose decisions govern the practice of "all the agencies entrusted with administrative enforcement" within the territory of the European Communities. $^{293}$

\section{Issues Raised in This Appeal}

116. The following issues are raised in this appeal:

(a) with respect to the Panel's terms of reference:

(i) whether the Panel erred in finding that the "measure at issue" for the purposes of a claim under Article X:3(a) of the GATT 1994 must necessarily be "the manner of administration that is allegedly non-uniform, partial and/or unreasonable" 294 ;

(ii) whether the Panel erred in finding that the specific measure at issue in this dispute is "the manner of administration ... of the Community Customs Code, the Implementing Regulation, the Common Customs Tariff, the TARIC and related measures"295, and, furthermore, that it was confined to "the areas of customs administration specifically identified in the United States' request for establishment of a panel" ${ }^{296}$;

(iii) whether the Panel erred in finding that, due to the wording and content of the panel request, it was precluded from considering "as such" challenges of the design and structure of the European Communities' system of customs administration as a whole or overall ${ }^{297}$; and

\footnotetext{
${ }^{292}$ Korea's third participant's submission, para. 14.

${ }^{293}$ Ibid., para. 20.

${ }^{294}$ Panel Report, para. 7.20.

${ }^{295}$ Ibid., para. 7.33. These laws and regulations are defined supra, para. 2 and footnote 2 thereto.

${ }^{296}$ Ibid., para. 7.64.

${ }^{297}$ Ibid., paras. 7.50, 7.63, and 7.64.
} 
WT/DS315/AB/R

Page 46

(iv) whether the Panel erred in its interpretation of the temporal scope of its terms of reference in respect of "steps and acts of administration that pre-date or post-date the establishment of a panel" ${ }^{298}$;

(b) with respect to Article X:3(a) of the GATT 1994:

(i) whether the Panel erred in finding that the term "administer" in Article X:3(a) of the GATT 1994 "relates to the application of laws and regulations, including administrative processes and their results, but not to laws and regulations as such" ${ }^{299}$, and whether, consequently, the Panel erred in finding that different penalty provisions and audit procedures found among the member States of the European Communities are not inconsistent with Article X:3(a) of the GATT $1994^{300}$;

(ii) whether the Panel has made an interpretation to the effect that Article X:3(a) of the GATT 1994 requires uniformity of "administrative processes"; whether the Panel erred in finding, in paragraph 7.119 of the Panel Report, that the term "administer" relates to administrative processes; and whether the Panel erred in finding that the administrative process leading to the tariff classification of blackout drapery lining amounts to non-uniform administration within the meaning of Article X:3(a) of the GATT 1994, and that the European Communities has violated Article X:3(a) of the GATT 1994 with respect to the tariff classification of blackout drapery lining $^{301}$;

(iii) whether the Panel erred in finding that the European Communities has violated Article X:3(a) of the GATT 1994 with respect to the tariff classification of liquid crystal display flat monitors with a digital video interface ${ }^{302}$;

\footnotetext{
${ }^{298}$ Panel Report, paras. 7.36-7.37.

${ }^{299}$ Ibid., para. 7.119.

${ }^{300}$ Ibid., paras. 7.434 and 7.444.

${ }^{301}$ Ibid., para. 7.276.

${ }^{302}$ Ibid., para. 7.305 .
} 
(iv) whether the Panel erred in finding that the European Communities' administration of the "successive sales provision"303 amounts to a violation of Article X:3(a) of the GATT 1994 because some member States of the European Communities impose a "form of prior approval" requirement while others do not ${ }^{304}$; and

(v) in the event that the Appellate Body concludes that the Panel erred in its identification of the specific measures at issue in this dispute, and in the event that the Appellate Body concludes that the United States was not precluded from challenging the European Communities' system of customs administration as a whole or overall, whether the Appellate Body is in a position to complete the analysis regarding this claim;

(c) with respect to Article X:3(b) of the GATT 1994:

whether the Panel erred in finding that "Article X:3(b) [of the GATT 1994] does not necessarily mean that the decisions of the judicial, arbitral or administrative tribunals or procedures for the review and correction of administrative action relating to customs matters must govern the practice of all the agencies entrusted with administrative enforcement throughout the territory of a particular [WTO] Member" ${ }^{1305}$; and

(d) with respect to Article XXIV:12 of the GATT 1994:

in the event that the conditions posited by the European Communities' appeal are fulfilled, whether the Panel erred in its interpretation of Article XXIV:12 of the GATT $1994 .^{306}$

117. We proceed to analyze these issues in the order set out above.

\footnotetext{
${ }^{303}$ Article $147(1)$ of the Implementing Regulation.

${ }^{304}$ Panel Report, para. 7.385.

${ }^{305}$ Ibid., paras. 7.539, 7.556, and 8.1(e). (original emphasis)

${ }^{306}$ Ibid., para. 7.145 .
} 
WT/DS315/AB/R

Page 48

\section{The Panel's Terms of Reference}

118. With respect to the Panel's terms of reference, the United States' appeal can be divided into three issues.

119. The first issue raised is whether the Panel erred in finding that, "when a violation of Article X:3(a) of the GATT 1994 is being claimed, the relevant request for establishment of a panel must identify the manner of administration that is allegedly non-uniform, partial and/or unreasonable." ${ }^{1307}$ (infra, Section IV.A) The second issue is whether the Panel erred in finding that the specific measure at issue in this dispute is "the manner of administration ... of the Community Customs Code, the Implementing Regulation, the Common Customs Tariff, the TARIC and related measures" and, furthermore, that it was confined to the six areas of customs administration specifically identified in the third paragraph of the request for the establishment of a panel by the United States (the "panel request"). ${ }^{308}$ (infra, Section IV.B) While these two issues relate to the identification of the specific measure at issue, the third issue raised by the United States relates to the Panel's construction of the nature and scope of the claim set out in the panel request. With respect to this third issue, the United States contends that the Panel erred in finding that, due to the wording and content of the panel request, the United States was precluded from challenging the European Communities' system of customs administration "as a whole" or "as such". (infra, Section IV.C)

120. In its other appeal, the European Communities contends that the Panel erred in its interpretation of the temporal scope and limitations of its terms of reference in respect of "steps and acts of administration that pre-date or post-date the establishment of a panel". ${ }^{309}$ (infra, Section IV.D)

121. We now examine these four issues in detail.

\section{A. Interpretation of the Term "Measures at Issue" under Article 6.2 of the DSU}

122. The first issue is whether the Panel erred in finding that the "measure at issue" for purposes of a claim under Article X:3(a) of the GATT 1994 must be the "manner of administration" that is allegedly non-uniform, partial, and/or unreasonable. ${ }^{310}$

\footnotetext{
${ }^{307}$ Panel Report, para. 7.20.

${ }^{308}$ Ibid., para. 7.33.

${ }^{309}$ Ibid., para. 7.37.

${ }^{310}$ Ibid., paras. 7.20 and 7.22 .
} 
123. The Panel was of the view that the term "measures at issue" in Article 6.2 of the DSU should be interpreted in the light of the specific WTO obligation that is allegedly being violated by that measure in a particular dispute. The Panel considered that this approach is necessary because the "measure at issue" identified in the panel request will be the subject of a recommendation, pursuant to Article 19.1 of the DSU, if that measure is found to be in violation of a WTO obligation. ${ }^{311}$

124. Based on this general proposition, the Panel turned to the interpretation of the nature of a "measure at issue" with respect to the obligation contained in Article X:3(a) of the GATT 1994. The Panel considered that the essence of the obligation under this Article is to "administer [the legal instruments of the kind described in Article X:1] in a uniform, impartial and reasonable manner". ${ }^{312}$ For the Panel, "this essential aspect of the obligation contained in Article X:3(a) of the GATT 1994 [implies that] when a violation of Article X:3(a) of the GATT 1994 is being claimed, the ... request for establishment of a panel must identify the manner of administration that is allegedly non-uniform, partial and/or unreasonable." ${ }^{313}$ The Panel further reasoned that, if a WTO Member were found to be in violation of Article X:3(a), this would mean that the manner in which the legal instruments are being administered by that Member is not uniform, impartial, or reasonable. In order to comply with a recommendation made under Article 19.1 of the DSU to bring the measure at issue into conformity with Article X:3(a) of the GATT 1994, "the Member would need to alter the manner in which the relevant laws, regulations, decisions and/or rulings are being administered ". ${ }^{314}$ Thus, for the Panel, the specific WTO obligation alleged to be violated and the means of compliance with a recommendation made under Article 19.1 of the DSU should govern the identification of the specific measure at issue under Article 6.2 of the DSU. The Panel therefore found that, for purposes of a claim under Article X:3(a), the "measure at issue" to be identified in the panel request under Article 6.2 of the DSU must be the "manner of administration" of the legal instruments of the kind described in Article X:1 of the GATT 1994. ${ }^{315}$

125. On appeal, the United States challenges this interpretation of the Panel. For the United States, "manner of administration" is not a "measure" ${ }^{136}$; rather, it is, "[a]s the Panel uses the term, ... a description of how a measure operates so as to breach an Agreement provision." ${ }^{317}$ The United States

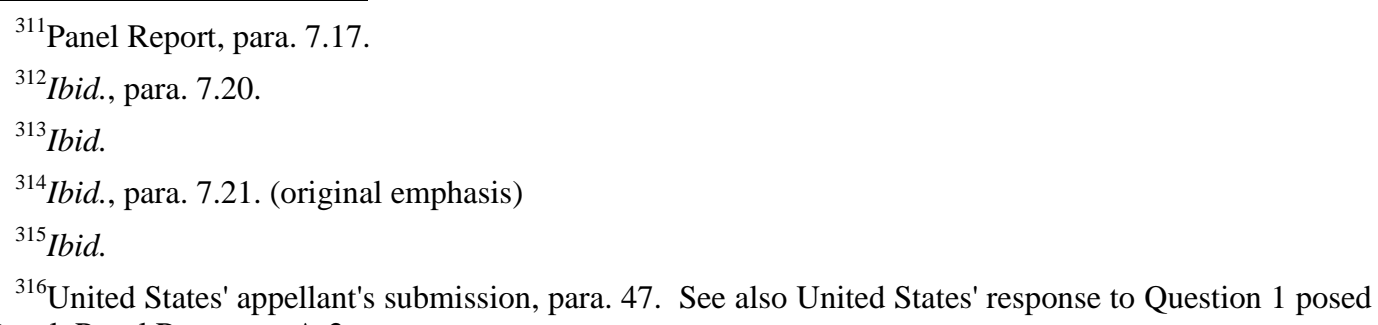
by the Panel, Panel Report, p. A-2.

${ }^{317}$ United States' appellant's submission, para. 47. (original emphasis) 
WT/DS315/AB/R

Page 50

emphasizes that the Panel's reasoning blurs the distinction between "measures" and "claims". ${ }^{318}$ The United States also finds fault with the Panel's recourse to Article 19.1 of the DSU in identifying the measure at issue. The United States point out that, "because DSU Article 19.1 requires that the breaching 'measure' be brought into conformity", it does not follow that "the measure in the case of Article X:3(a) must be the 'manner of administration' of 'laws, regulations, judicial decisions or administrative rulings,' rather than the laws, regulations, judicial decisions, or administrative rulings themselves." ${ }^{319}$ For the United States, "[t]he mere fact that a breach of Article X:3(a) may be removed by changing a law's administration is not a basis for concluding that the law is not the measure at issue." ${ }^{320}$ The United States also argues that the Panel's reasoning leads to illogical consequences for complaints not only under Article X:3(a) of the GATT 1994 but under other WTO provisions as well, because, under this approach, the measure at issue will not be "distinguishable" from the legal basis of the complaint, namely, the claim under Article 6.2 of the DSU. ${ }^{321}$

126. The European Communities agrees with the Panel that the measure at issue with respect to the United States' claim under Article X:3(a) in this dispute is the "manner of administration" of European Communities customs law. ${ }^{322}$ The European Communities argues that, by referring to the "manner of administration", the Panel did not blur the distinction between the measure at issue and the claim under Article X:3(a). According to the European Communities, the Panel used the term "manner of administration" to distinguish "administration"—which is the measure at issue under Article X:3(a)— from the laws, regulations, judicial decisions, and administrative rulings of general application under Article X:1 of the GATT 1994, which are the subject of administration. ${ }^{323}$ The European Communities is of the view that the Panel used the term "manner of administration" synonymously with "administration" ${ }^{224}$, and submits that this "minor ambiguity"325 is not enough to reverse the Panel's finding that, when a violation of Article X:3(a) is claimed, the panel request must identify the "manner of administration". The European Communities contends that the United States is trying to confuse the laws to be administered with their administration. ${ }^{326}$ The European Communities points out that the panel request itself refers specifically to the manner of administration ${ }^{327}$, "clearly

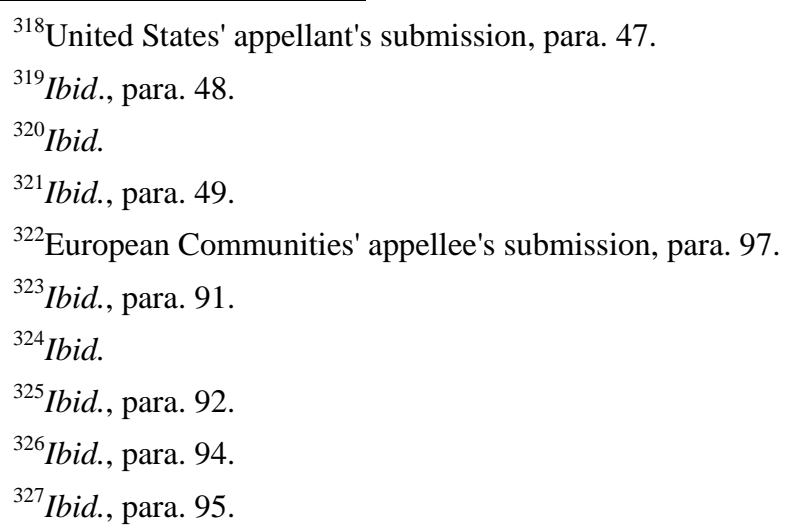


distinguishes the administration from the laws which are being administered" ${ }^{328}$, and, thus, "identifies the 'administration', rather than [the] laws, as the measure at issue in the dispute". ${ }^{329}$

127. We are thus called upon to determine whether the Panel erred in finding that, when a violation of Article X:3(a) of the GATT 1994 is being claimed, the "measure at issue" must necessarily be the "manner of administration" of the legal instruments of the kind described in Article X:1, and that such legal instruments cannot themselves be identified as the "measures at issue".

128. We begin our analysis with the text of Article 6.2 of the DSU, which provides:

The request for the establishment of a panel shall be made in writing. It shall indicate whether consultations were held, identify the specific measures at issue and provide a brief summary of the legal basis of the complaint sufficient to present the problem clearly. In case the applicant requests the establishment of a panel with other than standard terms of reference, the written request shall include the proposed text of special terms of reference.

129. Article 6.2 sets forth the requirements applicable to a request for the establishment of a panel. As the Appellate Body stated in US - Carbon Steel, there are two distinct requirements, namely:

... identification of the specific measures at issue, and the provision of a brief summary of the legal basis of the complaint (or the claims). ${ }^{330}$ (original emphasis)

130. These two requirements relate to different aspects of the complainant's challenge to measures taken by another Member. The "specific measure" to be identified in a panel request is the object of the challenge, namely, the measure that is alleged to be causing the violation of an obligation contained in a covered agreement. In other words, the measure at issue is what is being challenged by the complaining Member. In contrast, the legal basis of the complaint, namely, the "claim" pertains to the specific provision of the covered agreement that contains the obligation alleged to be violated. A brief summary of the legal basis of the complaint required by Article 6.2 of the DSU aims to explain succinctly how or why the measure at issue is considered by the complaining Member to be violating the WTO obligation in question. This brief summary must be sufficient to present the problem clearly. Taken together, these different aspects of a panel request serve not only to define the scope of a dispute, but also to meet the due process requirements.

\footnotetext{
${ }^{328}$ European Communities' appellee's submission, para. 96.

${ }^{329}$ Ibid.

${ }^{330}$ Appellate Body Report, US - Carbon Steel, para. 125.
} 
WT/DS315/AB/R

Page 52

131. Pursuant to Article 7.1 of the DSU, a panel's terms of reference are governed by the request for the establishment of a panel. In other words, the panel request identifies the measures and the claims that a panel will have the authority to examine and on which it will have the authority to make findings. The question of whether a measure falls within a panel's terms of reference is a threshold issue, distinct from the question of whether the measure is consistent or not with the legal provision(s) of the covered agreement(s) to which the panel request refers. Therefore, questions pertaining to the identification of the "measures at issue" and the "claims" relating to alleged violation of WTO obligations, set out in a panel request, should be analyzed separately.

132. At the heart of the Panel's reasoning stands the proposition that the term "measure at issue" in Article 6.2 of the DSU should be interpreted in the light of the specific WTO obligation that is raised in a particular claim. This reasoning appears to us to be flawed. The Panel's proposition would introduce uncertainty because the identification of the measure would vary depending on the substance of the legal provision invoked by a complainant and the interpretation that a panel might give to that provision. As we noted above, Article 6.2 of the DSU sets out "two distinct requirements" applicable to requests for the establishment of a panel: "identification of the specific measures at issue, and the provision of a brief summary of the legal basis of the complaint (or the claims)" sufficient to present the problem clearly. ${ }^{331}$ These two requirements are conceptually different and they should not be confused. In finding that the term "measures at issue" in Article 6.2 should be interpreted in the light of the specific WTO obligation that is alleged to be violated, the Panel blurred the distinction between measures and claims.

133. In our view, a complainant is entitled to include in its panel request an allegation of inconsistency with a covered agreement of any measure that may be submitted to WTO dispute settlement. In US - Corrosion-Resistant Steel Sunset Review, the Appellate Body provided guidance on the types of measures that may be the subject of dispute settlement. Relying on, inter alia, Article 3.3 of the DSU, which refers to "situations in which a Member considers that any benefits accruing to it directly or indirectly under the covered agreements are being impaired by measures taken by another Member", the Appellate Body stated that "[i]n principle, any act or omission attributable to a WTO Member can be a measure of that Member for purposes of dispute settlement proceedings." ${ }^{332}$ As long as the specificity requirements of Article 6.2 are met, we see no reason why a Member should be precluded from setting out in a panel request "any act or omission" attributable to another Member as the measure at issue.

\footnotetext{
${ }^{331}$ Appellate Body Report, US - Carbon Steel, para. 125. (original emphasis)

${ }^{332}$ Appellate Body Report, US - Corrosion-Resistant Steel Sunset Review, para. 81. (emphasis added; footnote omitted)
} 
134. The Panel considered that, when a violation of Article X:3(a) of the GATT 1994 is claimed, the measure at issue must necessarily be a "manner of administration" because, if such a violation is found, the WTO Member concerned would need to alter the manner of administration in order to comply with a recommendation made pursuant to Article 19.1 of the DSU. In our view, this reasoning of the Panel is flawed because it conflates the threshold question of whether a measure falls within a panel's terms of reference with the question of the means of implementation in the event that a violation is found. Through the recommendation under Article 19.1, the Member found to have violated a provision of a covered agreement is required to take corrective action to remove the violation. The recommendation envisaged in Article 19.1 concerns the stage of implementation and not the question of whether a measure falls within a panel's terms of reference. Moreover, the Member concerned has a degree of discretion with respect to the nature and type of action that it undertakes in order to achieve compliance. Therefore, we have difficulty in understanding how the means of compliance with a recommendation under Article 19.1 of the DSU should govern the identification of the specific measure at issue in a panel request. We agree, in this respect, with the United States that "[t]he mere fact that a breach of Article X:3(a) may be removed by changing a law's administration is not a basis for concluding that the law is not the measure at issue."333

135. In US - Upland Cotton, the Appellate Body emphasized that the nature of a recommendation a panel may make under Article 19.1 of the DSU with respect to a measure "is not ... dispositive of the preliminary question of whether a panel can address claims in respect of that measure". ${ }^{334}$ In that case, the Appellate Body had to address the issue of whether an expired measure can be a "measure at issue" within the meaning of Article 6.2 of the DSU. The Appellate Body rejected the United States' argument that, because an expired measure is not susceptible to a recommendation under Article 19.1 of the DSU, it cannot be a "measure at issue" under Article 6.2. For the Appellate Body, the question of whether a panel can address claims in respect of an expired measure is to be distinguished from the question of whether that measure is susceptible to a recommendation under Article 19.1. ${ }^{335}$ Although the issue addressed by the Appellate Body in US - Upland Cotton is not identical to that raised by the United States' appeal in this case, the Appellate Body's reasoning in US - Upland Cotton supports our position that Article 19.1 of the DSU does not place restrictions on the type of measure that can be identified in a panel request under Article 6.2 of the DSU.

\footnotetext{
${ }^{333}$ United States' appellant's submission, para. 48.

${ }^{334}$ Appellate Body Report, US - Upland Cotton, para. 272. (footnote omitted)

${ }^{335}$ Ibid., para. 222.
} 
WT/DS315/AB/R

Page 54

136. Interpreting the term "measure at issue" in Article 6.2 of the DSU in the light of the substance of the specific WTO obligation that is allegedly being violated ${ }^{336}$ would generate uncertainty and complexity in WTO dispute settlement proceedings. When drafting a request for the establishment of a panel, the complainant would have to foresee the possible restrictions that the substance of the legal provisions might impose on the type of measure that could be challenged. The identification of the measures at issue in the panel request might prove to be even more complex where the challenge concerns a plurality of provisions of the covered agreements. Moreover, the existence, nature, and scope of possible restrictions would depend on the panel's interpretation of the substance of those legal provisions. The respondent might also be placed in an uncertain situation in presenting its defence because it would have to guess what the panel would identify as the measure at issue on the basis of the panel's interpretation of the substance of the alleged violation. This could lead to unnecessary litigation on a panel's terms of reference, as the responding party may choose to contend at a preliminary stage that, in the light of the substance of the legal provision on which a specific claim is based, the measure identified in the panel request does not fall within the panel's terms of reference.

137. In the light of these considerations, we reverse the Panel's finding, in paragraph 7.20 of the Panel Report, that the "measure at issue" for purposes of a claim under Article X:3(a) of the GATT 1994 must necessarily be "the manner of administration that is allegedly non-uniform, partial and/or unreasonable."

\section{B. Confinement of the Measures at Issue to Areas of Customs Administration}

138. We next address the issue of whether the Panel erred in finding that the specific measure at issue in this dispute was "the manner of administration ... of the Community Customs Code, the Implementing Regulation, the Common Customs Tariff, the TARIC and related measures" ${ }^{133}$, and furthermore, that it was confined to the areas of customs administration identified in the third paragraph of the panel request.

139. In the first paragraph of the panel request, the United States stated that it "considers that the manner in which the European Communities ... administers its laws, regulations, decisions and rulings of the kind described in Article X:1 of the ... GATT 1994 ... is not uniform, impartial and reasonable, and therefore is inconsistent with Article X:3(a) of the GATT 1994." ${ }^{338}$ Also, in the third paragraph

\footnotetext{
${ }^{336}$ Panel Report, para. 7.17.

${ }^{337}$ Ibid., para. 7.33.

${ }^{338}$ Request for the Establishment of a Panel by the United States (attached as Annex III to this Report),
}

p. 1. 
of the panel request, the United States asserted that the lack of uniform, impartial, and reasonable administration of measures relating to customs matters is manifest in differences among member States of the European Communities in a number of areas. The United States went on to state that these areas include, but are not limited to:

- classification and valuation of goods;

- procedures for the classification and valuation of goods, including the provision of binding classification and valuation information to importers;

- procedures for the entry and release of goods, including different certificate of origin requirements, different criteria among member States for the physical inspection of goods, different licensing requirements for importation of food products, and different procedures for processing express delivery shipments;

- procedures for auditing entry statements after goods are released into the stream of commerce in the European Communities;

- $\quad$ penalties and procedures regarding the imposition of penalties for violation of customs rules; and

- $\quad$ record-keeping requirements. ${ }^{339}$

140. The Panel was of the view that "[t]he terms of the United States' request for establishment of a panel indicate that it challenges the manner of administration of certain aspects of [European Communities] customs law." ${ }^{340}$ According to the Panel, "[t]he request clarifies that the administration challenged by the United States is that undertaken by the 'national customs authorities of [European Communities] member States'", and that "the specific forms of administration by national customs authorities challenged by the United States under Article X:3(a) of the GATT 1994 include, inter alia, laws, regulations, handbooks, manuals and administrative practices." ${ }^{341}$

141. The Panel stated that "the requirements in Article 6.2 of the DSU, including the obligation to specifically identify the 'measure at issue', serve the important due process objective of notifying the parties and third parties to a dispute of the nature of the complainant's case". ${ }^{342}$ The Panel noted that the United States had challenged measures that "cumulatively contain, literally, thousands of different provisions [that] relate to a vast array of different customs areas, and may entail administration in a

\footnotetext{
${ }^{339}$ Request for the Establishment of a Panel by the United States, p. 2.

${ }^{340}$ Panel Report, para. 7.25.

${ }^{341}$ Ibid.

${ }^{342}$ Ibid., para. 7.27. (original emphasis)
} 
WT/DS315/AB/R

Page 56

multitude of diverse ways." ${ }^{\text {"343 }}$ In the light of this, the Panel considered that, "in the context of this dispute, the specificity requirement in Article 6.2 of the DSU additionally requires the identification of the customs areas in the context of which the obligation contained in Article X:3(a) of the GATT 1994 is alleged by the United States to be violated", because "without such additional specificity regarding the customs areas at issue, the European Communities would not have been accorded its due process right to be informed of the nature of the United States' claim under Article X:3(a) of the GATT 1994." ${ }^{344}$

142. Also, the Panel drew an analogy with the Appellate Body Report in EC - Computer Equipment, where the Appellate Body noted that, even though "Article 6.2 does not explicitly require that the products to which the 'specific measures' at issue apply be identified ... with respect to certain WTO obligations, in order to identify 'the specific measures at issue', it may ... be necessary to identify the products subject to the measures in dispute". ${ }^{345}$ According to the Panel, because, in the context of the present case, the "measure at issue" is the manner of administration of instruments relating to customs matters, the "identification of the areas of customs administration at issue is necessary to specifically identify the 'measures at issue' in the same way as suggested by the Appellate Body in EC - Computer Equipment" with respect to the products subject to the measure at issue in that case. ${ }^{346}$

143. The Panel noted:

[T] he list of the areas of customs administration contained in the United States' request for establishment of a panel is preceded by the following text: "Lack of uniform, impartial and reasonable administration of the above-identified measures is manifest in differences among member States in a number of areas, including, but not limited to, the following ...". ${ }^{347}$ (emphasis added by the Panel)

However, the Panel was of the view that the phrase "including, but not limited to" on its own does not have the legal effect of incorporating into the Panel's terms of reference all areas of customs administration in the European Communities' system of customs administration, in addition to those specifically identified in the panel request. For the Panel, interpreting that phrase as having the legal effect of including areas not specifically identified in the panel request "would undermine an important due process objective of the requirements of Article 6.2 of the DSU-namely, to provide

\footnotetext{
${ }^{343}$ Panel Report, para. 7.30.

${ }^{344}$ Ibid.

${ }^{345}$ Appellate Body Report, EC - Computer Equipment, para. 67. (original emphasis)

${ }^{346}$ Panel Report, para. 7.31. (original emphasis)

${ }^{347}$ Ibid., para. 7.49 .
} 
sufficient notice and information to the responding party and third parties to a dispute of the nature of the complainant's case." ${ }^{348}$

144. On this basis, the Panel concluded:

[T] he United States' request for establishment of a panel indicates that the "specific measure at issue" in this dispute for the purposes of Article 6.2 of the DSU is the manner of administration by the national customs authorities of the member States of the Community Customs Code, the Implementing Regulation, the Common Customs Tariff, the TARIC and related measures in the areas of customs administration specifically identified in the United States' request for establishment of a panel - namely, the classification and valuation of goods, procedures for the classification and valuation of goods, procedures for the entry and release of goods, procedures for auditing entry statements after goods are released into free circulation, penalties and procedures regarding the imposition of penalties for violation of customs rules and record-keeping requirements. ${ }^{349}$

145. On appeal, the United States contends that the Panel erred in finding the specific measure at issue to be confined to areas of customs administration listed in the panel request, because the Panel failed to construe the panel request as a whole. ${ }^{350}$ The United States also argues that the Panel confused arguments, on the one hand, with measures and claims, on the other hand. ${ }^{351}$ For the United States, had the Panel construed the panel request as a whole, it could not have avoided the conclusion that, first, the specific measures at issue were the Community Customs Code, the Implementing Regulation, the Tariff Regulation, the TARIC, and, for each of these instruments, all amendments, "implementing measures, and other related measures"; and secondly, that the legal basis of the complaint was the administration of those measures in a manner inconsistent with Article X:3(a) of the GATT $1994{ }^{352}$ The United States emphasizes that the list of areas provided in the third paragraph of the panel request was merely illustrative, aimed to give an indication of the argument underlying the United States' claim, and did not constitute the claim itself or the specific measure at issue. ${ }^{353}$ According to the United States, the Panel made a selective reading of the panel request, focusing on particular text taken out of its context. ${ }^{354}$ The Panel's characterization of the illustrative list as a specification of the measures at issue "ignored the introduction to the list, which stated that '[1]ack of

\footnotetext{
${ }^{348}$ Panel Report, para. 7.49

${ }^{349}$ Ibid., para. 7.33.

${ }^{350}$ These areas of customs administration are presented supra, para. 139.

${ }^{351}$ United States' appellant's submission, paras. 52 and 66.

${ }^{352}$ Ibid., paras. 54-55.

${ }^{353}$ Ibid., para. 57.

${ }^{354}$ Ibid., para. 58.
} 
WT/DS315/AB/R

Page 58

uniform, impartial and reasonable administration of the above-identified measures is manifest in differences among member States in a number of areas, including, but not limited to, the following."'355 The United States argues that such a listing of the areas was not required; the list merely made the panel request more transparent, in that it anticipated certain arguments the United States would make in its submissions and statements to substantiate its claims.

146. The United States also argues that "the Panel gave no consideration to the fact that the request included a claim that the absence of mechanisms or institutions in the European Communities' system of customs administration as a whole results in the non-uniform administration of the measures at issue, in breach of Article X:3(a) of the GATT 1994." ${ }^{356}$ The United States considers that the Panel erred in drawing an analogy between the EC-Computer Equipment dispute and the present case because, in EC-Computer Equipment, the scope of the measures at issue depended on the identity of the products subject to the measures; also, the claim put forward in that case was not "systemic" and did not relate to a system as a whole. ${ }^{357}$ In these respects, EC - Computer Equipment is to be distinguished from this case.

147. For the European Communities, the Panel correctly concluded that the measure at issue was only the administration of European Communities customs law in the areas identified in the third paragraph of the panel request. The European Communities asserts that, in this case, the measure at issue is not the set of legal instruments listed in the first paragraph of the panel request but, rather, their administration. ${ }^{358}$ The European Communities submits that the United States attempts to engage a selective reading of the panel request by asking the Appellate Body to ignore the third paragraph of the panel request. ${ }^{359}$ Furthermore, given the "vast body of law" ${ }^{360}$ referred to by the United States in the first paragraph of the panel request, it would not have been possible for the European Communities to prepare adequately its defence purely on the basis of a challenge against the administration of European Communities customs law "as a whole" without an indication of the relevant provisions or sectors. In the view of the European Communities, "an identification of the specific issue or provision with respect to which a claim of non-uniform administration is made was ... necessary to protect ... [its] due process rights." ${ }^{361}$

\footnotetext{
${ }^{355}$ United States' appellant's submission, para. 59.

${ }^{356}$ Ibid., para. 61.

${ }^{357}$ Ibid., para. 62.

${ }^{358}$ European Communities' appellee's submission, para. 99.

${ }^{359}$ Ibid., para. 100.

${ }^{360}$ Ibid., para. 103.

${ }^{361}$ Ibid.
} 
148. The European Communities contends that the Panel correctly referred to the general principle set out in the Appellate Body Report in EC - Computer Equipment that "what is necessary for identification of the 'specific measures at issue' depends on the circumstances of the case." ${ }^{362}$ In the circumstances of the present case, given the vast body of law to which the United States referred, the Panel was justified in requiring specification of areas of customs administration. Regarding the terms "including but not limited to" contained in the third paragraph of the panel request, the European Communities relies on the Appellate Body Report in India - Patents (US) in asserting that "these words cannot have the effect of including, contrary to the requirements of Article 6.2 of the DSU, the administration of the entire body of [European Communities] customs law into the Panel's terms of reference." ${ }^{363}$ The European Communities adds that the United States' interpretation of this phrase would reduce the third paragraph of the panel request to inutility ${ }^{364}$ and would "prejudice its due process rights by leaving the actual subject matter of the case unclear". ${ }^{365}$

149. We begin our analysis by recalling that, "[i]n principle, any act or omission attributable to a WTO Member can be a measure of that Member for purposes of dispute settlement proceedings." 366 Under Article 6.2 of the DSU, a complaining Member enjoys certain discretion in the identification of the specific measure at issue. Having said this, we must determine what is identified in the panel request as the specific measure at issue in this case.

150. We note that the first paragraph of the panel request contains a list of instruments, introduced by the phrase "[t]he measures consist of:" The United States lists the following instruments:

- Council Regulation (EEC) No. 2913/92 of 12 October 1992 establishing the Community Customs Code, including all annexes thereto, as amended (the "Community Customs Code");

- Commission Regulation (EEC) No. 2454/93 of 2 July 1993 laying down provisions for the implementation of Council Regulation (EEC) No 2913/92 of 12 October 1992 establishing the Community Customs Code, including all annexes thereto, as amended (the "Implementing Regulation");

\footnotetext{
${ }^{362}$ European Communities' appellee's submission, para. 105.

${ }^{363}$ Ibid., para. 106.

${ }^{364}$ Ibid., para. 108.

${ }^{365}$ Ibid., para. 109.

${ }^{366}$ Appellate Body Report, US - Corrosion-Resistant Steel Sunset Review, para. 81. (footnote omitted)
} 
WT/DS315/AB/R

Page 60

- Council Regulation (EEC) No. 2658/87 of 23 July 1987 on the tariff and statistical nomenclature and on the Common Customs Tariff, including all annexes thereto, as amended (the "Common Customs Tariff");

- the Integrated Tariff of the European Communities established by virtue of Article 2 of Council Regulation (EEC) No. 2658/87 of 23 July 1987 on the tariff and statistical nomenclature and on the Common Customs Tariff, including all annexes thereto, as amended (the "TARIC"); and

- for each of the above laws and regulations ${ }^{367}$, all amendments, "implementing measures and other related measures".

Subsequently, in the panel request, the United States referred to the instruments listed in the first paragraph with the expressions "these measures" (in the second paragraph of the panel request) and "the above-identified measures" (in the third and fourth paragraphs).

151. We further note, as the Panel did, that the panel request refers repeatedly and consistently to the administration of the legal instruments listed in the first paragraph of the panel request. The panel request begins by stating that the United States "considers that the manner in which the European Communities ... administers its laws, regulations, decisions and rulings of the kind described in Article X:1 of the ... GATT 1994". (emphasis added) In the second sentence of the first paragraph, the United States submits that "the European Communities fails to administer", in a manner consistent with Article X:3(a), the legal instruments cited therein. (emphasis added) The second paragraph of the panel request, in each of its sentences, also refers to the "administration" of the legal instruments listed in the first paragraph; so does the introductory sentence of the third paragraph of the panel request. Thus, the panel request makes it clear that the United States does not challenge under Article X:3(a) the substantive content of the legal instruments listed in the first paragraph of the panel request, but their administration collectively. The United States confirmed at the oral hearing that it had challenged under Article X:3(a) these legal instruments as administered collectively. ${ }^{368}$

\footnotetext{
${ }^{367}$ These laws and regulations are defined supra, para. 2 and footnote 2 thereto.

${ }^{368}$ See also United States' responses to Questions 1 and 4 posed by the Panel, Panel Report, pp. A-1 and A-4. In its response to Question 1, the United States stated that, "[i]n this dispute, the United States is challenging the manner in which [European Communities] customs law is administered." (emphasis added) In its response to Question 4, the United States explained that it is, "indeed, challenging the absence of uniformity overall with respect to the administration of the [European Communities'] customs system." (emphasis added)
} 
152. We recall that Article 6.2 of the DSU requires the identification of the "specific measures at issue" in the request for the establishment of a panel. The word "specific" in Article 6.2 establishes a specificity requirement regarding the identification of the measures that serves the due process objective of notifying the parties and the third parties of the measure(s) that constitute the object of the complaint. We therefore examine the question whether the presentation in the panel request meets the specificity requirement in Article 6.2 of the DSU. In our view, this specificity requirement is met with respect to the Community Customs Code, the Implementing Regulation, the Common Customs Tariff, and the TARIC. For each of these instruments, a specific citation is provided. Also, the panel request indicates clearly that the United States was challenging the manner in which these legal instruments are administered collectively. In our view, the first paragraph of the panel request is sufficiently specific to give notice to the parties and the third parties of the measures that constitute the object of the complaint. ${ }^{369}$

153. We turn next to the question whether the panel request confines the measure at issue to areas of customs administration. We read the third paragraph of the panel request as an illustrative list of areas where the United States considers European Communities customs law is not administered in a uniform way. Thus, the substance of the third paragraph of the panel request should be viewed as an anticipation of the United States' arguments. In this paragraph, the United States explains-briefly and in general terms - why it considers that the legal instruments listed in the first paragraph of the panel request are administered in a manner that is inconsistent with the uniformity requirement in Article X:3(a). Article 6.2 of the DSU requires that the claims—not the arguments-be set out in a panel request in a way that is sufficient to present the problem clearly. ${ }^{370}$ Nothing in Article 6.2 prevents a complainant from making statements in the panel request that foreshadow its arguments in substantiating the claim. If the complainant chooses to do so, these arguments should not be interpreted to narrow the scope of the measures or the claims. Accordingly, we are of the opinion that the Panel erred when it found that the list of areas of customs administration in the third paragraph of the panel request limits the scope of the "specific measures at issue". ${ }^{371}$

\footnotetext{
${ }^{369}$ We observe that the first paragraph of the panel request also lists among the measures at issue the "implementing measures and other related measures" for the Community Customs Code, the Implementing Regulation, the Common Customs Tariff, and the TARIC. This reference is vague and does not allow the identification of the specific instruments that the reference aims to cover. We are of the view that the phrase "implementing measures and other related measures" does not "identify the specific measures at issue", as required in Article 6.2 of the DSU.

${ }^{370}$ Appellate Body Report, EC - Bananas III, para. 143. See also Appellate Body Report, India Patents (US), para. 88; Appellate Body Report, Korea - Dairy, para. 139; and Appellate Body Report, Dominican Republic - Import and Sale of Cigarettes, para. 121.

${ }^{371}$ Panel Report, para. 7.33.
} 
WT/DS315/AB/R

Page 62

154. In the light of these considerations, we reverse the Panel's finding, in paragraphs 7.33 and 8.1(a)(i) of the Panel Report, that "the specific measure at issue in this dispute ... is the manner of administration ... of the Community Customs Code, the Implementing Regulation, the Common Customs Tariff, the TARIC and related measures in the areas of customs administration specifically identified in the United States' request for establishment of a panel." ${ }^{372}$ We find, instead, that the specific measures at issue identified in the panel request are the Community Customs Code, the Implementing Regulation, the Common Customs Tariff, and the TARIC, as administered collectively.

C. The United States' Claim Challenging the European Communities' System of Customs Administration "As a Whole"

155. We now turn to the question whether the Panel erred in finding that, due to the terms of the panel request, the United States was precluded from challenging the European Communities' system of customs administration as a whole or overall.

156. The Panel made separate findings regarding the scope and the nature of the United States' challenge under Article X:3(a) of the GATT 1994 of the European Communities' system of customs administration. ${ }^{373}$ With respect to the scope of the United States' challenge, the Panel found that, due to the wording and content of the panel request, the United States was precluded from challenging the European Communities' system of customs administration as a whole or overall, and that its terms of reference regarding the scope of the United States' claim under Article X:3(a) were restricted to the specific areas of customs administration referred to in the panel request. ${ }^{374}$ Although the Panel acknowledged the permissibility of challenging "a responding Member's system as a whole or overall ${ }^{375}$, it considered that, in this case, the reference in the panel request to a number of areas of customs administration indicated that the United States' claim under Article X:3(a) extends to some, but not all, areas of customs administration. ${ }^{376}$ In reaching its conclusion, the Panel noted that the areas of customs administration listed in the panel request did not cover the totality of the European Communities' system of customs administration. ${ }^{377}$

\footnotetext{
${ }^{372}$ Panel Report, para. 8.1(a)(i).

${ }^{373}$ Ibid., paras. 7.50 and 7.63 .

${ }^{374}$ Ibid., para. 7.46.

${ }^{375}$ Ibid., para. 7.44.

${ }^{376}$ Ibid., para. 7.47 .

${ }^{377}$ Ibid., para. 7.48. In this respect, the Panel noted that areas of customs administration, such as transit procedures, customs debt, inward processing, outward processing, exportation, and re-exportation, were absent
} from that list. 
157. With respect to the nature of the United States' challenge, the Panel concluded that, on the basis of the language and content of the panel request, the United States was precluded from making an "as such" challenge to the design and structure of the European Communities' system of customs administration as a whole, as well as in the areas of customs administration specifically identified in the panel request. ${ }^{378}$ For the Panel, "there is nothing in the text of the United States' request for establishment of a panel that could be construed as clearly suggesting that the United States' challenge under Article X:3(a) of the GATT 1994 relates to the design and structure of the [European Communities'] system of customs administration. ${ }^{379}$ The Panel further held that, in the panel request, the United States was concerned with the manner of administration by member State customs authorities, rather than with the design and structure of the customs administration system at the European Communities level "as such" ${ }^{380}$; in addition, such a challenge "is not obviously linked to the essence of the obligation contained in Article X:3(a) of the GATT 1994—namely, the obligation to administer in a uniform manner". ${ }^{381}$ Finally, the Panel observed that the panel request makes no explicit reference to the terms "as such" or "per se". ${ }^{382}$

158. On appeal, the United States contends that the Panel erred by construing the panel request to exclude a claim that the European Communities' system of customs administration as a whole results in non-uniform administration of European Communities customs law, in breach of Article X:3(a) of the GATT $1994 .{ }^{383}$ For the United States, the Panel erred in considering that, in order to challenge the European Communities' system of customs administration as a whole, the United States would have had to list separately each and every area of customs administration. ${ }^{384}$ The United States maintains that the panel request made it clear that its claim related to the European Communities' system of customs administration as a whole, because it identified the measures that constitute the main instruments of European Communities customs legislation and addressed the manner of administration of these instruments collectively. ${ }^{385}$ For the United States, the crux of its claim was that "the [European Communities] administers its customs law through 25 separate, independent customs authorities and does not provide any institution or mechanism to reconcile divergences automatically and as a matter of right when they occur." ${ }^{386}$ In the United States' view, the Panel failed

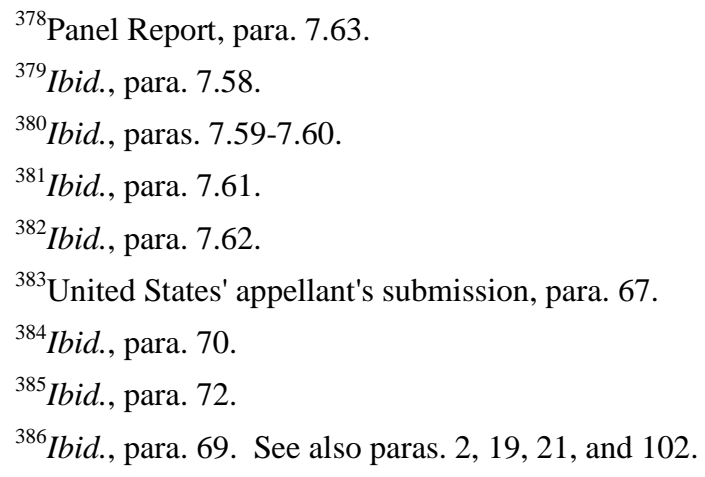


WT/DS315/AB/R

Page 64

to consider the panel request "as a whole". ${ }^{387}$ The United States emphasizes that the measures at issue were discussed collectively throughout the panel request, and that this is "precisely what one would expect in a panel request challenging a system of customs administration as a whole". ${ }^{388}$

159. According to the United States, it clearly articulated a challenge of the European Communities' system of customs administration as a whole, as evident from the very first sentence of the panel request. ${ }^{389}$ It would be "illogical to assume that [the] use of the word 'manner' in a claim involving Article X:3(a) of the GATT 1994 necessarily suggests that the claim does not relate to a Member's system of customs administration as a whole." ${ }^{\text {"390 }}$ Furthermore, the United States is of the view that, because "the defining characteristic of the design and structure" of the European Communities' system of customs administration is the absence of procedures and institutions at the European Communities level, a challenge to the design and structure of this system necessarily must address administration undertaken by member State customs authorities. ${ }^{391}$

160. The United States also points out that the absence of an explicit reference to the terms "as such" or "per se" in the panel request does not preclude a claim with respect to the European Communities' system of customs administration as a whole: what is important, is that the responding party be aware of the claim against it so that its ability to defend itself is not prejudiced. ${ }^{392}$ The United States maintains that the European Communities was aware that the United States had made a claim with respect to the European Communities' system of customs administration, as can be seen from the statements of the European Communities at meetings of the DSB $^{393}$ and the European Communities' submissions and statements during the Panel proceedings. ${ }^{394}$

161. According to the European Communities, the Appellate Body should uphold the Panel's finding that the United States' claims regarding the European Communities' system of customs administration "as a whole" and "as such" are outside its terms of reference. The European Communities considers the "as a whole" claim to be outside the Panel's terms of reference, because the measure at issue set out in the panel request is "only the [European Communities'] manner of administration in the areas of customs law specifically identified in [the] Panel Request". ${ }^{395}$ The

\footnotetext{
${ }^{387}$ United States' appellant's submission, para. 73.

${ }^{388}$ Ibid., para. 74.

${ }^{389}$ Ibid., para. 82.

${ }^{390}$ Ibid., para. 77.

${ }^{391}$ Ibid., para. 78.

${ }^{392}$ Ibid., para. 83.

${ }^{393}$ Ibid., paras. 86-87.

${ }^{394}$ Ibid., paras. 88-91.

${ }^{395}$ European Communities' appellee's submission, para. 113.
} 
European Communities also maintains that "[i]t is incorrect to suggest that the [European Communities'] system of customs administration could be assessed 'as a whole', independently of the specific needs and requirements of the sector or area in question, and the tools and mechanisms existing in such area." ${ }^{396}$

162. The European Communities argues that the panel request did not indicate that the United States intended to challenge the European Communities' system of customs administration "as such". For the European Communities, the panel request identified, as the measure at issue, only the "manner of administration". In the European Communities' view, the term "manner of administration" is "diametrically opposed to [what] one could have expected to be used in the case of a challenge against a measure 'as such'." 397 The European Communities adds that its system of customs administration is broader than the instruments listed in the first paragraph of the panel request, because it includes other instruments such as the Treaty Establishing the European Communities (the "EC Treaty") and more specific instruments existing in the field of customs cooperation or budgetary and financial control. ${ }^{398}$

163. With respect to the United States' reliance on a number of statements made by the parties during or before the Panel proceedings ${ }^{399}$, the European Communities submits that "the compliance of a [p]anel request with Article 6.2 [of the] DSU must be assessed primarily on the face of the [p]anel request." ${ }^{400}$ The European Communities also asserts that at no point did it recognize or acknowledge that the European Communities' system of customs administration "as such" was the measure at issue. $^{401}$

164. The United States' appeal raises three questions that we address in turn. First, is a Member allowed to challenge within the WTO dispute settlement proceedings another Member's legal system as a whole or overall? Secondly, assuming that such a challenge could be made, did the Panel err in finding that, due to the wording and content of the panel request, the United States was "precluded from challenging the [European Communities'] system of customs administration as a whole or overall"? ${ }^{402}$ Thirdly, did the Panel err in considering that the United States' contention on the "design and structure" of the European Communities' system of customs administration as a whole was outside its terms of reference?

\footnotetext{
${ }^{396}$ European Communities' appellee's submission, para. 117.

${ }^{397}$ Ibid., para. 125.

${ }^{398}$ Ibid., para. 128.

${ }^{399}$ United States' appellant's submission, paras. 84-98.

${ }^{400}$ European Communities' appellee's submission, para. 131.

${ }^{401}$ Ibid., para. 133.

${ }^{402}$ Panel Report, para. 7.46.
} 
WT/DS315/AB/R

Page 66

\section{1. $\quad$ Challenging a Legal System "As a Whole" or "Overall"}

165. The United States contends that its claim relates to the European Communities' system of customs administration "as a whole or overall". As a preliminary observation, we do not think that, by challenging the European Communities' system of customs administration as a whole, the United States made an "as such" claim. ${ }^{403}$ Indeed, before the Panel, the United States made it clear that it was "not challenging the substance of the measures mentioned in its request for establishment of a panel". ${ }^{404}$ This was confirmed by the United States in response to questioning at the oral hearing. Also at the oral hearing, the United States explained that, in this dispute, the claim made by the United States under Article X:3(a) is not readily classifiable in the categories of "as such" and "as applied" claims, that it would be inaccurate to characterize its claim as an "as such" claim, and that it did not wish to add a further category of claims.

166. We agree with the Panel that "there is nothing in the DSU nor in the other WTO agreements that would prevent a complaining Member from challenging a responding Member's system as a whole or overall." ${ }^{405}$ We also agree with the Panel that a challenge that a system "as a whole or overall" is WTO-inconsistent must be presented in a manner that meets the two distinct requirements in Article 6.2 of the DSU. ${ }^{406}$ A panel request must identify, with a sufficient degree of specificity, the measures that constitute or underlie the legal system challenged "as a whole or overall", and must also provide the legal basis of the complaint (or the claims) so as to present the problem clearly. ${ }^{407} \mathrm{We}$ already concluded in the previous section that, in the panel request, the United States has identified the measures at issue in this dispute in a manner that satisfies the specificity requirement in Article 6.2 of the DSU. We also disagreed with the Panel's view that, in the context of this dispute, the specificity requirement in Article 6.2 of the DSU "additionally requires the identification of ... customs areas". ${ }^{408}$ We also recognize, as the Panel did, that, in this case, the legal instruments referred to by the United States in the panel request, "cumulatively, contain" a vast number of provisions that relate to a variety of customs areas and that "entail administration in ... diverse ways". ${ }^{409}$ However, the essence of the United States' claim was not the administration or application

\footnotetext{
${ }^{403}$ See also our explanation infra, para. 174.
}

${ }^{404}$ Panel Report, para. 7.5. (emphasis added) We recall that an "as such" claim challenges an "act[] setting forth rules or norms that are intended to have general and prospective application". (Appellate Body Report, US - Corrosion-Resistant Steel Sunset Review, para. 82. See also Appellate Body Report, US - Oil Country Tubular Goods Sunset Reviews, para. 172) In other words, an "as such" claim in WTO parlance challenges the substantive content of the measure at issue regardless its application in individual instances.

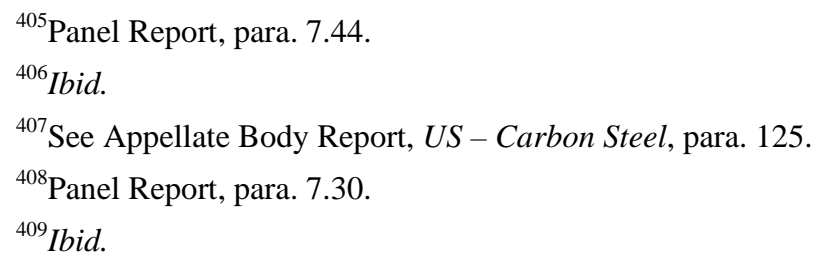


of individual provisions of these legal instruments, but the absence of any mechanism or procedure at the European Communities level to reconcile divergences in the administration of these instruments by the member States of the European Communities. ${ }^{410}$ Therefore, we do not think that the due process rights of the European Communities were infringed merely because the claim of the United States related to the manner of administration of the European Communities customs law as a whole or overall.

167. Under Article 6.2 of the DSU, a panel request must also provide a brief summary of the legal basis of the complaint sufficient to present the problem clearly. In other words, a panel request must summarize the claim made in a manner that will "serve the due process objective of notifying the parties and third parties to a dispute of the nature of the complainant's case". 411 As the Appellate Body stated in Thailand - H-Beams, the due process objective is "fundamental to ensuring a fair and orderly conduct of dispute settlement proceedings". ${ }^{412}$ In Korea - Dairy, the Appellate Body emphasized that, although Article 6.2 of the DSU demands only a summary of the legal basis of the complaint (or the claim), this summary must be "sufficient to present the problem clearly", and it is not enough only to "summarily identify" the legal basis of the complaint. ${ }^{413}$ Compliance with the requirement of summarizing the claim in the panel request in a manner that "presents the problem clearly" ${ }^{\prime 14}$ must be demonstrated, in principle, on the face of the panel request. ${ }^{415}$ With these general considerations in mind, we address the question of whether the panel request included a challenge to the European Communities' system of customs administration as a whole or overall under Article X:3(a) of the GATT 1994.

2. Whether the Panel Request Included a Challenge to the European Communities' System of Customs Administration "As a Whole" or "Overall"

168. The United States' appeal requires us to examine the wording and content of the panel request. Determining the scope of the claims that are set out in a panel request requires that the panel request be construed as a whole. ${ }^{416}$ We will be able to conclude that the panel request included a challenge to the European Communities' system of customs administration as a whole or overall only

${ }^{410}$ United States' appellant's submission, paras. 2, 19, 21, 69, and 102.

${ }^{411}$ Appellate Body Report, US - Carbon Steel, para. 126. (original emphasis) See also Appellate Body Report, Brazil - Desiccated Coconut, at 186; and Appellate Body Report, EC - Bananas III, para. 142.

${ }^{412}$ Appellate Body Report, Thailand - H-Beams, para. 88.

${ }^{413}$ Appellate Body Report, Korea - Dairy, para. 120.

${ }^{414}$ Article 6.2 of the DSU.

${ }^{415}$ Appellate Body Report, US - Carbon Steel, para. 127.

${ }^{416}$ See Appellate Body Report, US - FSC (Article 21.5 - EC II), paras. 66-68; and Appellate Body Report, US - Carbon Steel, para. 127. 
WT/DS315/AB/R

Page 68

if we are convinced that the panel request, read as a whole, states this claim in a way that is "sufficient to present the problem clearly".

169. As we concluded earlier, the specific measures at issue identified in the panel request are the Community Customs Code, the Implementing Regulation, the Common Customs Tariff, and the TARIC, as administered collectively. ${ }^{417}$ It is not in dispute that these are major instruments of European Communities customs legislation. Together, they delineate the legal architecture of the European Communities' customs regime. In other words, the administration of these legal instruments covers, if not the entirety, almost the whole of the European Communities' system of customs administration. ${ }^{418}$

170. The wording and content of the panel request shows that the United States' challenge under Article X:3(a) of the GATT 1994 concerns the manner of administration of these measures collectively or as a whole. The panel request begins by stating: "the manner in which the European Communities ... administers its laws, regulations, decisions and rulings of the kind described in Article X:1 of [the GATT 1994] is not uniform." The second sentence of the first paragraph begins, "[f]or purposes of this request, the laws, regulations, decisions and ruling (collectively, 'measures')".

171. In turn, the second paragraph of the panel request states that "[a]dministration of these measures in the European Communities is carried out by the national customs authorities of [European Communities] member States" and that "[s]uch administration takes numerous different forms." In this paragraph, it is further stated that "the myriad forms of administration of these measures include, but are not limited to, laws, regulations, handbooks, manuals, and administrative practices of customs authorities of member States of the European Communities." The third paragraph of the panel request states that the "[l]ack of uniform, impartial and reasonable administration of the above-identified measures is manifest in differences among member States in a number of areas." In our view, these statements in the panel request present with sufficient clarity the complaint of the United States, namely, that the instruments identified in the first paragraph of the panel request are administered collectively, or as a whole, in breach of Article X:3(a). The fact that the panel request does not refer, explicitly or implicitly, to the manner of administration of particular

\footnotetext{
${ }^{417}$ See supra, para. 154.

${ }^{418}$ In this respect, we note the European Communities' contention that the European Communities' system of customs administration is somewhat broader than the administration of the four legal instruments to which the first paragraph of the panel request refers, and that the European Communities' system of customs administration rests as well on other measures such as "the EC Treaty itself" and "more specific instruments existing in the field of customs cooperation or budgetary and financial control". (European Communities' appellee's submission, para. 128)
} 
provisions or instruments supports the view that the claim of the United States relates to the manner in which these instruments are administered collectively or as a whole.

172. In its appellant's submission as well as in response to questioning at the oral hearing, the United States has emphasized that the crux of its claim under Article X:3(a) is that "the existence of a system of customs administration in which 25 separate, independent authorities exercise judgment in interpreting and applying [European Communities] customs law, without any procedures or institutions to ensure against divergences or to reconcile them promptly and as a matter of right when they occur, necessarily constitutes a lack of uniform administration, in breach of Article X:3(a)."419 Before the Panel, the United States also stressed the absence of such a reconciliation mechanism at the European Communities level. We observe that the panel request does not state in the same way this central element of the challenge the United States makes of the European Communities' system of customs administration. We think that the panel request could have been drafted with more precision. Had the United States explicitly stated in the panel request that the heart of the problem is the absence of any procedures or institutions or mechanisms to ensure against divergences or to reconcile them promptly and as a matter of right when they occur, there would have been little doubt as to whether the panel request set out a claim under Article X:3(a) against the European Communities' system of customs administration as a whole. Nevertheless, as we indicated above, by highlighting the nature and extent of the differences that exist in the administration of European Communities customs law by the member States, the panel request presents with sufficient clarity, as required by Article 6.2 of the DSU, that the claim made under Article X:3(a) concerned the European Communities' system of customs administration as a whole or overall.

\section{The Panel's Finding with respect to the "Design and Structure" of the European Communities' System of Customs Administration}

173. The Panel concluded that, on the basis of the language and content of the panel request, the United States was precluded from making an "as such" challenge with respect to the "design and structure" of the European Communities' system of customs administration. ${ }^{420}$ This finding is challenged on appeal by the United States.

174. As we concluded earlier, the specific measures at issue are the four legal instruments identified in the first paragraph of the panel request, as administered collectively. The United States' claim is that the European Communities' system of customs administration as a whole results in nonuniform administration of European Communities customs law, in breach of Article X:3(a) of the

\footnotetext{
${ }^{419}$ United States' appellant's submission, para. 102. See also paras. 2, 19, 21, and 69.

${ }^{420}$ Panel Report, para. 7.63.
} 
WT/DS315/AB/R

Page 70

GATT 1994. As we noted earlier, the claim of the United States in this dispute is not an "as such" claim, in the sense that it does not challenge the substantive content of the measures at issue. ${ }^{421}$

175. Before the Panel, and again in this appellate proceeding, the United States argues that the "design and structure" of the European Communities' system of customs administration necessarily result in non-uniform administration, because customs laws are administered by "25 separate, independent authorities ... without any procedures or institutions to ensure against divergences or to reconcile them promptly and as a matter of right when they occur." ${ }^{422}$ By referring to the "design and structure" of the European Communities' system of customs administration, the United States sought to demonstrate how and why the instruments identified in the first paragraph of the panel request, as a whole, are administered in a manner leading to a lack of uniformity in their administration. ${ }^{423}$ Thus, the United States' contention on the "design and structure" of the European Communities' system of customs administration was made as an argument to substantiate its "as a whole" challenge set out in the panel request. We therefore disagree with the Panel's characterization of the United States' contention on the "design and structure" of the European Communities' system of customs administration as a claim in itself. We noted earlier that the "as a whole" challenge of the United States is set out in the panel request consistently and according to the specificity requirements contained in Article 6.2 of the DSU. We therefore see no reason why the Panel was precluded from

\footnotetext{
${ }^{421}$ On the distinction between challenging a set of measures or a legal system as a whole and an "as such" claim, see also supra, para. 165 and footnote 404 thereto.

${ }^{422}$ United States' response to Question 126 posed by the Panel concerning the European Communities' system of customs administration, Panel Report, p. B-4. We note that, in its response to Question 126, the United States stated that it understands the "design and structure" to mean the following:

- Customs law in the [European Communities] is prescribed by [European Communities] institutions: the Council and the Commission.

- $\quad$ [European Communities] customs law is administered by 25 different authorities, each responsible for a different part of the territory of the [European Communities].

- The [European Communities] has in place certain procedures and institutions which it contends secure uniform administration among the 25 different authorities. These include a general duty of cooperation among member States, guidelines on various matters (e.g., the conduct of customs audits), discretionary mechanisms (e.g., referral of questions to the Customs Code Committee), and the opportunity for traders to appeal customs administrative action to member State courts, with the possibility of such courts eventually referring questions of [European Communities] law to the ECJ.
}

The United States further noted: "[W]ithout any mechanism or other means even ostensibly present to ensure that the different authorities acted uniformly".

${ }^{423}$ We note that, in response to questioning by the Panel, the United States stated that "the support for the [United States'] claim under Article X:3(a) includes evidence of both the design and structure of the [European Communities'] system of customs administration and specific instances of non-uniform administration." (United States' response to Question 173 posed by the Panel, Panel Report, p. B-29 (original emphasis)) 
considering the United States' arguments on the "design and structure" of the European Communities' system of customs administration.

176. In the light of these considerations, we reverse the Panel's finding, in paragraphs 7.50, 7.64, and 8.1(a)(iii) of the Panel Report, that, due to the wording and content of the panel request, the United States was precluded from challenging the European Communities' system of customs administration as a whole or overall. We also reverse the Panel's finding, in paragraphs 7.63, 7.64, and 8.1(a)(iii) of the Panel Report, that the Panel was precluded from considering the United States' argument that the "design and structure" of the European Communities' system of customs administration necessarily result in a violation of Article X:3(a) of the GATT 1994.

\section{Temporal Limitations of the Panel's Terms of Reference}

177. The European Communities requests the Appellate Body to review whether the Panel erred in its interpretation of the temporal scope and limitations of its terms of reference in respect of "steps and acts of administration that pre-date or post-date the establishment of a panel". ${ }^{424}$ The European Communities' other appeal focuses on the Panel's reasoning on the temporal scope of its terms of reference as set out in paragraphs 7.36 and 7.37 of the Panel Report.

178. The European Communities argues that the Panel took an excessively wide approach in interpreting the temporal limitations on its terms of reference. ${ }^{425}$ For the European Communities, a panel may, in principle, consider only measures that are in existence at the time of its establishment ${ }^{426}$ and, therefore, the Panel erred in considering that it had "a general competence to also consider measures which 'pre-date' or 'post-date' its establishment". ${ }^{427}$ The European Communities also contends that the manner of administration "cannot be regarded as a 'continuum' without [a] clear start or end point" ${ }^{428}$, contrary to what the Panel suggests. ${ }^{429}$ According to the European Communities, the Panel's approach would produce awkward results: it would imply that "violations which occurred far in the past and which no longer have any current effect could be claimed to be continuing because 'administration has no end point'." ${ }^{430}$ Similarly, "violations which had not yet occurred at the time the

\footnotetext{
${ }^{424}$ Panel Report, para. 7.37.

${ }^{425}$ European Communities' other appellant's submission, para. 40.

${ }^{426}$ Ibid., para. 46.

${ }^{427}$ Ibid., para. 47.

${ }^{428}$ Ibid., para. 63.

${ }^{429}$ Panel Report, para. 7.37.

${ }^{430}$ European Communities' other appellant's submission, para. 65.
} 
WT/DS315/AB/R

Page 72

Panel was established might be regarded as indicative of violations pre-dating the Panel's establishment because administration 'has no starting point'." ${ }^{431}$

179. The European Communities considers that, on the basis of the panel request, it was entitled to assume that the complainant's case related to measures in existence at the time of the Panel's establishment. By defining "administration" under Article X:3(a) of the GATT 1994 as "a phenomenon without any boundaries in time", the Panel violated the due process rights of the defendant protected by Article 6.2 of the DSU, because preparation of the defence for past instances of administration is "unduly difficult", and the inclusion of future instances of administration in the measure makes the subject matter of the case a "moving target". ${ }^{432}$

180. The European Communities also argues that the Panel's reasoning would make compliance almost impossible. If administration has no clear starting or ending point, it would be difficult for a WTO Member found to be in violation of Article X:3(a) to establish that it has altered its manner of administration so as to achieve compliance with Article X:3(a). ${ }^{43}$ The European Communities submits that "the Panel's approach to the temporal limitations to its terms of reference is incompatible with Article[s] 7.1 and 6.2 [of the] DSU"434 and therefore requests the Appellate Body to "reverse the Panel's findings in paragraphs 7.36 and 7.37". ${ }^{435}$

181. The United States is of the view that the Panel did not err in its approach to the temporal scope of its terms of reference. ${ }^{436}$ The United States observes that the legal instruments identified in the panel request were in existence on the date when the Panel was established. ${ }^{437}$ According to the United States, the European Communities' argument "confuses administration of [European Communities] customs law in existence when the Panel was established with individual acts of administration that occurred prior to establishment and with evidence that came to light during the panel proceeding that confirm the existence of non-uniform administration at the time of panel establishment." ${ }^{438}$ For the United States, the Panel correctly explained that "it would take account of individual instances of administration pre-dating and post-dating panel establishment not to determine

\footnotetext{
${ }^{431}$ European Communities' other appellant's submission, para. 65.

${ }^{432}$ Ibid., para. 66.

${ }^{433}$ Ibid., para. 68.

${ }^{434}$ Ibid., para. 69.

${ }^{435}$ Ibid., para. 70.

${ }^{436}$ United States' appellee's submission, para. 51.

${ }^{437}$ Ibid., para. 17.

${ }^{438}$ Ibid., para. 15. (original emphasis)
} 
whether each established a WTO-inconsistency in its own right, but as a means of elucidating the manner of administration that was in existence at the time of panel establishment."439

182. The United States is also of the view that the European Communities misreads the distinction the Panel made between administration as an ongoing phenomenon and individual instances of administration. $^{440}$ For the United States, although the European Communities has referred to the principle that a panel may consider only measures in existence at the time of panel establishment, it made "no distinction between acts of administration themselves being considered as potential breaches of Article X:3(a) and acts of administration being considered as evidence of an ongoing course of administration that potentially is a breach of Article X:3(a)". ${ }^{441}$ The United States underscores that nothing in the text of Article X:3(a) or its context suggests that a breach of that provision "is demonstrated only when individual acts of administration in existence on the date a panel is established diverge". ${ }^{442}$

183. With respect to the European Communities' argument concerning events that post-dated panel establishment, the United States maintains that, contrary to the European Communities' assertion, the Panel's references to evidence post-dating panel establishment do not show the Panel overstepped its terms of reference. According to the United States, these references "show the Panel properly [took] account of evidence relevant to understanding the manner of administration of [European Communities] customs law existing at the time of panel establishment." ${ }^{443}$

184. We begin our analysis by recalling the Appellate Body's statement in EC-Chicken Cuts:

The term "specific measures at issue" in Article 6.2 suggests that, as a general rule, the measures included in a panel's terms of reference must be measures that are in existence at the time of the establishment of the panel. ${ }^{444}$ (footnote omitted)

This general rule, however, is qualified by at least two exceptions. First, in Chile - Price Band System, the Appellate Body held that a panel has the authority to examine a legal instrument enacted after the establishment of the panel that amends a measure identified in the panel request, provided that the amendment does not change the essence of the identified measure. ${ }^{445}$ Secondly, in US -

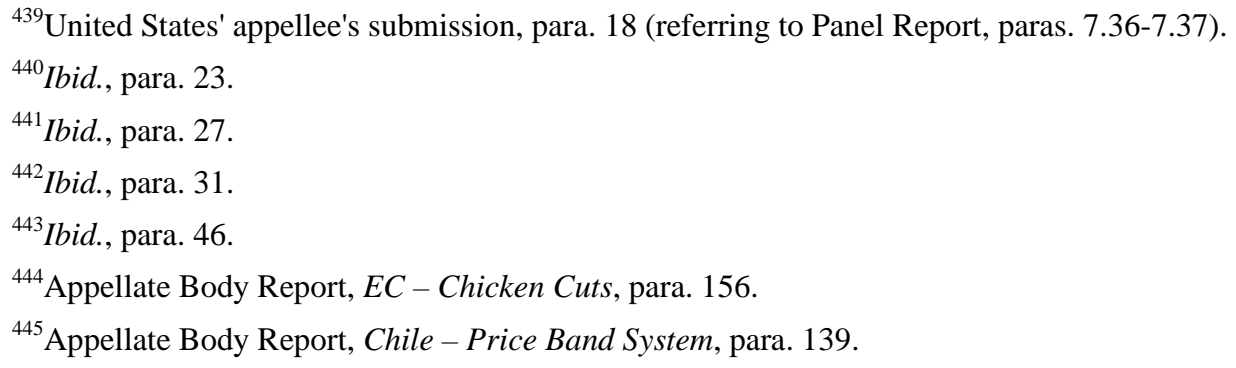


WT/DS315/AB/R

Page 74

Upland Cotton, the Appellate Body held that panels are allowed to examine a measure "whose legislative basis has expired, but whose effects are alleged to be impairing the benefits accruing to the requesting Member under a covered agreement" at the time of the establishment of the panel. ${ }^{446}$ The summary presented by the Panel in paragraph 7.36 of the Panel Report is in line with what the Appellate Body said in EC - Chicken Cuts, Chile - Price Band System, and US - Upland Cotton. ${ }^{447}$ Therefore, we see no error in the Panel's legal interpretation contained in paragraph 7.36 of the Panel Report.

185. Turning to paragraph 7.37 of the Panel Report, we note that the Panel sought to apply in the specific context of this dispute the legal interpretation it had set out in paragraph 7.36 of its Report. The Panel recalled first its view that, in this case, the specific measure at issue "comprises the manner of administration of the Community Customs Code, the Implementing Regulation, the Common Customs Tariff, the TARIC and related measures." ${ }^{448}$ As the Panel identified the measure at issue as the manner of administration, it went on to discuss the temporal scope of the manner of administration for purposes of defining its terms of reference. In particular, the Panel said that "the manner of administration in a particular case may not have a clear starting point or end point", and that "administration may comprise a continuum of steps and acts, some of which may pre-date or post-date the step or act of administration that is considered by a panel at the time of establishment of that panel." ${ }^{449}$ On this basis, the Panel concluded that "the steps and acts of administration that predate or post-date the establishment of a panel may be relevant to determining whether or not a violation of Article X:3(a) of the GATT 1994 exists at the time of establishment."

186. We agree with the conclusion of the Panel that "the steps and acts of administration that predate or post-date the establishment of a panel may be relevant to determining whether or not a violation of Article X:3(a) of the GATT 1994 exists at the time of establishment."450 We are, however, of the view that the reasoning that led the Panel to this conclusion is incorrect.

${ }^{446}$ Appellate Body Report, US - Upland Cotton, para. 263.

${ }^{447}$ See Appellate Body Report, Chile - Price Band System, para. 139; Appellate Body Report, EC Chicken Cuts, para. 156; and Appellate Body Report, US - Upland Cotton, para. 263.

${ }^{448}$ (original emphasis)

${ }^{449}$ (footnote omitted)

${ }^{450}$ Panel Report, para. 7.37. 
187. In our opinion, the Panel's reasoning is incorrect to the extent that the Panel assumed that the measure at issue is the manner of administration. ${ }^{451}$ As we concluded earlier, the measure at issue in this dispute is not the manner of administration but, rather, the legal instruments identified in the first paragraph of the panel request, as administered collectively or as a whole. In the light of the principles set out by the Panel in paragraph 7.36 of the Panel Report, the Panel's review should therefore have focused on these legal instruments as they existed and were administered at the time of establishment of the Panel.

188. In order to determine whether the measures at issue have been administered at the time of the Panel's establishment in a manner that is inconsistent with Article X:3(a) of the GATT 1994, the Panel was, however, entitled to rely on evidence of acts of administration. Thus, it is important to distinguish between, on the one hand, the measures at issue and, on the other hand, acts of administration that have been presented as evidence to substantiate the claim that the measures at issue are administered in a manner inconsistent with Article X:3(a) of the GATT 1994. The Panel failed to make the distinction between measures and pieces of evidence. While there are temporal limitations on the measures that may be within a panel's terms of reference, such limitations do not apply in the same way to evidence. Evidence in support of a claim challenging measures that are within a panel's terms of reference may pre-date or post-date the establishment of the panel. A panel is not precluded from assessing a piece of evidence for the mere reason that it pre-dates or post-dates its establishment. ${ }^{452}$ In this case, the United States was not precluded from presenting evidence relating to acts of administration before and after the date of Panel establishment. A panel enjoys a certain discretion to determine the relevance and probative value of a piece of evidence that pre-dates or post-dates its establishment.

189. We therefore uphold, albeit for different reasons, the Panel's interpretation, in paragraph 7.37 of the Panel Report, that "the steps and acts of administration that pre-date or post-date the establishment of a panel may be relevant to determining whether or not a violation of Article X:3(a) of the GATT 1994 exists at the time of [panel] establishment."

${ }^{451}$ As we explained above, we disagree with the Panel's interpretations of Article 6.2 of the DSU and its reading of the panel request that led the Panel to this assumption.

${ }^{452}$ However, we recall that, in US - Cotton Yarn, the Appellate Body stated (when reviewing a textile safeguards determination) that a Member cannot be expected to examine "evidence that did not exist and that, therefore, could not possibly have been taken into account when the Member made its determination. ... Consequently, a panel must not consider evidence which did not exist at that point in time." (Appellate Body Report, US - Cotton Yarn, paras. 77 and 78 (original emphasis; footnote omitted)) We also note the Appellate Body's statement in EC - Sardines that "[t]he interim review stage is not an appropriate time to introduce new evidence." (Appellate Body Report, EC - Sardines, para. 301) 
WT/DS315/AB/R

Page 76

\section{Claims regarding Article X:3(a) of the GATT 1994}

A. Administration of European Communities Customs Law through Penalty Provisions and Audit Procedures of Member States

1. Whether the Substantive Content of a Legal Instrument May Be Challenged under Article X:3(a) of the GATT 1994

190. We now turn to the question whether the Panel erred in finding that the term "administer" in Article X:3(a) of the GATT 1994 relates to the application of laws and regulations, but not to laws and regulations themselves, and whether, consequently, the Panel erred in finding that divergent penalty provisions and audit procedures found in member States of the European Communities are not inconsistent with Article X:3(a) of the GATT 1994. We first address the Panel's interpretation of the term "administer". Subsequently, we address the question of differences in penalty provisions and audit procedures among the member States.

191. The Panel found that the text of Article X:3(a) does not contemplate the possibility that laws and regulations can simultaneously qualify as laws, regulations, judicial decisions, and administrative rulings of the kind described in Article X:1 of the GATT 1994 and as acts of administration within the meaning of Article X:3(a). The Panel concluded:

[T]he term "administer" in Article X:3(a) of the GATT 1994 relates to the application of laws and regulations, including administrative processes and their results but not to laws and regulations as such. ${ }^{453}$

192. The Panel arrived at this interpretation after its analysis of the ordinary meaning of the term "administer":

[T]here would appear to be nothing in the ordinary meaning of the term "administer" that would suggest that it covers laws and regulations as such. On the contrary, the relevant dictionary definitions indicate that the term "administer" refers to positive action or steps taken to put into effect measures such as laws and regulations, but not the laws and regulations themselves, which merely exist without effect until they are actually applied in practice. ${ }^{454}$ (original emphasis)

\footnotetext{
${ }^{453}$ Panel Report, para. 7.119.

${ }^{454}$ Ibid., para. 7.106.
} 
193. The Panel found that this understanding of Article X:3(a) was confirmed by the context of the provision. In the Panel's view, Article X of the GATT 1994 contains a "due process theme", which suggests that the aim of Article X:3(a) is to ensure that traders are treated fairly and consistently when seeking to import from or export to a particular WTO Member. In this respect the Panel concluded:

[T] to the application of laws in particular cases and, particularly, to administrative processes and their results, since the application of the obligation of uniformity (and, for that matter, the obligation of reasonableness and impartiality) to such processes and their result pursuant to Article X:3(a) of the GATT 1994, helps to ensure that traders are treated fairly and consistently. ... It is not clear that it should be inferred from this objective that Article X:3(a) of the GATT 1994 requires laws and regulations themselves to also be uniform, reasonable and impartial. ${ }^{455}$ (original emphasis)

194. On appeal, the United States contends that the Panel erred in its interpretation of the term "administer". According to the United States, penalty provisions and audit procedures of the member States of the European Communities are themselves acts of administration in the sense of Article X:3(a) and, therefore, divergences in these provisions and procedures from member State to member State, by themselves, constitute non-uniform administration of customs laws in breach of Article X:3(a). ${ }^{456}$

195. The European Communities submits that the Panel was correct to distinguish between the laws to be administered and the administration of those laws, and disagrees with the United States that laws themselves can constitute administration within the meaning of Article X:3(a). The European Communities maintain that it would be "incompatible with the internal logic, wording, and purpose of Article X [of the] GATT" to assume that a law or regulation of general application could be "executed" or "put into effect" by another law or regulation of general application. ${ }^{457}$

196. We begin our analysis by recalling the text of Article X:3(a) of the GATT 1994:

Each Member shall administer in a uniform, impartial and reasonable manner all its laws, regulations, decisions and rulings of the kind described in paragraph 1 of this Article.

\footnotetext{
${ }^{455}$ Panel Report, para. 7.108.

${ }^{456}$ United States' appellant's submission, para. 110.

${ }^{457}$ European Communities' appellee's submission, paras. 209-210.
} 
WT/DS315/AB/R

Page 78

197. With respect to the scope of Article X:3(a), the Appellate Body stated in EC-Bananas III:

The text of Article X:3(a) clearly indicates that the requirements of "uniformity, impartiality and reasonableness" do not apply to the laws, regulations, decisions and rulings themselves, but rather to the administration of those laws, regulations, decisions and rulings. The context of Article X:3(a) within Article X, which is entitled "Publication and Administration of Trade Regulations", and a reading of the other paragraphs of Article $\mathrm{X}$, make it clear that Article $\mathrm{X}$ applies to the administration of laws, regulations, decisions and rulings. To the extent that the laws, regulations, decisions and rulings themselves are discriminatory, they can be examined for their consistency with the relevant provisions of the GATT $1994 .{ }^{458}$ (original emphasis)

198. In EC - Poultry, the Appellate Body made a reference to the above statement and concluded:

[T]o the extent that Brazil's appeal relates to the substantive content of the [European Communities'] rules themselves and not to their publication or administration, that appeal falls outside the scope of Article X of the GATT 1994. The WTO-consistency of such substantive content must be determined by reference to provisions of the covered agreements other than Article X of the GATT $1994 .{ }^{459}$ (original emphasis)

199. Thus, in EC-Bananas III and EC-Poultry, the Appellate Body distinguished between, on the one hand, the laws, regulations, judicial decisions, and administrative rulings of general application set out in Article X:1 of the GATT 1994 and, on the other hand, the administration of these legal instruments. The Appellate Body reasoned that, as Article X:3(a) establishes disciplines on the administration of the legal instruments of the kind described in Article $\mathrm{X}: 1$, claims concerning the substantive content of these Article X:1 legal instruments fall outside the scope of Article X:3(a).

200. The statements of the Appellate Body in EC - Bananas III and EC - Poultry do not exclude, however, the possibility of challenging under Article X:3(a) the substantive content of a legal instrument that regulates the administration of a legal instrument of the kind described in Article X:1. Under Article X:3(a), a distinction must be made between the legal instrument being administered and the legal instrument that regulates the application or implementation of that instrument. While the substantive content of the legal instrument being administered is not challengeable under Article X:3(a), we see no reason why a legal instrument that regulates the application or

\footnotetext{
${ }^{458}$ Appellate Body Report, EC - Bananas III, para. 200.

${ }^{459}$ Appellate Body Report, EC - Poultry, para. 115.
} 
implementation of that instrument cannot be examined under Article X:3(a) if it is alleged to lead to a lack of uniform, impartial, or reasonable administration of that legal instrument.

201. This distinction has implications for the type of evidence required to support a claim of a violation of Article X:3(a). If a WTO Member challenges under Article X:3(a) the substantive content of a legal instrument that regulates the administration of a legal instrument of the kind described in Article X:1, it will have to prove that this instrument necessarily leads to a lack of uniform, impartial, or reasonable administration. It is not sufficient for the complainant merely to cite the provisions of that legal instrument. The complainant must discharge the burden of substantiating how and why those provisions necessarily lead to impermissible administration of the legal instrument of the kind described in Article X:1.

\section{Differences in Penalty Provisions and Audit Procedures}

202. We now turn to the question whether divergences in penalty provisions and audit procedures among member States necessarily lead to non-uniform administration in breach of Article X:3(a) of the GATT 1994.

203. First, with respect to penalty provisions, the Panel observed that neither the Community Customs Code nor the Implementing Regulation defines offences at the European Communities level. It further noted the statement by the Court of Justice of the European Communities (the "ECJ") in the case José Teodoro de Andrade v. Director da Alfândega de Leixões that, "[as] regards customs offences, the [ECJ] has pointed out that in the absence of harmonization of the Community legislation in that field, the member States are empowered to choose the penalties which seem appropriate to them. ${ }^{460}$ The Panel then made a reference to its own interpretation of the term "administer" (summarized above) and concluded:

For the purposes of Article X:3(a) of the GATT 1994, the substantive content of penalty laws of the member States used to enforce [European Communities] customs law cannot be viewed as acts of administration with respect to laws, regulations, decisions and rulings covered by Article X:1 of the GATT. Therefore, substantive differences in penalty laws between member States cannot be considered to be in violation of Article X:3(a) of the GATT $1994 .{ }^{461}$

\footnotetext{
${ }^{460}$ Panel Report, para. 7.443 (quoting case C-213/99, José Teodoro de Andrade v. Director da Alfândega de Leixões, [2000] ECR I-11083 (7 December 2000) (Exhibit US-31 submitted by the United States to the Panel), para. 20).

${ }^{461}$ Ibid., para. 7.444 .
} 
WT/DS315/AB/R

Page 80

204. Secondly, with respect to the question whether substantive differences in audit procedures among member States lead to non-uniform administration of the Community Customs Code and the Implementing Regulation in violation of Article X:3(a) of the GATT 1994, the Panel found no such violation in audit procedure requirements of Article 78(2) of the Community Customs Code ${ }^{462}$, based on the following reasoning:

[D]ivergences resulting from the exercise of discretion in the law being administered do not necessarily fall foul of Article X:3(a) of the GATT 1994 provided that the existence and exercise of discretion do not unduly compromise the underlying due process objective of Article X:3(a) of the GATT 1994 and do not render the trading environment insecure and unpredictable without just cause. ${ }^{463}$

205. The United States challenges the Panel's finding that penalty provisions and audit procedures are not themselves acts of administration and, therefore, divergences in those provisions or procedures cannot constitute a lack of uniform administration of European Communities customs law. ${ }^{464}$ With respect to penalty provisions, the United States submits that, if divergences between individual acts of administration (for example, the imposition of different penalties for the same breaches of European Communities customs law) constitute non-uniform administration, then, a fortiori, divergences between the penalty provisions that govern the individual acts of administration carried out by different customs authorities must also constitute non-uniform administration. ${ }^{465}$

206. With respect to audit procedures, the United States submits that the Panel erred in limiting the scope of the United States' claim to the non-uniform administration of Article 78(2) of the Community Customs Code. The United States further submits that, even if the Panel had been correct in limiting its examination to Article 78(2) of the Community Customs Code, the Panel's reasoning is based on an incorrect interpretation and application of the term "administer" contained in

${ }^{462}$ Article 78(2) of the Community Customs Code provides:

The customs authorities may, after releasing the goods and in order to satisfy themselves as to the accuracy of the particulars contained in the declaration, inspect the commercial documents and data relating to the import or export operations in respect of the goods concerned or to subsequent commercial operations involving those goods. Such inspections may be carried out at the premises of the declarant, of any other person directly or indirectly involved in the said operations in a business capacity or of any other person in possession of the said document and data for business purposes. Those authorities may also examine the goods where it is still possible for them to be produced.

${ }^{463}$ Panel Report, para. 7.434.

${ }^{464}$ United States' appellant's submission, para. 109.

${ }^{465}$ Ibid., para. 125. 
Article X:3(a) of the GATT 1994. The United States submits that the error in the Panel's analysis is essentially the same as the error in its analysis of penalty provisions. Therefore, the arguments presented by the United States in that context are equally valid in the context of audit procedures. ${ }^{466}$

207. In reply, the European Communities refers to the binding principles of European Communities law, according to which penalties must be effective, proportionate, and dissuasive ${ }^{467}$, and submits that these principles ensure uniform application of customs laws throughout the European Communities. The European Communities also points out that the United States has not provided concrete evidence concerning the nature and level of sanctions set out in member States' laws for specific violations of customs provisions and thus has not established that, in practice, differences in penalty laws result in differences in the administration of European Communities customs law. ${ }^{468}$

208. With respect to the administration of audit procedures, the European Communities submits that these claims are substantially different from the claims relating to differences in penalty provisions, because audit procedures "are not set out in [m]ember States' law". 469 The European Communities asserts that uniform practice in this respect is ensured by the Community Customs Audit Guide. ${ }^{470}$ The European Communities also notes the discretionary character of Article 78(2) of the Community Customs Code and argues that the mere exercise of discretion in one way or another does not constitute non-uniform administration. ${ }^{471}$

209. In our analysis, we first note the Panel's observation that the existence of differences among penalty provisions for violations of European Communities customs law is not disputed between the parties. ${ }^{472}$ The parties confirmed this understanding at the oral hearing. We also recall the European

${ }^{466}$ United States' appellant's submission, para. 154.

${ }^{467}$ European Communities' appellee's submission, paras. 202 and 222.

${ }^{468}$ Ibid., paras. 221-232.

${ }^{469}$ Ibid., para. 234.

${ }^{470}$ Ibid., para. 237 (referring to the Community Customs Audit Guide, a framework for post-clearance and audit-based controls (Exhibit EC-90 submitted by the European Communities to the Panel)).

${ }^{471}$ Ibid., para. 241.

${ }^{472}$ Panel Report, para. 7.444. 
WT/DS315/AB/R

Page 82

Communities' assertion that, under European Communities customs law, sanctions for the violation of customs laws which member States provide must be effective, proportionate, and dissuasive. ${ }^{473}$

210. We already found that the substantive content of legal instruments that regulate the application or implementation of laws, regulations, decisions, and administrative rulings of the kind described in Article X:1 can be challenged under Article X:3(a). ${ }^{474}$ We therefore consider that the penalty laws of member States, as instruments of implementation of European Communities customs law, can be examined under Article X:3(a). However, the United States must substantiate how and why divergences in penalty laws among member States necessarily lead to non-uniform administration of European Communities customs law.

211. In our view, differences in penalty provisions, in and of themselves, do not necessarily lead to a violation of Article X:3(a). Whether differences would lead to non-uniform administration depends on both the nature of the penalty provisions and the nature of the customs law provisions that they seek to enforce. No evidence was adduced by the United States before the Panel on either the degree of differences in the penalty provisions of the member States or the impact of such differences in the enforcement of the provisions of European Communities customs law.

212. Furthermore, the effects of the differences in penalty provisions would need to be evaluated against the degree of uniformity in administration of European Communities customs law that is envisaged by Article X:3(a). The effects of the differences among member States' laws on uniformity in the administration of European Communities customs law has not been established. Therefore, we do not need to address the question of what degree of uniformity in the administration of laws of the kind described in Article X:1 is required by Article X:3(a). ${ }^{475}$

213. The United States' case rests essentially on the plea that, if divergences in the individual acts of administration can constitute non-uniform administration, then, a fortiori, divergences in the penalty provisions that govern the individual acts of administration carried out by different customs

\footnotetext{
${ }^{473}$ European Communities' appellee's submission, para. 202 (referring to Case C-68/88, Commission/Greece, [1989] ECR 2965, paras. 23-25 (Exhibit EC-38 submitted by the European Communities to the Panel); similarly, Case C-326/88, Hansen, [1990] ECR I-2911, para. 17 (Exhibit EC-39 submitted by the European Communities to the Panel); Case C-36/94, Siesse, [1995] ECR I-3573, para. 20 (Exhibit EC-40 submitted by the European Communities to the Panel); Case C-213/99, Andrade, [2000] ECR I-11083, paras. 19-20 (Exhibit US-31 submitted by the United States to the Panel); as well as to a Council Resolution of 29 June 1995 on the effective uniform application of Community law and on the penalties applicable for breaches of Community law in the internal market, Official Journal of the European Communities, C Series, No. 188, pp. 1-3 (22 July 1995) (Exhibit EC-41 submitted by the European Communities to the Panel)).

${ }^{474}$ Supra, para. 200.

${ }^{475}$ We note that this question is not before us, as neither the United States nor the European Communities has appealed the Panel's findings relating to the interpretation of the term "uniform" in Article X:3(a) of the GATT 1994.
} 
authorities must also constitute non-uniform administration. This argument presupposes that differences between individual acts of administration are a reflection of differences between the penalty provisions. However, in our view, this need not always be the case. The differences may stem as well from the exercise of discretion in the application of the law and the specific circumstances of the case.

214. The United States has not provided concrete examples of the application of penalty provisions in member States that demonstrate non-uniform administration of European Communities customs law. The United States referred only to a single sentence in the European Commission document "An Explanatory Introduction to the modernized Customs Code", which reads:

Specific offences may be considered in one Member State as a serious criminal act possibly leading to imprisonment, whilst in another Member State the same act may only lead to a small-or even no-fine. ${ }^{476}$

Clearly, this single sentence is not sufficient. Thus, the United States has not established that the mere existence of differences in penalty provisions among member States, in and of themselves, has led to non-uniform administration of European Communities customs law.

215. With respect to differences in audit procedures among member States of the European Communities, we note at the outset that Article 78(2) of the Community Customs Code empowers customs authorities to conduct audits following the release of goods for free circulation, but it does not oblige them to do so. ${ }^{477}$ We are also aware that a certain degree of uncertainty as to when and under what conditions an audit will be carried out is in the interest of sound customs administration and must be accepted by traders as part of a normal customs regime. ${ }^{478}$

216. As we indicated in relation to penalty laws, the mere existence of differences in the laws themselves is not sufficient to show a breach of the uniformity requirement in Article X:3(a) with respect to the administration of European Communities customs law. In order to establish its claim, the United States would have had to show that differences in audit procedures necessarily lead to nonuniform administration of European Communities customs law in particular cases. In our view, the United States did not make such a demonstration before the Panel. Different results in the application of a law or provision do not necessarily reflect non-uniform administration of the law itself, but may

${ }^{476}$ United States' appellant's submission, para. 123 (quoting European Commission document Directorate-General for Taxation and Customs Union, TAXUD/447/2004 Rev 2, An Explanatory Introduction to the modernized Customs Code (24 February 2005) (Exhibit US-32 submitted by the United States to the Panel), p. 13).

\footnotetext{
${ }^{477}$ Panel Report, para. 7.429 .

${ }^{478}$ Ibid., para. 7.432 .
} 
WT/DS315/AB/R

Page 84

stem as well from the exercise of discretion in the application of the law or circumstances of the case. The United States did not submit to the Panel any concrete example of the application of audit procedures that led to non-uniform administration of European Communities customs law.

217. In the light of the above, we reverse the Panel's finding, in paragraph 7.119 of the Panel Report, that, without exception, Article X:3(a) of the GATT 1994 always relates to the application of laws and regulations, but not to laws and regulations as such. ${ }^{479}$ In our view, the possibility of challenging under Article X:3(a) the substantive content of a legal instrument that regulates the administration of a legal instrument of the kind described in Article X:1 cannot be excluded. Yet, we consider that the Panel did not err when it found that differences in penalty provisions and audit procedures, themselves, do not establish a breach of the uniformity requirement in Article X:3(a) of the GATT 1994. We therefore uphold the Panel's conclusions, in paragraphs 7.434, 7.444, 8.1(d)(i), and 8.1(d)(ii) of the Panel Report, that substantive differences in penalty laws and audit procedures among the member States of the European Communities alone do not constitute a violation of Article X:3(a) of the GATT 1994.

\section{B. The Administrative Process and the Requirement of Uniformity in Article X:3(a) of the GATT 1994}

218. We now turn to the question whether Article X:3(a) of the GATT 1994 requires uniformity of administrative processes.

219. The Panel found that the term "administer" in Article X:3(a) of the GATT 1994 relates to the application of laws and regulations, including administrative processes and their results. ${ }^{480}$ The Panel reasoned that the ordinary meaning of this term implies that it "covers the application of laws, regulations, decisions and rulings in particular cases" ${ }^{481}$ and that "the application of a law in a particular case encompasses the administrative process entailed in that application, because the administrative process represents the series of steps, actions or events that are taken or occur in pursuance of what is required by the law in question." ${ }^{482}$ The Panel added that "the application of a law in a particular case encompasses the results of administrative processes ... because [they] are the final manifestation of the application of a law in a particular case." ${ }^{483}$

\footnotetext{
${ }^{479}$ Panel Report, para. 7.119.

${ }^{480}$ Ibid., para. 7.113.

${ }^{481}$ Ibid., para. 7.104. (original emphasis)

${ }^{482}$ Ibid., para. 7.105. (original emphasis; footnote omitted)

${ }^{483}$ Ibid. (original emphasis)
} 
220. Moving to contextual interpretation, the Panel noted that "[t]he title as well as the content of the various provisions of Article X of the GATT 1994 indicate that that Article, at least in part, is aimed at ensuring that due process is accorded to traders when they import or export." ${ }^{484}$ For the Panel, "[t]he due process theme underlying Article X of the GATT 1994" ultimately suggests that "the term 'administer' in Article X:3(a) of the GATT 1994 relates to the application of laws in particular cases and, particularly, to administrative processes and their results, since the application of the obligation of uniformity (and, for that matter, the obligations of reasonableness and impartiality) to such processes and their results pursuant to Article X:3(a) of the GATT 1994, helps to ensure that traders are treated fairly and consistently." 485

221. In its other appeal, the European Communities considers that the Panel's reasoning is incorrect because it implies that "the obligation of uniform administration in Article X:3(a) [of the] GATT does not only apply to the outcomes of administration, but also to 'administrative processes'." ${ }^{486}$ For the European Communities, Article X:3(a) does not require that the administrative process "must be fully uniform in all cases and respects". ${ }^{487}$ The European Communities also emphasizes that, "[i]n most administrations, procedures are not fully regulated or harmonised." 488 The European Communities doubts that total uniformity of administrative procedures is required in order to ensure that traders are treated fairly and consistently. ${ }^{489}$ In the view of the European Communities, whether the requirement of uniformity in Article X:3(a) is fulfilled should be evaluated primarily on the basis of the administrative outcome. ${ }^{490}$ The European Communities argues that "[a]part from the case that the administrative process is regulated in laws or regulations of general application themselves, the obligation of uniform administration only extends to the administrative process to the extent that the administrative process has a direct and significant impact on the outcome of the process." ${ }^{491}$ Accordingly, the European Communities requests the Appellate Body to reverse the Panel's finding that Article X:3(a) of the GATT 1994 requires uniformity of administrative processes irrespective of their impact on the uniform administration of the laws covered by Article X:1 of the GATT $1994 .^{492}$

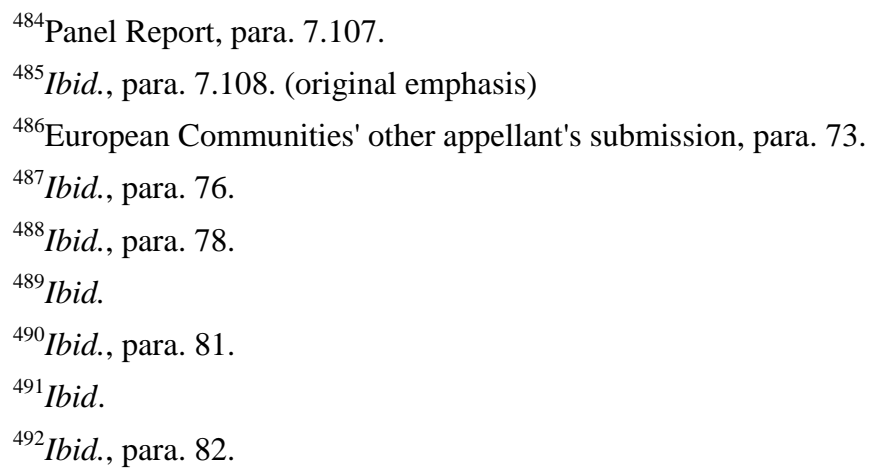


WT/DS315/AB/R

Page 86

222. The United States disagrees with the European Communities' view that "the obligation of uniform administration only extends to the administrative process to the extent that the administrative process has a direct and significant impact on the outcome of the process." ${ }^{493}$ The United States points out that the European Communities failed to explain what it means by "administrative outcome" and how to distinguish administrative outcomes from administrative processes. ${ }^{494}$ For the United States, the exclusion of administrative processes from the obligation of uniform administration has no basis in the text of Article X:3(a). ${ }^{495}$ The United States considers that the European Communities' approach is too restrictive and would imply that significant areas of customs administration could be carried out in a non-uniform manner without breaching Article X:3(a). ${ }^{496}$ According to the United States, whether requiring uniformity of administrative processes under Article X:3(a) would exclude de minimis variations in the administration of customs law is not an issue that arises in this dispute. ${ }^{497}$ Indeed, the United States maintains that, where the Panel found divergences in administrative processes inconsistent with Article X:3(a), the divergences were material to traders' decisions to convey goods into the European Communities through one region rather than through another. ${ }^{498}$

223. We first address the European Communities' contention that the Panel found that Article X:3(a) of the GATT 1994 requires uniformity of the administrative processes. ${ }^{499}$ We do not see such a finding in the Panel Report. The Panel found that the term "administer" in Article X:3(a) relates to administrative processes ${ }^{500}$, but it did not find that Article X.3(a) requires uniformity as regards administrative processes.

224. We turn to the question of whether the term "administer" in Article X:3(a) may include administrative processes and whether it requires uniformity of administrative processes. We agree with the Panel that the term "administer" may include administrative processes. In its broadest sense, an administrative process may be understood as a series of steps, actions, or events that are taken or occur in relation to the making of an administrative decision. Given this broad definition of administrative process, it appears to us that Article X:3(a) of the GATT 1994 does not contemplate uniformity of administrative processes. In other words, non-uniformity or differences in

\footnotetext{
${ }^{493}$ European Communities' other appellant's submission, para. 81.

${ }^{494}$ United States' appellee's submission, paras. 53-54.

${ }^{495}$ Ibid., para. 55.

${ }^{496}$ Ibid., para. 58.

${ }^{497}$ Ibid., paras. 60-61.

${ }^{498}$ Ibid., para. 61.

${ }^{499}$ European Communities' other appellant's submission, heading IV.B.

${ }^{500}$ Panel Report, para. 7.119.
} 
administrative processes do not, by themselves, constitute a violation of Article X:3(a). This Article contains an obligation to administer in a uniform manner legal instruments of the kind described in Article X:1-laws, regulations, judicial decisions, and administrative rulings of general application pertaining to the subject matters set out in that provision. We agree with the Panel that the term "administer" in Article X:3(a) refers to putting into practical effect, or applying, a legal instrument of the kind described in Article X:1. ${ }^{501}$ Thus, under Article X:3(a), it is the application of a legal instrument of the kind described in Article X:1 that is required to be uniform, but not the processes leading to administrative decisions, or the tools that might be used in the exercise of administration.

225. This does not mean that the characteristics of an administrative process are irrelevant for purposes of assessing whether a legal instrument of the kind described in Article X:1 is uniformly applied or put into practical effect in particular cases. The features of an administrative process that govern the application of a legal instrument of the kind described in Article X:1 may constitute relevant evidence for establishing uniform or non-uniform administration of that legal instrument. The probative value of such evidence will, however, depend on the circumstances of each case and will necessarily vary from case to case. Thus, we may conceive of cases where a panel might attach much weight to differences that exist at the level of the administrative processes, because it considers these differences to be so significant that they have caused, or are likely to cause, the non-uniform application of the legal instrument at issue. On the other hand, a panel might conclude, after an overall assessment of the evidence, that the consistent nature of the results of the application of the legal instrument shows that the measure at issue is administered in a uniform manner, even though differences may exist at the level of the administrative process.

226. As the term "administer" in Article X:3(a) may include the administrative processes, evidence relating to the features of an administrative process can be adduced in support of a claim of a violation of Article X:3(a). However, in order to substantiate a claim of violation based on an administrative process, it is not sufficient that the complainant merely recites the features of the administrative processes; it will also have to show how and why those features necessarily lead to a lack of uniform, impartial, or reasonable administration of a legal instrument of the kind described in Article X:1.

227. In the light of the foregoing consideration, we uphold the Panel's finding, in paragraph 7.119 of the Panel Report, that the term "administer" in Article X:3(a) of the GATT 1994 may include administrative processes that put into effect the legal instruments of the kind described in Article X:1 of the GATT 1994. We also find that Article X:3(a) of the GATT 1994 does not require uniformity of administrative processes.

${ }^{501}$ Panel Report, para. 7.104. 
WT/DS315/AB/R

Page 88

C. The Administrative Process Leading to the Tariff Classification of Blackout Drapery Lining

228. We address next the question whether the Panel erred in finding that the European Communities has violated Article X:3(a) of the GATT 1994 with respect to "the administrative process leading to the tariff classification of blackout drapery lining". ${ }^{502}$

229. Regarding the tariff classification of blackout drapery lining, the Panel did not find that the divergent classification decisions by, on the one hand, the German customs authorities and, on the other hand, the customs authorities in the United Kingdom, Ireland, the Netherlands, and Belgium amounted to non-uniform administration in violation of Article X:3(a) of the GATT 1994. ${ }^{503}$ However, the Panel noted that the "United States has also implicitly challenged the administrative process that led to divergent classification decisions regarding blackout drapery lining"504, and went on to assess the consistency with Article X:3(a) of the administrative process followed by the German customs authorities. Relying on decisions and letters in two cases, the Bautex-Stoffe GmbH case ("Bautex") and the Ornata GmbH case ${ }^{505}$, the Panel found that, with respect to the tariff classification of blackout drapery lining, the German customs authorities relied on an interpretative aid that is particular to Germany ${ }^{506}$ and that is not contained in the relevant chapters of the Common Customs Tariff. ${ }^{507}$ The Panel also noted that it "has not been provided with any evidence to indicate that any other member States are relying upon an aid akin to that used by the German customs authorities with respect to the tariff classification of blackout drapery lining." ${ }^{508}$ For the Panel:

... a system of customs administration which allows or, at least, does not prevent customs authorities from unilaterally relying upon interpretative aids in carrying out their functions, which are not provided for in the binding rules applicable to all customs authorities, such as in the European Communities, could lead to non-uniform administration in violation of Article X:3(a) of the GATT 1994 in certain circumstances. $^{509}$

\footnotetext{
${ }^{502}$ Panel Report, para. 7.276.

${ }^{503}$ Ibid., para. 7.265.

${ }^{504}$ Ibid. (original emphasis)

${ }^{505}$ Ibid., paras. 7.268-7.270.

${ }^{506}$ Ibid., para. 7.268.

${ }^{507}$ Ibid., para. 7.271.

${ }^{508}$ Ibid.

${ }^{509}$ Ibid., para. 7.267.
} 
On this basis, the Panel concluded that "the German customs authorities' reliance upon the interpretative aid in question amounts to non-uniform administration in violation of Article X:3(a) of the GATT 1994." ${ }^{1510}$

230. The Panel also observed:

[A] customs administration system which does not require reference by customs authorities to decisions taken by other customs authorities operating within the same system and/or cooperation between customs authorities before customs decisions are taken, such as in the European Communities, could lead to non-uniform administration in violation of Article X:3(a) of the GATT 1994 in certain circumstances. ${ }^{511}$ (original emphasis)

Relying on decisions and letters in the Bautex case, the Panel found that German customs authorities failed to consider seriously classification decisions for blackout drapery lining by other customs authorities. On this basis, the Panel concluded that "the treatment by the German customs authorities of classification decisions for blackout drapery lining issued by other customs authorities amounts to non-uniform administration in violation of Article X:3(a) of the GATT 1994."

231. The European Communities challenges in its other appeal the Panel's findings on the administrative process leading to the tariff classification of blackout drapery lining by the German customs authorities. The European Communities notes first that the Panel reached these findings "even though it also found that there was no evidence of an actual divergence in the tariff classification of [blackout drapery lining]." ${ }^{513}$ For the European Communities, the Panel erred because it overstepped its terms of reference by making findings with respect to expired measures, failed to make an objective assessment of the facts as required by Article 11 of the DSU, and misapplied the requirements in Article X:3(a) of the GATT 1994.

232. The European Communities argues that the findings of the Panel regarding blackout drapery lining are outside its terms of reference because they are based exclusively on the reasoning of the decisions and letters of the German customs authorities in two isolated cases. The European Communities point out that the letter of the Main Customs Office Hamburg to Ornata GmbH dates from July 1998, the opinion of the ZPLA Hamburg in the Bautex case dates from February 2003, and the decision of the Main Customs Office Hamburg in the same case dates from September $2004 .{ }^{514}$

\footnotetext{
${ }^{510}$ Panel Report, para. 7.271.

${ }^{511}$ Ibid., para. 7.272. (footnote omitted)

${ }^{512}$ Ibid., para. 7.275.

${ }^{513}$ European Communities' other appellant's submission, para. 95.

${ }^{514}$ Ibid., para. 106.
} 
WT/DS315/AB/R

Page 90

For the European Communities, these decisions and letters are expired measures, relate to past cases, and do not produce any effects for the future. ${ }^{515}$

233. The European Communities contends that the description of the facts made by the Panel with respect to the reliance by the German customs authorities on an interpretative aid that is particular to Germany does not correspond to an objective assessment of the facts, as required by Article 11 of the DSU. ${ }^{516}$ According to the European Communities, the decision of the Main Customs Office Hamburg in the Bautex case and the letter of the Bremen Main Customs Office to Ornata GmbH do not contain any explicit reference to the interpretative aid allegedly relied on by the German customs authorities, contrary to what the Panel suggested. ${ }^{517}$ With respect to the alleged failure of the German customs authorities to take into account the decisions of other customs authorities, the European Communities also contends that the assessment of the facts by the Panel is flawed. With respect to the statements made by the Bremen Main Customs Office and the Hamburg ZPLA regarding the classification decisions of other customs authorities, the European Communities explains that these statements give no indication that these customs authorities wished to dismiss the relevance of the classification decisions of customs authorities of other member States. ${ }^{518}$ According to the European Communities, the Panel ignored a letter from the Main Customs Office Hamburg to Ornata $\mathrm{GmbH}^{519}$, which clearly illustrates that the German customs authorities do take into account the practice of other customs authorities concerning the classification of similar goods when they are made aware of them. ${ }^{520}$

234. The European Communities considers that the Panel's findings are based on an assessment of the "motivation" of the decisions and letters that were issued by the German customs authorities ${ }^{521}$, and that such reasoning cannot properly be regarded as part of the "administrative process". ${ }^{22}$ In any event, not every divergence in the reasoning between the decisions of customs authorities could be regarded as amounting to non-uniform administration, because a violation of that obligation caused by differences in administrative process can only be assumed to exist where a divergence has a direct impact on administrative outcomes. ${ }^{523}$ In the European Communities' view, Article X:3(a) does not require that the reasoning of decisions by customs authorities be uniform, since this would be contrary

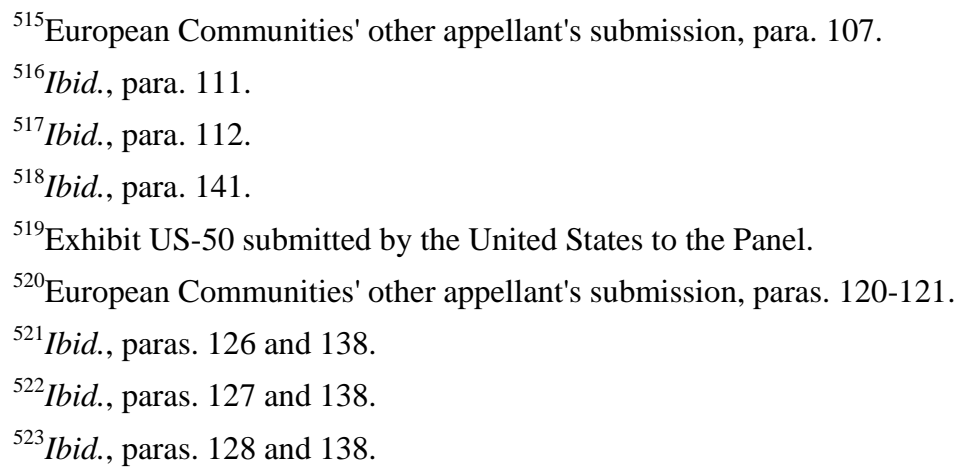


to the very purpose of the "motivation", which is to set out the reasons for the decision in the circumstances of the particular case. ${ }^{524}$

235. The United States submits that the Panel did not err in its findings regarding the tariff classification of blackout drapery lining. In the United States' view, the European Communities attempts to reargue certain factual issues and, in so doing, misrepresents the relevant facts. ${ }^{525}$ Regarding the European Communities' allegation that the Panel was wrong to state that all the decisions or letters of the German customs authorities regarding the classification of blackout drapery lining relied on the German interpretative aid, the United States points out that there was an explicit reference to that aid in the documents issued by the German customs authorities. ${ }^{526}$ The United States requests the Appellate Body not to disturb the Panel's factual findings or reweigh the evidence that was before it. ${ }^{527}$

236. The United States contends that the Panel correctly found that differences in the administrative processes leading to the classification of blackout drapery lining were inconsistent with Article X:3(a). The United States observes that the Panel did not find that differences between the blackout drapery lining presented to the German customs authorities and the blackout drapery lining presented to other customs authorities justified different tariff classifications; but, rather, that there was an absence of evidence to support a finding of divergent tariff classifications in Germany, on the one hand, and in other member States, on the other hand. ${ }^{528}$ The United States argues that a finding of insufficient evidence of divergent classification decisions is not the same as a finding that different customs authorities correctly reached different tariff classification decisions. According to the United States, the distinction the European Communities seeks to draw between the "motivation" of a decision and "administrative processes" is unfounded. ${ }^{529}$

237. The United States agrees with the Panel's finding that the German customs authorities failed to take into account the decisions of other customs authorities in the European Communities regarding the classification of blackout drapery lining. ${ }^{530}$ According to the United States, the German customs authorities are not required to refer to decisions taken by other customs authorities operating within

\footnotetext{
${ }^{524}$ European Communities' other appellant's submission, para. 19.

${ }^{525}$ United States' appellee's submission, para. 73.

${ }^{526}$ Ibid., para. 80.

${ }^{527}$ Ibid., para. 85.

${ }^{528}$ Ibid., para. 90.

${ }^{529}$ Ibid., para. 94.

${ }^{530}$ Ibid., para. 107.
} 
WT/DS315/AB/R

Page 92

the same system of European Communities customs administration. ${ }^{531}$ The United States considers it important that "the German customs authority by its own admission was aware of other authorities having classified 'comparable goods', yet gave scant consideration to such classification and apparently undertook no investigation of those other authorities' findings." 532

238. At the outset of our analysis, we observe that the Panel reached what seem to be two opposite conclusions on the tariff classification of blackout drapery lining by the German customs authorities. On the one hand, the Panel found that the decisions of the German customs authorities regarding the tariff classification of blackout drapery lining did not amount to non-uniform administration in violation of Article X:3(a) of the GATT 1994. Indeed, the Panel considered that, on the basis of the evidence before it, there was an objective factual basis that justified the German customs authorities to classify the product in a manner different from that of customs authorities in other member States. ${ }^{533}$ On the other hand, for the reasons we set out above, the Panel found that "the administrative process leading to the tariff classification of blackout drapery lining amounts to non-uniform administration within the meaning of Article X:3(a) of the GATT 1994." ${ }^{153}$ As a result of this finding, the Panel ultimately concluded that there was "a violation of Article X:3(a) of the GATT 1994 with respect to the tariff classification of blackout drapery lining". 535

239. As we explained in Section V.B of this Report, the term "administer" may include administrative processes, but this does not mean that Article X:3(a) of the GATT 1994 requires uniformity of administrative processes. In order to find that an administrative process has led to nonuniform administration of a measure under Article X:3(a), a panel cannot merely rely on identifying the features of an administrative process that it may view as non-uniform; a panel must go further and undertake an analysis to determine whether those features of the administrative process necessarily lead to non-uniform administration of a legal instrument of the kind described in Article X:1. ${ }^{536}$

240. In this case, the Panel highlighted and criticized the use by the German customs authorities of an interpretative aid that is particular to Germany ${ }^{537}$, as well as the absence of any formal requirement for the customs authorities in Germany to refer to the decisions of customs authorities of other

\footnotetext{
${ }^{531}$ United States' appellee's submission, para. 100 (quoting Panel Report, para. 7.272).

${ }^{532}$ Ibid., para. 102.

${ }^{533}$ Panel Report, para. 7.265.

${ }^{534}$ Ibid., para. 7.276 .

${ }^{535}$ Ibid.

${ }^{536}$ See our development on this issue in Section V.B of this Report.

${ }^{537}$ Panel Report, paras. 7.267-7.271.
} 
member States when classifying blackout drapery lining. ${ }^{538}$ In this respect, we observe that the Panel viewed the resort to an interpretative aid that is particular to Germany and the absence of any requirement to refer to tariff classification decisions issued in other member States as features of the administrative process that German customs authorities follow in making tariff classification decisions regarding blackout drapery lining. Irrespective of whether this characterization is correct, we note that the Panel did not explain how and why these two features of the administrative process would necessarily lead to non-uniform classification of blackout drapery lining.

241. Indeed, as we noted earlier, the Panel found that the divergent decisions regarding the tariff classification of blackout drapery lining by, on the one hand, the German customs authorities and, on the other hand, customs authorities in other member States were justified by an "objective factual basis" and, therefore, did not amount to non-uniform administration, in violation of Article X:3(a) of the GATT $1994 .{ }^{539}$ Given this opposite conclusion on the tariff classification decisions of the German customs authorities on blackout drapery lining, we fail to see how, on the basis of the aforesaid two features of the administrative process, the Panel could have come to the conclusion of a violation of Article X:3(a) of the GATT $1994 .^{540}$

242. Accordingly, we reverse the Panel's finding, in paragraphs 7.276 and 8.1(b)(iv) of the Panel Report, that the administrative process leading to the tariff classification of blackout drapery lining amounts to non-uniform administration within the meaning of Article X:3(a) of the GATT 1994, and that the European Communities has violated Article X:3(a) of the GATT 1994 with respect to the tariff classification of blackout drapery lining.

243. The European Communities also claims that the Panel's findings regarding the administrative process leading to the tariff classification of blackout drapery lining were not based on an objective assessment of the facts as required by Article 11 of the DSU. As we concluded that the Panel erred in finding a violation of Article X:3(a) of the GATT 1994 with respect to the tariff classification of blackout drapery lining, we do not consider it necessary, for purposes of resolving this dispute, to rule on whether the Panel's findings regarding the administrative process in question were based on an objective assessment of the facts, as required by Article 11 of the DSU.

\footnotetext{
${ }^{538}$ Panel Report, paras. 7.272-7.275.

${ }^{539}$ Ibid., para. 7.265.

${ }^{540}$ Ibid., para. 7.276 .
} 
WT/DS315/AB/R

Page 94

D. Tariff Classification of Liquid Crystal Display Flat Monitors with a Digital Video Interface

244. We now turn to the question whether the Panel erred in finding that the European Communities has violated Article X:3(a) of the GATT 1994 with respect to the tariff classification of liquid crystal display ("LCD") flat monitors with digital video interface ("DVI").

245. This issue concerns the tariff classification of LCD monitors with DVI that are shipped separately from computers. For these monitors, the question is whether they are to be classified as computer monitors or as video monitors. Video monitors fall under heading 8528 of the European Communities' Common Customs Tariff and are subject to a duty rate of 14 per cent. Computer monitors fall under heading 8471 of the Common Customs Tariff and are imported duty-free (as they are subject to the Information Technology Agreement). The classification of these monitors has acquired significance as a result of the increasing technological developments and the convergence of information technology and consumer electronics. Before the Panel, the United States challenged the divergence in the tariff classification of LCD monitors with DVI among the customs authorities of the member States of the European Communities.

246. The Panel found that "the tariff classification of LCD monitors with DVI amounts to nonuniform administration within the meaning of Article X:3(a) of the GATT 1994." ${ }^{541}$ The Panel relied on a divergence in the tariff classification of this product between, on the one hand, the customs authorities in the Netherlands, which classified LCD monitors with DVI as video monitors under heading 8528, and, on the other hand, customs authorities in other member States, which classified this product as computer monitors under heading 8471. The Panel also noted that the European Communities did not "appear to dispute" the existence of this divergence. ${ }^{542}$ The European Communities argued before the Panel that certain actions had been taken by the European Communities since 2004 to resolve the divergence in the tariff classification of LCD monitors with DVI among customs authorities of the member States. After analyzing the evidence placed

\footnotetext{
${ }^{541}$ Panel Report, para. 7.305.

${ }^{542}$ Ibid., para. 7.294 .
} 
before it ${ }^{543}$, the Panel concluded that "the action taken by the European Communities has not had the effect of rectifying the divergence in the tariff classification of LCD monitors with DVI among customs authorities of the member States." ${ }^{544}$

247. The Panel further noted "the existence of a draft Regulation [2171/2005] concerning the classification of LCD monitors contained in Exhibit EC-163". ${ }^{545}$ The Panel took the view that, "at the time the Panel issued its Interim Report to the parties, the Panel had not been provided with evidence to indicate that that draft regulation had the effect of removing [the] divergence in tariff classification of such monitors which became evident in 2004." ${ }^{\text {"56 }}$

248. In its comments on the Interim Report, the European Communities indicated to the Panel that the draft Regulation contained in Exhibit EC-163 had been adopted as Commission Regulation (EC) No. 2171/2005 ("EC Regulation 2171/2005") on 23 December 2005. It also informed the Panel that, following the adoption of that Regulation, the decree of 8 July 2005 issued by the Dutch customs authorities had been withdrawn and the German Binding Tariff Information ("BTI") dated 19 July 2005 had ceased to be valid. ${ }^{547}$ These comments of the European Communities at the interim review stage were supported by three new exhibits. ${ }^{548}$ The Panel declined to consider these exhibits on the ground that "the terms of Article 15.2 preclude[d] [it] from taking into consideration evidence which is not reflected in the Interim Report." 549

${ }^{543}$ This evidence included:

- Council Regulation (EC) No. 483/2005 of 16 March 2005 (Exhibit US-62 submitted by the United States to the Panel);

- Commission Regulation (EC) No. 634/2005 of 26 April 2005 (Exhibit EC-85 submitted by the European Communities to the Panel);

- an opinion of the Customs Code Committee taken at its 346th Meeting of 30 June-2 July 2004 (European Communities' first written submission to the Panel, para. 353); and

- Tariff Notice 13/04 issued by the customs authority of the United Kingdom (according to the Panel, apparently published following the issuance of the opinion of the Customs Code Committee); the decree of 8 July 2005 issued by the Dutch customs authority; and a BTI dated 19 July 2005 issued by the German customs authority; Letters respectively dated 2 September 2005 and 6 December 2005 from the Director-General of the European Information, Communications and Consumer Electronics Technology Industry Associations (EICTA) to a high-ranking official of the European Commission (Exhibits US-76, US-77, US-78, US-75, and US-81, respectively, submitted by the United States to the Panel).

${ }^{544}$ Panel Report, para. 7.304.

${ }^{545}$ Ibid., footnote 580 to para. 7.305 .

${ }^{546}$ Ibid.

${ }^{547}$ European Communities' comments on the Interim Panel Report, paras. 67 and 69.

${ }^{548}$ Exhibits EC-167, EC-168, and EC-169 submitted by the European Communities to the Panel.

${ }^{549}$ Panel Report, para. 6.6. 
WT/DS315/AB/R

Page 96

249. In its other appeal, the European Communities challenges the Panel's finding that "the tariff classification of LCD monitors with DVI amounts to non-uniform administration within the meaning of Article X:3(a) of the GATT 1994." ${ }^{n 50}$ For the European Communities, the Panel "overstepped its terms of reference by basing its findings of violation primarily on instances of administration which post-date its establishment". ${ }^{551}$ Specifically, the European Communities refers to the Dutch decree of 8 July 2005 and the German BTI of 19 July 2005. ${ }^{552}$ The European Communities also argues that the Panel did not make an objective assessment of the facts, as required by Article 11 of the DSU, because "the Panel did not have any evidence before it to support a finding that at the time of its establishment, there was a lack of uniform administration with regard to the tariff classification of LCD monitors." ${ }^{253}$ The European Communities contends that, "apart from one inconclusive press release by a law firm, the United States did not provide any evidence as to the [European Communities'] classification practice prior to the Panel's establishment." ${ }^{554}$

250. The European Communities considers that the Panel erred in finding a violation of Article X:3(a), even assuming that it was justified to consider "instances of administration which postdated ... its establishment". ${ }^{55}$ For the European Communities, uniformity under Article X:3(a) must be "established within a reasonable period of time" ${ }^{556}$, and maintains that this has been achieved with the adoption of EC Regulation 2171/2005 on 23 December 2005, as well as with the withdrawal, in January 2006, of the Dutch decree and the German BTI. ${ }^{557}$ In this respect, the European Communities asserts that the Panel erred in failing to take into account draft EC Regulation 2171/2005. In the European Communities' view, a regulation should not be ignored simply because it has not yet been adopted. $^{558}$ The European Communities also argues that the Panel erred in rejecting the evidence contained in exhibits provided by the European Communities at the interim review stage. ${ }^{559}$ Rejecting this evidence was not in accordance with Article 15.2 of the DSU because the evidence related to precise aspects of the Interim Report. ${ }^{560}$ The European Communities, therefore, requests the

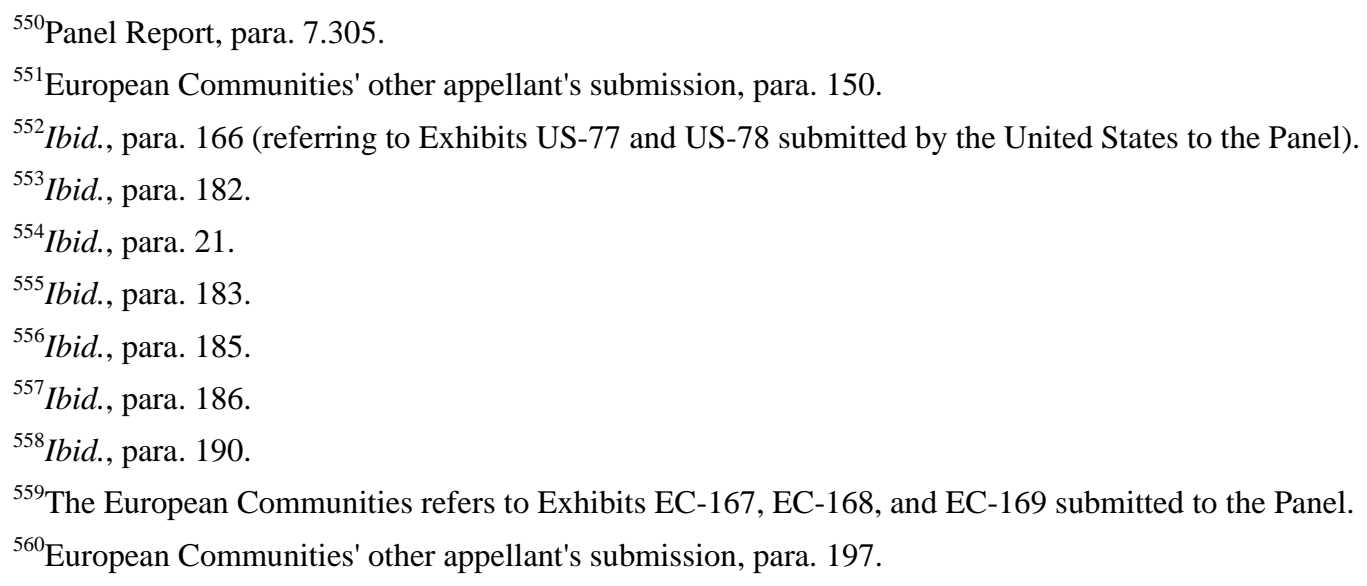


Appellate Body to "reverse the Panel's decision in paragraph 6.6 of the [Panel Report] not to admit the evidence contained in Exhibits EC-167, EC-168 and EC-169." ${ }^{561}$

251. The United States contends that the European Communities' other appeal misrepresents key facts and ignores the distinction between administration and evidence of administration. The United States also disagrees with the European Communities' argument that the Panel erred by declining to consider new evidence introduced only at the interim review stage. ${ }^{562}$

252. In the United States' view, the Panel made an objective assessment of the facts when it found that, in 2004, the European Communities acknowledged that tariff classification of LCD monitors with DVI was not uniform. ${ }^{563}$ The United States emphasizes that it had established this fact before the Panel and that various statements made by the European Communities in the course of the Panel proceedings suggested that "the [European Communities] was aware of the issue and was working to address it." ${ }^{164}$ The United States observes that the European Communities argued before the Panel that three steps were taken by European Communities institutions in order to address the non-uniform classification of LCD monitors with DVI (namely, "the June/July 2004 Customs Code Committee 'conclusions', the EU Council duty suspension regulation and EU Commission Regulation 634/2005"). ${ }^{565}$ The Panel analyzed each of these measures and found that none of them resolved the problem of non-uniform administration. ${ }^{566}$

253. For the United States, the Panel did not overstep its terms of reference by referring to acts of administration that post-dated the Panel's establishment, because the Panel referred to these acts as evidence of the manner of administration at the time of Panel establishment that is alleged to be inconsistent with Article X:3(a). According to the United States, the Dutch decree of 8 July 2005 and the German BTI of 19 July 2005 are relevant evidence supporting the Panel's finding that "measures put into place since 2004 have not resolved the problem of non-uniform administration and may well have increased confusion." 567 The United States contends that the Panel was correct to attribute no weight to draft EC Regulation 2171/2005 on LCD monitors and declined to consider new evidence

${ }^{561}$ European Communities' other appellant's submission, para. 201.

${ }^{562}$ United States' appellee's submission, para. 108.

${ }^{563}$ Ibid., para. 109.

${ }^{564}$ Ibid., para. 110.

${ }^{565}$ Ibid., para. 117.

${ }^{566}$ Ibid., para. 123 (referring to European Communities' first written submission to the Panel, paras. 351-353, 356, and 361).

${ }^{567}$ Ibid., para. 126 (referring to Panel Report, para. 7.300). 
WT/DS315/AB/R

Page 98

introduced by the European Communities at the interim review stage. ${ }^{568}$ Regarding the Panel's decision not to consider new evidence introduced at the interim review stage, the United States underlines that the interim review stage is not an appropriate time to introduce new evidence, and disagrees with the European Communities' assertion that there should be an exception for evidence introduced to correct errors of fact. ${ }^{569}$

254. As we explained above, had the Panel properly identified the measures at issue, its task would have been to determine whether the measures at issue had been administered collectively in a uniform manner at the time the Panel was established ${ }^{570}$, that is to say, in March 2005. In order to make this determination, the Panel could rely on evidence that pre-dated or post-dated the time of the Panel's establishment to the extent that it was evidence relevant for the assessment of whether the European Communities acted consistently with Article X:3(a) at the time of the Panel's establishment. ${ }^{571}$ In our view, the Panel did not err in referring, in its analysis, to "evidence related to instances of administration which occurred after its establishment ${ }^{1572}$, because this evidence was relevant to the task of determining whether there was a violation of Article X:3(a) at the time of the establishment of the Panel. The Dutch decree of 8 July 2005 and the German BTI of 19 July 2005 had come into existence within a short time after the establishment of the Panel. In our view, it was not unreasonable for the Panel to consider that this evidence was relevant for assessing how the measures at issue were administered at the time the Panel was established. Accordingly, we reject the European Communities' argument that the Panel "overstepped its terms of reference by basing its findings of violation primarily on instances of administration which post-date its establishment." ${ }^{573}$

255. Another point raised by the European Communities' other appeal is whether the Panel failed to make an objective assessment of the facts, as required by Article 11 of the DSU, because it did not have any evidence before it to support a finding that, at the time of the establishment of the Panel, there was a lack of uniform administration with regard to the tariff classification of LCD monitors with DVI. However, the Panel Report shows that the Panel did analyze various pieces of evidence and came to the conclusion that the divergence in tariff classification of LCD monitors with DVI,

${ }^{568}$ United States' appellee's submission, paras. 128, 132, and 140 (referring, inter alia, to Exhibits EC-167, EC-168, and EC-169 submitted by the European Communities to the Panel).

${ }^{569}$ Ibid., paras. 134-136 (referring to Appellate Body Report, EC - Sardines, para. 301).

${ }^{570}$ See Section IV.D of this Report. As we concluded in Section IV.B, the measures at issue in this dispute are the Community Customs Code, the Implementing Regulation, the Common Customs Tariff, and the TARIC, as administered collectively.

${ }^{571}$ See Section IV.D of this Report.

${ }^{572}$ European Communities' other appellant's submission, para. 166.

${ }^{573}$ Ibid., para. 150. 
found to have existed in 2004, had not been subsequently rectified. ${ }^{574}$ The Panel's analysis of the evidence also shows that some confusion did indeed exist in 2004 and 2005 among customs authorities of the member States on the tariff classification of LCD monitors with DVI, and that this confusion might also have caused divergences in tariff classification. ${ }^{575}$

256. Thus, it seems to us not correct to state, as the European Communities does, that "the Panel did not have any evidence before it to support a finding that at the time of its establishment, there was a lack of uniform administration with regard to the tariff classification of LCD monitors." ${ }^{576}$ The Panel did analyze various pieces of evidence, and we see nothing in the Panel's examination, weighing, and analysis of the evidence relating to the tariff classification of LCD monitors with DVI that would amount to a violation of its duty to make "an objective assessment of the facts" within the meaning of Article 11 of the DSU.

257. Finally, we turn to the last question raised by the European Communities' other appeal, namely, whether the Panel erred in failing to take into account draft EC Regulation 2171/2005, and in declining to consider Exhibits EC-167, EC-168, and EC-169 submitted by the European Communities at the interim review stage.

258. With respect to draft EC Regulation 2171/2005, we disagree with the European Communities that the Panel did not consider this draft Regulation. Draft EC Regulation 2171/2005 was discussed by the Panel in footnote 580 to paragraph 7.305 of the Panel Report. The European Communities might have wished the Panel had attached more weight than it did to this piece of evidence. It is, however, well-established that the weighing of the evidence is, in principle, within the discretion of the panel as the trier of facts. ${ }^{577}$ Thus, the Panel was "not required to accord to factual evidence of the parties the same meaning and weight as do the parties". ${ }^{578}$ We also recall that "a mere divergence of views between a party and a panel on the inferences to be drawn from pieces of evidence is not a sufficient ground to conclude that the Panel failed to 'make ... an objective assessment of the facts of the case'.".579

259. With respect to Exhibits EC-167, EC-168, and EC-169 (which relate to the adoption of EC Regulation 2171/2005 and its consequences), we are of the view that the Panel did not err in

\footnotetext{
${ }^{574}$ This evidence is presented supra, footnote 543 .

${ }^{575}$ Panel Report, paras. 7.300-7.303.

${ }^{576}$ European Communities' other appellant's submission, para. 182. (emphasis added)

${ }^{577}$ See Appellate Body Report, EC - Bed Linen (Article 21.5 - India), para. 181.

${ }^{578}$ Appellate Body Report, Japan - Apples, para. 221; Appellate Body Report, Australia - Salmon,

${ }^{579}$ Appellate Body Report, Dominican Republic - Import and Sale of Cigarettes, para. 84.
} para. 267. 
WT/DS315/AB/R

Page 100

declining to consider these pieces of evidence. ${ }^{580}$ As the Appellate Body stated in EC - Sardines, "[t]he interim review stage is not an appropriate time to introduce new evidence." 581 The Panel's decision to decline to consider Exhibits EC-167, EC-168, and EC-169 appears to us to be in line with the Appellate Body's statement in EC - Sardines that "only ... 'precise aspects' of the [interim] report ... must be verified during the interim review ... [a]nd this ... cannot properly include an assessment of new and unanswered evidence." ${ }^{582}$ In any event, although Exhibits EC-167, EC-168, and EC-169 might have arguably supported the view that uniform administration had been achieved by the time the Panel Report was issued, we fail to see how these exhibits showed uniform administration at the time of the establishment of the Panel.

260. In the light of the above considerations, we uphold the Panel's finding, in paragraphs 7.305 and 8.1(b)(v) of the Panel Report, that "[t]he tariff classification of liquid crystal display monitors with digital video interface amounts to non-uniform administration within the meaning of Article X:3(a) of the GATT 1994."

\section{E. Administration of the Successive Sales Provision}

261. We now turn to the question whether the European Communities' administration of the successive sales provision (Article 147(1) of the Implementing Regulation) ${ }^{583}$ leads to a violation of Article X:3(a) of the GATT 1994 because some member States of the European Communities impose a "form of prior approval" requirement while others do not.

\footnotetext{
${ }^{580}$ See Panel Report, para. 6.6.

${ }^{581}$ Appellate Body Report, EC - Sardines, para. 301.

${ }^{582}$ Ibid.
}

${ }^{583}$ Article 147 of the Implementing Regulation sets out the conditions under which a sale other than the last sale that led to the introduction of the goods into the European Communities may be used as the basis for the valuation of the goods. It provides, in relevant part:

For the purposes of Article 29 of the Code, the fact that the goods which are the subject of a sale are declared for free circulation shall be regarded as adequate indication that they were sold for export to the customs territory of the Community. In the case of successive sales before valuation, only the last sale, which led to the introduction of the goods into the customs territory of the Community, or a sale taking place in the customs territory of the Community before entry for free circulation of the goods shall constitute such indication.

Where a price is declared which relates to a sale taking place before the last sale on the basis of which the goods were introduced into the customs territory of the Community, it must be demonstrated to the satisfaction of the customs authorities that this sale of goods took place for export to the customs territory in question. 
262. The Panel concluded:

The imposition by customs authorities in some member States of a form of prior approval with respect to the successive sales provision, which is inconsistent with [European Communities] customs law and which is not imposed by customs authorities in other member States means that the European Communities does not administer its customs law concerning successive sales-in particular, Article 147(1) of the Implementing Regulation-in a uniform manner in violation of Article X:3(a) of the GATT $1994 .{ }^{584}$

263. In reaching its conclusion, the Panel relied on the European Communities' Court of Auditors Special Report No. 23/2000 concerning valuation of imported goods for customs purposes ${ }^{585}$ (the "Court of Auditors Report") submitted by the United States to the Panel as Exhibit US-14. The Court of Auditors Report suggests that, "in practice, some customs authorities do impose a form of prior approval even though this has no basis in [European Communities] law." At the same time, however, the European Commission, it its replies to the Court of Auditors Report, contests the Court of Auditors' assertion that, "in practice, some customs authorities do impose a form of prior approval". ${ }^{586}$ The Panel Report reflects that the Panel took into account the Court of Auditor's statement that only some customs authorities impose a "form of prior approval". However, it is not clear from the Panel Report that the Panel also took into account the European Commission's replies to the Court of Auditors Report, which are an integral part of Exhibit US-14. The Panel considered that, since the United States had presented a section of the Court of Auditors Report to sustain its claim, it was incumbent on the European Communities to submit evidence to rebut the Court of Auditors' assertion.

The Panel stated:

$\ldots$ at the time the Panel issued its Interim Report to the parties, the European Communities had not submitted any evidence to substantiate its assertion in this regard.* ${ }^{587}$

\footnotetext{
*The Panel considers that it was incumbent upon the European Communities to submit such evidence in the light of aspects of the [European Communities'] Court of Auditor's report referred to in paragraph 7.383 above, which tend to call the European Communities assertion in this regard into question.
}

${ }^{584}$ Panel Report, para. 7.385.

${ }^{585}$ Court of Auditors Report, supra, footnote 207.

${ }^{586}$ The Commission's replies are published together with the Court of Auditors Report pursuant to Article 248(4) second subparagraph of the EC Treaty.

${ }^{587}$ Panel Report, para. 7.382 and original footnote 671 thereto. 
WT/DS315/AB/R

Page 102

264. On appeal, the European Communities claims that the Panel "unduly shifted the burden of proof from the United States to the European Communities" to establish whether or not there was a lack of uniformity in the application of Article 147(1) of the Implementing Regulation. In the European Communities' view, the United States had not established a prima facie case of violation of Article X:3(a) of the GATT 1994 with respect to the administration of the successive sales provision. The European Communities also submits that, by shifting the burden of proof, the Panel failed to make an objective assessment of the matter before it as required by Article 11 of the DSU. ${ }^{58}$

265. In the view of the United States, the statement in the Court of Auditors Report that, "in practice, some customs authorities do impose a form of prior approval even though this has no basis in Community law"589, amounts to an admission of non-uniform administration by the European Communities. ${ }^{590}$ The United States considers that it did not need to adduce additional evidence in order to establish its prima facie case, given that it had provided the Panel with an admission by the European Communities. ${ }^{591}$

266. We begin our analysis by recalling that the Appellate Body addressed the question of allocation of the burden of proof in US - Wool Shirts and Blouses. In that case, the Appellate Body held:

The burden of proof rests upon the party, whether complaining or defending, who asserts the affirmative of a particular claim or defence. If that party adduces evidence sufficient to raise a presumption that what is claimed is true, the burden then shifts to the other party, who will fail unless it adduces sufficient evidence to rebut the presumption. (footnote omitted)

In the context of the GATT 1994 and the WTO Agreement, precisely how much and precisely what kind of evidence will be required to establish such a presumption will necessarily vary from measure to measure, provision to provision, and case to case. ${ }^{592}$

\footnotetext{
${ }^{588}$ European Communities' other appellant's submission, para. 214.

${ }^{589}$ Court of Auditors Report, supra, footnote 207, para. 64; Panel Report, para. 7.381.

${ }^{590}$ United States' appellee's submission, para. 143.

${ }^{591}$ Ibid., para. 147.

${ }^{592}$ Appellate Body Report, US - Wool Shirts and Blouses, p. 14, DSR 1997:I, 323, at 335.
} 
267. The Appellate Body defined the nature of a prima facie case in EC-Hormones. It stated:

[A] prima facie case is one which, in the absence of effective refutation by the defending party, requires a panel, as a matter of law, to rule in favour of the complaining party presenting the prima facie case. ${ }^{593}$ (footnote omitted)

268. Bearing this in mind, we examine whether the United States had established a prima facie case in assessing non-uniform administration of the successive sales provision. The United States submitted to the Panel one document to substantiate its claim, that is, Exhibit US-14. ${ }^{594}$ Exhibit US-14 contains two opposing statements: first, the Court of Auditors Report suggests that, in practice, some customs authorities do impose a form of prior approval even though this has no basis in European Communities law; and second, the European Commission's replies to the Court of Auditors Report, in which the Commission contests the Court of Auditor's assertion by saying that "customs authorities in some member States do not 'impose' such a notification". 595 The Court of Auditors Report and the Commission's replies are contained in the same document submitted to the Panel as Exhibit US-14. Given this rebuttal, we cannot agree with the United States that Exhibit US-14 amounts to an admission by the European Communities of the fact that some member States impose a prior approval requirement in the administration of the successive sales provision.

${ }^{593}$ Appellate Body Report, EC - Hormones, para. 104. See also Appellate Body Report, US - Wool Shirts and Blouses, p. 14, DSR 1997:I, 323, at 335.

The Appellate Body has subsequently relied on this statement in various instances. (See, for example, Appellate Body Report, US - Zeroing (EC), para. 217; and Appellate Body Report, Mexico - Anti-Dumping Measures on Rice, para. 167 and footnote 160 thereto)

${ }^{594}$ The Court of Auditors Report states, in relevant part:

The Court was unable to identify the full extent to which importers use or seek to use the successive sales provision. One reason for this is that, in order to apply the successive sales provision, unlike some other customs provisions, there is no legal requirement for an importer to obtain prior permission or authorisation. However, the Court found that, in practice, some customs authorities do impose a form of prior approval even though this has no basis in Community law. As in other aspects of customs valuation the Court found variations in the extent to which customs authorities allow the use of the provision or consult with each other. The Court has established that certain importers use the successive sales provision in one or more Member States but not in others and has drawn some significant examples of inconsistency to the attention of the Commission.

The Commission's view is that customs authorities in some Member States do not 'impose' such a notification.

(Court of Auditors Report, supra, footnote 207, para. 64, and Commission's replies thereto, p. 17)

${ }^{595}$ European Commission's comments on paragraphs 62-64 of the Court of Auditors Report, supra, footnote 207, p. 16. 
WT/DS315/AB/R

Page 104

269. Furthermore, we observe that the United States has not provided sufficient evidence for its assertion. It has not specified, for example, which member States impose "a form of prior approval"; what "forms of prior approval" the customs authorities of those member States impose; or how frequently such a requirement has been imposed. In addition, the United States has made no specific reference to instances of administration of the successive sale provision, or given examples where prior approval was imposed by, or would have been required by, a member State in practice.

270. In the light of these considerations, we disagree with the Panel that the United States has established a prima facie case with respect to its claim alleging lack of uniform administration of the successive sales provision. We therefore reverse the Panel's finding, in paragraphs 7.385 and 8.1(c)(ii) of the Panel Report, that "the European Communities does not administer its customs law concerning successive sales—in particular, Article 147(1) of the Implementing Regulation-in a uniform manner, in violation of Article X:3(a) of the GATT 1994." In the light of this finding, we do not consider it necessary, for purposes of resolving this dispute, to rule on whether the Panel's finding with respect to the administration of the successive sales provision was based on an objective assessment of the matter as required by Article 11 of the DSU.

\section{F. $\quad$ Completing the Analysis with respect to the "As a Whole" Challenge of the United States under Article X:3(a) of the GATT 1994}

271. We now examine whether the Appellate Body is in a position to complete the analysis and to determine whether the measures at issue (that is, the Community Customs Code, the Implementing Regulation, the Common Customs Tariff, and the TARIC), collectively or "as a whole", are administered by the European Communities in a manner inconsistent with its obligation under Article X:3(a) of the GATT 1994.

272. The Panel concluded that, "based on the language and content of the Panel's terms of reference, the Panel is precluded from considering 'as such' challenges of the design and structure of the [European Communities'] system of customs administration as a whole and also the design and structure of the [European Communities'] system in the areas of customs administration that have been specifically identified in the [panel request]." ${ }^{596}$ For the reasons we set out in Section IV.C of this Report, we reversed this finding of the Panel. In our view, the terms of the panel request indicate that the United States properly made a claim that the Community Customs Code, the Implementing Regulation, the Common Customs Tariff, and the TARIC, collectively, are administered in a nonuniform manner, in violation of Article X:3(a) of the GATT 1994. The Panel should have examined

\footnotetext{
${ }^{596}$ Panel Report, para. 7.64.
} 
this claim, but it did not. Consequently, we have now to determine whether we are in a position to complete the analysis with respect to the United States' claim under Article X:3(a) of the GATT 1994.

273. The United States is of the view that the Appellate Body should complete the analysis, and find that the European Communities' system of customs administration "as a whole" is inconsistent with Article X:3(a). ${ }^{597}$ For the United States, in this dispute, "a reversal of the Panel's findings without a completion of the Panel's analysis would fail 'to secure a positive solution to [the] dispute."'598 The United States submits that the analysis can be completed on the basis of undisputed facts and the Panel's findings of fact regarding the European Communities' system of customs administration. ${ }^{599}$ The United States recalls that "[t]he crux of the [United States'] claim ... was that the existence of a system of customs administration in which 25 separate, independent authorities exercise judgment in interpreting and applying [European Communities] customs law, without any procedures or institutions to ensure against divergences or to reconcile them promptly and as a matter of right when they occur necessarily constitutes a lack of uniform administration, in breach of Article X:3(a)." 600 The United States points to statements made by the Panel with respect to various mechanisms and institutions in the European Communities that, according to the European Communities, ensure against divergences or reconcile them when they occur. ${ }^{601}$ The United States also refers to the Panel's "overall assessment" that the European Communities system of customs administration "as a whole" is "complicated and, at times, opaque and confusing". ${ }^{602}$ According to the United States, by these statements, the Panel rejected the European Communities' argument that the institutions and procedures to which the European Communities referred ensure the uniform administration of European Communities customs law. ${ }^{603}$ For the United States, in the light of the Panel's statements regarding "the institutions and mechanisms the [European Communities] held out as securing uniform administration of [European Communities] customs law, completion of the Panel's analysis should be straightforward"604, and should lead to the conclusion that "the [European Communities'] system of customs administration as a whole is inconsistent with the [European Communities'] obligation of uniform administration under Article X:3(a) of the GATT 1994." 605

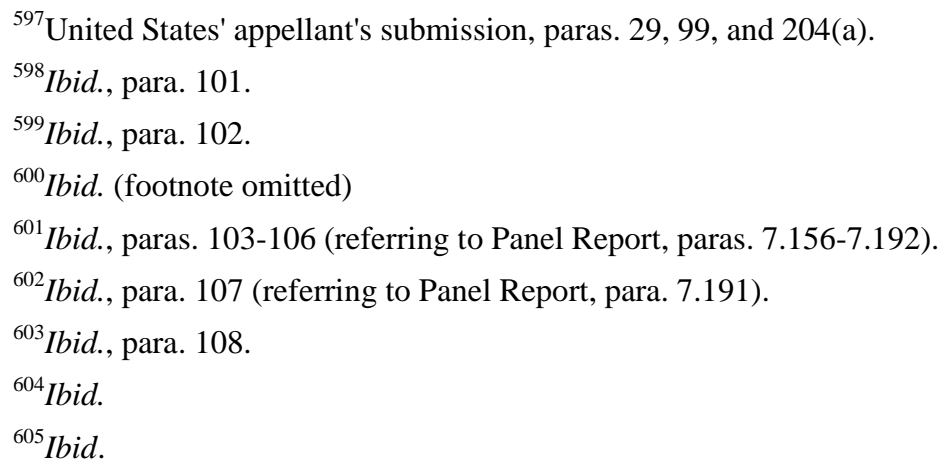


WT/DS315/AB/R

Page 106

274. The European Communities disagrees with the United States that there are enough factual findings made by the Panel, or undisputed facts on record, that would enable the Appellate Body to make the finding requested by the United States regarding the European Communities' system of customs administration "as such" and "as a whole". According to the European Communities, the Panel's statements to which the United States refers are isolated remarks in the Panel Report where the Panel comments on individual aspects of the European Communities' system of customs administration. ${ }^{606}$ These comments, the European Communities argues, do not allow the Appellate Body to assess whether the European Communities' system of customs administration "as a whole" and "as such" is in conformity with Article X:3(a) of the GATT 1994, because they do not contain findings of fact with respect to the European Communities' system of customs administration, and were not intended by the Panel to constitute such findings. ${ }^{607}$ The European Communities observes that these comments are contained in a section of the Panel Report where the Panel set out its understanding of the European Communities' system of customs administration as "context" for the evaluation of the United States' claims regarding individual instances of application. ${ }^{608}$ The European Communities also emphasizes that, if the United States' challenge concerns the European Communities' system of customs administration as a whole, then the "system must be evaluated with all its constituent interlocking elements and mechanisms, and not individual elements in isolation."609

275. Furthermore, the European Communities emphasizes that, in paragraph 7.490 of the Panel Report, the Panel observed, inter alia, that "the United States did not demonstrate that the design and structure of the [European Communities'] system of customs administration, including components thereof, necessarily result in a violation of Article X:3(a) of the GATT 1994." Thus, according to the European Communities, the Panel found that "the [United States] has not even come close to establishing that the [European Communities'] system 'as such' and 'as a whole' entails a violation of Article X:3(a) [of the] GATT." 610

276. Finally, the European Communities submits that the United States' claim regarding the European Communities' system of customs administration "as a whole" is a claim that has not been explored by the Panel, and on which the Panel has therefore not made any legal findings and interpretations that the Appellate Body could reverse. For the European Communities, a claim of violation of the obligation of uniform administration directed against individual instances of application is fundamentally different from a claim directed against a system of customs

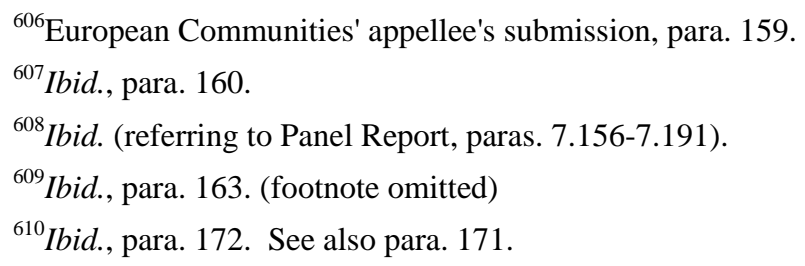


administration "as such" and "as a whole". ${ }^{611}$ Adjudging the claim regarding the European Communities' system of customs administration "as such" and "as a whole" would, therefore, violate the due process rights of the participants, and of the European Communities in particular. ${ }^{612}$

277. In response to questioning at the oral hearing, the United States confirmed that it does not consider that Article X:3(a) requires a centralized system of customs administration at the European Communities level. Therefore, for the United States, the administration of European Communities customs law by 25 national customs authorities does not, in itself, constitute a breach of Article X:3(a). According to the United States, the structural shortcoming that undermines the European Communities' system of customs administration is, rather, the absence of "any procedures or institutions to ensure against divergences or to reconcile them promptly and as a matter of right when they occur." ${ }^{613}$ The United States contends that the absence of any procedures, institutions, or mechanisms to ensure uniform administration necessarily results in a breach of Article X:3(a) of the GATT 1994 by the European Communities. ${ }^{614}$

278. It is well settled that the Appellate Body will be in a position to complete the legal analysis if it has before it sufficient factual findings of the panel or undisputed facts on the panel record. ${ }^{615}$ In this case, the Panel did not examine the United States' claim that the measures at issue, collectively, are administered in a non-uniform manner. Therefore, we have to consider whether the factual findings or general observations made by the Panel with respect to the claims it did examine, can be utilized in the context of completing the analysis. In considering this question, we also have to take into account the nature and breadth of the United States' challenge, that is, whether the Community Customs Code, the Implementing Regulation, the Common Customs Tariff, and the TARIC, collectively, are administered in a non-uniform manner, in violation of Article X:3(a) of the GATT 1994.

279. We begin our analysis by noting that, before the Panel, the European Communities referred to certain institutions and mechanisms existing in the European Communities to secure uniformity of administration of European Communities customs law. According to the European Communities, these institutions and mechanisms play "an instrumental role in achieving uniform administration of

\footnotetext{
${ }^{611}$ European Communities' appellee's submission, paras. 188-189.

${ }^{612}$ Ibid., paras. 193-195.

${ }^{613}$ United States' appellant's submission, para. 102.

${ }^{614}$ Ibid. See also paras. 2, 19, 21, and 69; United States' opening statement at the oral hearing; and United States' response to Question 126 posed by the Panel, Panel Report, pp. B-4 and B-5.

${ }^{615}$ See Appellate Body Report, US - Hot-Rolled Steel, para. 235; Appellate Body Report, Canada Dairy (Article 21.5 - New Zealand and US), para. 98; and Appellate Body Report, US - Section 211
} Appropriations Act, para. 343. 
WT/DS315/AB/R

Page 108

[European Communities] customs law by the customs authorities of the member States."616 The Panel took the view that it was not authorized to make any findings in relation to these institutions and mechanisms given that it had found that its terms of reference precluded it from considering challenges to the design and structure of the European Communities' system of customs administration, including components thereof. ${ }^{617}$ Nevertheless, the Panel chose to discuss these institutional mechanisms in a section of the Panel Report entitled "Relevant Aspects of the EC System of Customs Administration". It did so because it was of the view that "its understanding of certain aspects of the manner in which the [European Communities'] system of customs administration functions ... is important context for the examination of the particular instances of alleged violations of Article X:3(a) of the GATT 1994 in respect of which such aspects have been raised." ${ }^{618}$

280. The institutions and mechanisms of the European Communities' system of customs administration that the Panel addressed include the following: (i) the Customs Code Committee; (ii) Article 10 of the EC Treaty; (iii) the preliminary reference system (Article 234 of the EC Treaty); (iv) infringement proceedings; (v) the European Ombudsman; (vi) complaints to the European Commission; (vii) restrictions on the adoption of national measures by customs authorities of the member States; (viii) consultations and mutual assistance between member State customs authorities; and (ix) best practice guidelines, such as the European Binding Tariff Information (the "EBTI") guidelines, which refer to the EBTI database, and the Compendium of Customs Valuation texts.

281. The European Communities identified the Customs Code Committee as "an important institution that helps to ensure uniform administration of [European Communities] customs law among the customs authorities of the member States." ${ }^{19}$ The Panel noted that "the opinions of the Customs Code Committee are not legally binding on the customs authorities of the member States."620 After considering certain other features of the Community Customs Code, the Panel concluded that "it would appear that the Customs Code Committee has limited power to impose uniform administration of [European Communities] customs law on customs authorities of the member States."621

\footnotetext{
${ }^{616}$ Panel Report, para. 7.489.

${ }^{617}$ Ibid., para. 7.490 .

${ }^{618}$ Ibid., para. 7.155. (emphasis added)

${ }^{619}$ Ibid., para. 7.157. (footnote omitted)

${ }^{620}$ Ibid., para. 7.160.

${ }^{621}$ Ibid. (footnote omitted)
} 
282. With respect to the "duty of cooperation" contained in Article 10 of the EC Treaty, the Panel observed that "the extent to which Article 10 of the EC Treaty contributes to the uniform administration of [European Communities] customs law is unclear." ${ }^{n 22}$ The European Communities also cited Article 234 of the EC Treaty, according to which national courts of the member States may refer any question regarding the interpretation of European Communities law to the ECJ (the preliminary reference system). The European Communities submitted that "it is through preliminary rulings issued by the ECJ, which are binding on all courts of the member States, that divergences ... can be avoided and the effective application of European Communities law be assured." ${ }^{623}$ The Panel noted, however, that "a trader is not authorized under [European Communities] law to proceed directly to the ECJ for a preliminary ruling"624, and that "the use of the preliminary reference system to secure uniform administration ... in the area of customs administration during the period of 19952005 appears low." 625

283. With respect to the infringement proceedings that may be instituted before the ECJ against member States for failure to fulfil an obligation under European Communities law, and the role played by the European Ombudsman, the Panel noted that the use of both mechanisms appeared to be "low"626, and opined that "the extent to which the European Ombudsman is effective in ensuring uniform administration ... is unclear." ${ }^{1627}$ The Panel made observations that were largely descriptive in nature with respect to: the possibility of bringing a complaint to the European Commission; the existence of restrictions on the adoption of national measures by customs authorities of the member States; the mechanisms of consultation and mutual assistance between member State customs authorities; and best practice guidelines. In particular, the Panel noted that the customs authorities of the member States are not obliged to consult with one another before making customs decisions ${ }^{628}$, that there is no obligation on the part of customs authorities of the member States to consult the EBTI database when they classify a good ${ }^{629}$, and that "the commentaries contained in the Compendium of Customs Valuation texts have no legal status and, therefore, do not have binding effect." ${ }^{\text {"30 }}$

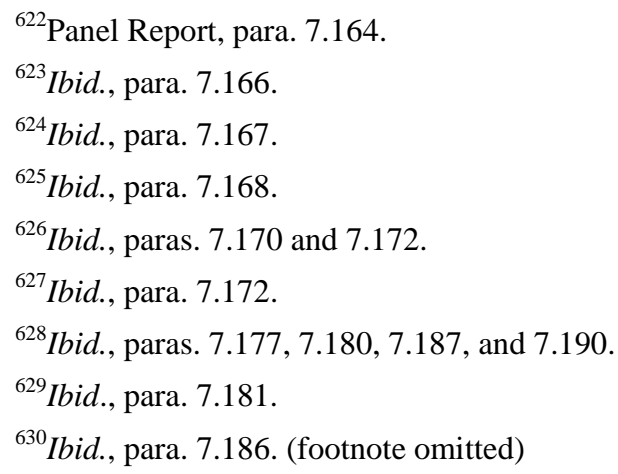


WT/DS315/AB/R

Page 110

284. Finally, under a section of the Panel Report entitled "General observations regarding the institutions and mechanisms involved in the administration of the EC customs laws", the Panel noted that, "in its consideration of the [European Communities'] system of customs administration as a whole, the Panel found the system complicated and, at times, opaque and confusing." ${ }^{631}$ Later, in a section entitled, "Overall observations regarding the United States' allegations of non-uniform administration under Article X:3(a) of the GATT 1994", the Panel observed that "certain features associated with a number of those institutions and mechanisms would not necessarily enhance uniform administration of [European Communities] customs law by the customs authorities of the member States and, at worst, might even cause non-uniform administration." ${ }^{632}$

285. From the description of the institutions and mechanisms involved in the administration of the European Communities customs law provided in paragraphs 7.157 to 7.191 of the Panel Report, it appears that there are institutions and mechanisms in the European Communities that seek to ensure that divergences in administration among the customs authorities of the member States do not occur or are reconciled in the event that they do occur. What is less clear from these general observations is whether the Panel made factual findings or reached definitive conclusions with respect to these institutions and mechanisms. Certainly, the Panel raised doubts about the effectiveness of these institutions and mechanisms in bringing about uniformity of administration of European Communities customs law. However, the Panel did not find that these institutions and mechanisms are structurally flawed in such a way that the European Communities' system of customs administration would necessarily lead to non-uniform administration, in a violation of Article X:3(a) of the GATT 1994. On the contrary, the Panel stated that, "even if the Panel were authorized to make such findings, ... the United States did not demonstrate that the design and structure of the [European Communities] system of customs administration, including components thereof necessarily result in a violation of Article X:3(a) of the GATT 1994." ${ }^{\text {"33 }}$ Accordingly, it appears to us that these general observations of the Panel do not constitute a sufficient foundation of factual findings or undisputed facts upon which we can rely for completing the analysis.

286. Further, as we said above, these general observations by the Panel with respect to the institutions and mechanisms involved in the administration of European Communities customs law were made in the context of an analysis based on the Panel's narrow interpretation of the measure at issue and the claim set out in the panel request. ${ }^{634}$ We have reversed this interpretation of the Panel.

\footnotetext{
${ }^{631}$ Panel Report, para. 7.191.

${ }^{632}$ Ibid., para. 7.489 .

${ }^{633}$ Ibid., para. 7.490.

${ }^{634}$ Ibid., para. 7.33.
} 
Therefore, the general observations made by the Panel in paragraphs 7.157 to 7.191 of the Panel Report do not provide a sufficient foundation for us to complete the analysis. Moreover, the Panel examined the operation of these institutions and mechanisms in isolation and did not discuss how these institutions and mechanisms interact in the administration of European Communities customs law. Finally, given the breadth and the nature of the claim set out by the United States in the panel request, we are of the view that paragraphs 7.157 to 7.191 of the Panel Report do not constitute a sufficient basis to enable us to complete the analysis.

287. In the light of all these considerations, we are unable to complete the analysis.

\section{The Panel's Interpretation of Article X:3(b) of the GATT 1994}

288. We now turn to the question whether Article X:3(b) of the GATT 1994 requires that decisions of the judicial, arbitral, or administrative tribunals, or procedures for the review and correction of administrative action relating to customs matters, must govern the practice of all the agencies entrusted with administrative enforcement throughout the territory of a particular WTO Member.

289. The Panel found:

[N]either the ordinary meaning of the various terms of Article X:3(b) of the GATT 1994 nor the legal context for the interpretation of Article X:3(b) of the GATT 1994 provide a clear answer to the specific question the Panel has been called upon to address-namely, whether Article X:3(b) of the GATT 1994 requires the decisions of the judicial, arbitral or administrative tribunals or procedures for the review and correction of administrative action relating to customs matters to govern the practice of all the agencies entrusted with administrative enforcement throughout the territory of a particular [WTO] Member. ${ }^{635}$ (original emphasis)

290. The Panel considered, however, that it would not be "reasonable" to infer that first instance independent review tribunals and bodies, whose jurisdiction in most legal systems is normally limited in substantive and geographical terms, should have the authority to bind all agencies entrusted with administrative enforcement throughout the territory of a WTO Member, such as the European Communities. ${ }^{636}$

${ }^{635}$ Panel Report, para. 7.537.

${ }^{636}$ Ibid., para. 7.538. We note that the European Communities and its member States are WTO Members in their own rights. 
WT/DS315/AB/R

Page 112

291. On appeal, the United States claims that the Panel failed to give meaning to the terms "the agencies entrusted with administrative enforcement" and "such agencies" in Article X:3(b). ${ }^{637}$ In the United States' view, the Panel effectively disregarded the ordinary meaning of these terms when it stated that "it is difficult to know what significance should be attached, if any, to the reference to agencies in the plural." ${ }^{638}$ The United States submits that the ordinary meaning of the plural form encompasses "the agencies"—without limitation—as opposed to only one such agency, or just "some of" or "a subset of" the agencies. The use of the plural form contemplates multiple agencies and, given the absence of any basis in the text for distinguishing among multiple agencies, it must contemplate all the agencies entrusted with administrative enforcement. ${ }^{639}$ Furthermore, the United States maintains that Article X:3(b) must be read in the light of the requirement of uniform administration in Article X:3(a) of the GATT 1994, and that it follows from this context that procedures leading to decisions that have effect only in particular regions of a Member's territory are inconsistent with Article X:3(b) of the GATT 1994.

292. In the European Communities' view, the Panel correctly explained that the use of the plural form when referring to "agencies" in Article X:3(b) could flow from the fact that the review "tribunals and procedures" required under the same provision are also referred to in the plural. ${ }^{640}$ The European Communities concurs with the Panel that it would not be reasonable to infer "that first instance independent review tribunals and bodies, whose jurisdiction in most legal systems is normally limited in substantive and geographical terms, should have the authority to bind all agencies entrusted with administrative enforcement throughout the territory of a [WTO] Member."641 Furthermore, the European Communities submits that the absence of an express reference to Article X:3(a) in Article X:3(b) of the GATT 1994 contrasts with the explicit reference in Article X:3(c) to Article X:3(b) of the GATT 1994, and argues that this absence precludes an inference that the obligation to ensure review of administrative action under Article $\mathrm{X}$ :3(b) could be read as simultaneously requiring uniform administration within the meaning of Article X:3(a) of the GATT 1994.

\footnotetext{
${ }^{637}$ United States' appellant's submission, paras. 164-172.

${ }^{638}$ Panel Report, para. 7.528.

${ }^{639}$ United States' appellant's submission, para. 166.

${ }^{640}$ European Communities' appellee's submission, para. 288 (referring to Panel Report, para. 7.527).

${ }^{641}$ Ibid., para. 325 (referring to United States' appellant's submission, para. 188).
} 
293. Our analysis begins with the text of Article X:3(b) of the GATT 1994, which stipulates:

Each Member shall maintain, or institute as soon as practicable, judicial, arbitral or administrative tribunals or procedures for the purpose, inter alia, of the prompt review and correction of administrative action relating to customs matters. Such tribunals or procedures shall be independent of the agencies entrusted with administrative enforcement and their decisions shall be implemented by, and shall govern the practice of, such agencies unless an appeal is lodged with a court or tribunal of superior jurisdiction within the time prescribed for appeals to be lodged by importers; Provided that the central administration of such agency may take steps to obtain a review of the matter in another proceeding if there is good cause to believe that the decision is inconsistent with established principles of law or the actual facts. (original emphasis)

294. At the outset, we note that both parties agree that Article X:3(b) relates to first instance review. The Panel agreed with this interpretation. It found support for this interpretation in the separate reference in Article X:3(b) to the possibility of filing an appeal with "a court or tribunal of superior jurisdiction within the time prescribed for appeals to be lodged by importers". We agree that the phrase "unless an appeal is lodged with a court or tribunal of superior jurisdiction" contemplates the possibility that there may be an appeal to bodies of "superior jurisdiction" and confirms the view that Article X:3(b) relates to first instance review. We note that the Panel also relied on the proviso of Article X:3(b), which provides that the "central administration of such agency may take steps to obtain a review of the matter in another proceeding if there is good cause to believe that the decision is inconsistent with established principles of law or the actual facts." ${ }^{1642}$

295. Article X:3(b) requires that first instance review decisions "shall be implemented by, and shall govern the practice of, such agencies" (that is, agencies entrusted with the administration of customs matters). The question before us is whether, as argued by the United States, Article X:3(b) requires that first instance review decisions must govern the practice of all the agencies entrusted with administrative enforcement throughout the territory of a WTO Member.

296. The United States emphasizes that Article X:3(b) contains two separate references to "agencies" in the plural: the first reference is to "the agencies entrusted with administrative enforcement"; and the second reference is to "such agencies". ${ }^{643}$ From that, the United States infers that review decisions should govern the practice of "all of the agencies entrusted with administrative enforcement". We address each of these references in turn.

\footnotetext{
${ }^{642}$ Panel Report, para. 7.521.

${ }^{643}$ United States' appellant's submission, para. 166.
} 
WT/DS315/AB/R

Page 114

297. The use in Article $\mathrm{X}: 3(\mathrm{~b})$ of the term "the agencies entrusted with administrative enforcement" in the plural form suggests that reference is made to more than a single agency. However, it does not follow from the use of the plural that first instance review decisions concerning administrative action taken by an agency must necessarily be binding on all other agencies throughout a WTO Member's territory. In our view, the interpretation proposed by the United States would mean reading words into the treaty text that are not there. We can conceive of several explanations for the use of the plural when referring to "agencies" in Article X:3(b) of the GATT 1994: there could be several agencies in a WTO Member having different areas of substantive competence; various agencies could also have competence for different geographical areas. The use of the plural for "agencies" might also be a consequence of the reference to "tribunals" and "procedures" in the plural. ${ }^{644}$ The reference to "tribunals" and "procedures" in the plural suggests to us that WTO Members are free to establish several first instance review tribunals and procedures that have different substantive or geographic areas of competence. Article X:3(b) does not, in our view, preclude a WTO Member from establishing first instance review tribunals and procedures governing the practice of all administrative agencies in their entire territory; however, it also does not require WTO Members to do so. Therefore, we are not convinced that the reference to "agencies" in the plural implies that first instance review decisions must govern the practice of "all agencies" of a WTO Member.

298. The United States also argues that the absence of criteria for distinguishing among multiple "agencies" implies that the reference to "such agencies" means all agencies. A plain reading of Article X:3(b) suggests that "such agencies" are not all agencies, but only those agencies whose action has been subject to review by a tribunal or procedure and that are bound by the decisions of that tribunal or procedure "with respect to identical factual situations that may arise in the future concerning identical legal issues". ${ }^{645}$ We agree with the Panel that what is required by Article X:3(b) is that "the decisions of judicial, arbitral or administrative tribunals and procedures for the prompt review and correction of administrative action must govern the practice of the agency whose action was the subject of review by a tribunal or procedure in a particular case." ${ }^{646}$ Article X:3(b) leaves the specific structure of the review mechanism to the discretion of the Member concerned. Therefore, "such agencies" may encompass more or fewer agencies depending on the structure of the review mechanism. However, we do not see why the jurisdiction of a review tribunal or procedure and the binding effect of a review decision of that tribunal would always or necessarily have to extend to all agencies of a Member.

\footnotetext{
${ }^{644}$ European Communities' appellee's submission, para. 288.

${ }^{645}$ Panel Report, para. 7.531.

${ }^{646}$ Ibid., para. 7.528.
} 
299. In addition, we recall that Article X:3(b) relates to first instance review and contemplates the possibility of appeals to bodies of "superior jurisdiction" as well as the seeking of "a review of the matter" by a centralized agency. This would also suggest that the first instance review required by that provision need not necessarily cover the entire territory of a WTO Member.

300. Accordingly, we are of the view that it does not follow from the ordinary meaning of Article X:3(b) that decisions of judicial, arbitral, or administrative tribunals or procedures for first instance review and correction of administrative action relating to customs matters must govern the practice of all the agencies entrusted with administrative enforcement throughout the territory of a WTO Member.

301. We address next the question whether context suggests otherwise. We consider that Article X:3(a) of the GATT 1994 is relevant as context. The Panel, however, noted that Article X:3(b) of the GATT 1994 does not contain an express textual link to the obligation of uniform administration of customs laws in Article X:3(a). The Panel contrasted this with Article X:3(c) of the GATT 1994, which explicitly cross-references Article X:3(b) ${ }^{647}$ Against this background, the Panel considered that it was not possible to infer that the drafters of the GATT 1994 intended the obligation of Article X:3(b) to be read as simultaneously requiring uniform administration in accordance with Article X:3(a). In the Panel's view, this would amount to "merging different requirements that are currently contained in separate sub-paragraphs of Article X". ${ }^{648}$ We see no reason to disagree with the Panel's interpretation. We are also of the view that the requirement of "uniformity" contained in Article X:3(a) does not imply that under Article X:3(b) decisions of review tribunals must govern the practice of all agencies entrusted with customs enforcement throughout the territory of a WTO Member. Article X:3(a) requires, inter alia, uniformity of administration. In contrast, Article X:3(b) relates to the review and correction of administrative action by independent mechanisms.

302. Finally, turning briefly to the treaty's object and purpose, we note the Panel's view that the due process objective underlying Article X:3(b) is that "a trader who has been adversely affected by a decision of an administrative agency has the ability to have that adverse decision reviewed." ${ }^{649}$ We believe this due process objective is not undermined even if first instance review decisions do not govern the practice of all the agencies entrusted with customs enforcement throughout the territory of a WTO Member, so long as there is a possibility of an independent review and correction of the administrative action of every agency.

\footnotetext{
${ }^{647}$ Likewise, this is in contrast with Article X:3(a), which contains a cross-reference to Article X:1.

${ }^{648}$ Panel Report, paras. 7.534.

${ }^{649}$ Ibid., para. 7.538 .
} 
WT/DS315/AB/R

Page 116

303. For these reasons, we are of the view that Article X:3(b) of the GATT 1994 requires a WTO Member to establish and maintain independent mechanisms for prompt review and correction of administrative action in the area of customs administration. However, neither text nor context nor the object and purpose of this Article require that the decisions emanating from such first instance review must govern the practice of all agencies entrusted with administrative enforcement throughout the territory of a particular WTO Member.

304. We therefore uphold the conclusion of the Panel, in paragraphs 7.539, 7.556, and 8.1(e) of the Panel Report, that "Article X:3(b) of the GATT 1994 does not necessarily mean that the decisions of the judicial, arbitral or administrative tribunals or procedures for the review and correction of administrative action relating to customs matters must govern the practice of all agencies entrusted with administrative enforcement throughout the territory of a particular [WTO] Member." ${ }^{\text {650 }}$ We conclude that the Panel did not err in finding the tribunals and procedures for review of customs administrative action provided by the European Communities to be consistent with Article X:3(b) of the GATT 1994.

\section{Conditional Appeal of the European Communities}

305. The Panel found that Article XXIV:12 of the GATT 1994 cannot be relied upon to attenuate or to derogate from the provisions of the GATT 1994 (including Article X:3(a)), to which Article XXIV:12 refers. ${ }^{651}$ In the light of this reasoning, the Panel concluded:

Article XXIV:12 of the GATT does not constitute an exception nor a derogation from the obligation of uniform administration in Article X:3(a) of the GATT 1994. Therefore, Article XXIV:12 of the GATT 1994 has no impact upon our examination of the United States' claims under Article X:3(a) of the GATT $1994{ }^{652}$ (footnote omitted)

306. The European Communities conditionally appeals this finding in the event that the Appellate Body's conclusions on the United States' appeal imply that the European Communities should "create a centralised customs agency replacing its [m]ember States in the implementation of [European Communities] customs law"1653, or that the European Communities should "create an [European Communities]-level tribunal for the first-instance review of customs decisions". 654

\footnotetext{
${ }^{650}$ (original emphasis)

${ }^{651}$ Panel Report, para. 7.144. (footnote omitted)

${ }^{652}$ Ibid., para. 7.145 .

${ }^{653}$ European Communities' other appellant's submission, para. 235.

${ }^{654}$ Ibid.
} 
307. The United States requests the Appellate Body to reject the European Communities' conditional appeal because the question of the possible relevance of Article XXIV:12 of the GATT 1994 is outside the scope of these appellate proceedings and because this provision applies to the observance of GATT 1994 laws by regional and local governments and authorities, which is not at issue in this appeal.

308. We already found that we were unable to complete the analysis with respect to whether the measures at issue, taken as a whole, have been administered in a manner inconsistent with the requirements in Article X:3(a) of the GATT 1994. In addition, we upheld the Panel's conclusion that the European Communities did not breach Article X:3(b) of the GATT 1994. It thus follows that the conditions on which this aspect of the European Communities' appeal is predicated are not satisfied. Therefore we do not consider it further.

\section{Findings and Conclusions}

309. For the reasons set out in this Report, the Appellate Body:

(a) with respect to the Panel's terms of reference:

(i) reverses the Panel's finding, in paragraph 7.20 of the Panel Report, that the "measure at issue" for purposes of a claim under Article X:3(a) of the GATT 1994 must necessarily be "the manner of administration that is allegedly non-uniform, partial and/or unreasonable";

(ii) $\quad$ reverses the Panel's finding, in paragraphs 7.33 and 8.1(a)(i) of the Panel Report, that the specific measure at issue in this dispute is "the manner of administration $\ldots$ of the Community Customs Code, the Implementing Regulation, the Common Customs Tariff, the TARIC and related measures in the areas of customs administration specifically identified in the United States' request for establishment of a panel"655; and finds, instead, that the specific measures at issue identified in the panel request are the Community Customs Code, the Implementing Regulation, the Common Customs Tariff, and the TARIC, as administered collectively;

\footnotetext{
${ }^{655}$ Panel Report, para. 8.1(a)(i).
} 
(iii) reverses the Panel's finding, in paragraphs 7.50, 7.64, and 8.1(a)(iii) of the Panel Report, that, due to the wording and content of the panel request, the United States was precluded from challenging the European Communities' system of customs administration as a whole or overall; and reverses also the Panel's finding, in paragraphs 7.63, 7.64, and 8.1(a)(iii) of the Panel Report, that the Panel was precluded from considering the United States' argument that the "design and structure" of the European Communities' system of customs administration necessarily result in a violation of Article X:3(a) of the GATT 1994; and

(iv) upholds, albeit for different reasons, the Panel's interpretation, in paragraph 7.37 of the Panel Report, that "the steps and acts of administration that pre-date or post-date the establishment of a panel may be relevant to determining whether or not a violation of Article X:3(a) of the GATT 1994 exists at the time of [panel] establishment";

(b) with respect to claims under Article X:3(a) of the GATT 1994:

(i) reverses the Panel's finding, in paragraph 7.119 of the Panel Report, that, without exception, Article X:3(a) of the GATT 1994 always relates to the application of laws and regulations, but not to laws and regulations as such; but upholds the Panel's conclusions, in paragraphs 7.434, 7.444, 8.1(d)(i), and 8.1(d)(ii) of the Panel Report, that substantive differences in penalty laws and audit procedures among the member States of the European Communities alone do not constitute a violation of Article X:3(a) of the GATT 1994;

(ii) concludes that the Panel did not find that Article X:3(a) of the GATT 1994 requires uniformity of "administrative processes"; upholds the Panel's finding, in paragraph 7.119 of the Panel Report, that the term "administer" in Article X:3(a) of the GATT 1994 may include administrative processes that put into effect the legal instruments of the kind described in Article X:1 of the GATT 1994; but reverses the Panel's finding, in paragraphs 7.276 and 8.1(b)(iv) of the Panel Report, that the administrative process leading to the tariff classification of blackout drapery lining amounts to non-uniform administration within the meaning of Article X:3(a) of the GATT 1994, and that the European Communities has violated Article X:3(a) of the GATT 1994 with respect to the tariff classification of blackout drapery lining; 
(iii) upholds the Panel's finding, in paragraphs 7.305 and 8.1(b)(v) of the Panel Report, that "[t]he tariff classification of liquid crystal display monitors with digital video interface amounts to non-uniform administration within the meaning of Article X:3(a) of the GATT 1994";

(iv) reverses the Panel's finding, in paragraphs 7.385 and 8.1(c)(ii) of the Panel Report, that "the European Communities does not administer its customs law concerning successive sales-in particular, Article 147(1) of the Implementing Regulation-in a uniform manner, in violation of Article X:3(a) of the GATT 1994"; and

(v) is unable to complete the analysis with respect to the United States' claim that the European Communities' system of customs administration as a whole or overall is not administered in a uniform manner, as required by Article X:3(a) of the GATT 1994;

(c) with respect to Article X:3(b) of the GATT 1994:

upholds the conclusion of the Panel, in paragraphs 7.539, 7.556, and 8.1(e) of the Panel Report, that "Article X:3(b) of the GATT 1994 does not necessarily mean that the decisions of the judicial, arbitral or administrative tribunals or procedures for the review and correction of administrative action relating to customs matters must govern the practice of all the agencies entrusted with administrative enforcement throughout the territory of a particular [WTO] Member"656; and

(d) with respect to Article XXIV:12 of the GATT 1994:

finds that the conditions on which the European Communities' appeal is predicated are not satisfied, and therefore does not consider it.

310. The Appellate Body recommends that the DSB request the European Communities to bring its measures, which have been found in this Report, and in the Panel Report as modified by this Report, to be inconsistent with the GATT 1994, into conformity with its obligations under that Agreement.

${ }^{656}$ (original emphasis) 
WT/DS315/AB/R

Page 120

Signed in the original in Geneva this 27th day of October 2006 by:

A.V. Ganesan

Presiding Member

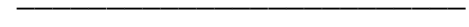

Merit E. Janow

Member
Yasuhei Taniguchi

Member 


\title{
$\underline{\text { ANNEX I }}$
}

\section{WORLD TRADE}

\section{ORGANIZATION}

WT/DS315/11

17 August 2006

$(06-3905)$

Original: English

\section{EUROPEAN COMMUNITIES - SELECTED CUSTOMS MATTERS}

\author{
Notification of an Appeal by the United States \\ under Article 16.4 and Article 17 of the Understanding on Rules \\ and Procedures Governing the Settlement of Disputes (DSU), \\ and under Rule 20(1) of the Working Procedures for Appellate Review
}

The following notification, dated 14 August 2006, from the Delegation of the United States, is being circulated to Members.

Pursuant to Article 16 of the Understanding on Rules and Procedures Governing the Settlement of Disputes ("DSU") and Rule 20 of the Working Procedures for Appellate Review, the United States hereby notifies its decision to appeal to the Appellate Body certain issues of law covered in the Report of the Panel on European Communities - Selected Customs Matters (WT/DS315/R) and certain legal interpretations developed by the Panel. of the Panel.

The United States seeks review by the Appellate Body of the following aspects of the Report

\section{I. $\quad$ Terms of Reference}

The United States seeks review of three sets of errors committed by the Panel with respect to its analysis of its terms of reference.

(A) As the first step in its analysis the Panel found, in paragraph 7.20 of the Report, that "when a violation of Article X:3(a) of the [General Agreement on Tariffs and Trade 1994] is being claimed," the "measure at issue" that Article 6.2 requires to be identified in the request for establishment of a panel is "the manner of administration that is allegedly non-uniform, partial and/or unreasonable." This finding is in error and is based on erroneous findings on issues of law and related legal interpretations contained in paragraphs 7.8 through 7.22 of the Panel Report. In making this finding, the Panel misinterpreted or misapplied Article 6.2 of the DSU.

While the Panel's finding that "manner of administration" is the measure at issue in a dispute involving Article X:3(a) of the General Agreement on Tariffs and Trade 1994 ("GATT 1994") was in error and should not be allowed to stand, the U.S. panel request did in fact identify the manner of administration of European Communities ("EC") laws, regulations, decisions, and rulings of the kind described in Article X:1 of the GATT 1994 at issue (referred to hereafter collectively as "EC customs law"), and the Panel did not find against the United States on this ground. 
(B) Having incorrectly found "manner of administration" to be the measure at issue in a dispute involving Article X:3(a) of the GATT 1994, the Panel also misconstrued the specific measures at issue identified in the U.S. panel request as confined to the manner of administration of EC customs law in certain specific areas, as opposed to the manner of administration of such measures irrespective of area. Thus, the Panel found in paragraph 7.33 of the Report that the "specific measure at issue" in this dispute, within the meaning of Article 6.2 of the DSU, was:

[T] he manner of administration by the national customs authorities of the member States of the Community Customs Code, the Implementing Regulation, the Common Customs Tariff, the TARIC and related measures in the areas of customs administration specifically identified in the United States' request for establishment of a panel - namely, the classification and valuation of goods, procedures for the classification and valuation of goods, procedures for the entry and release of goods, procedures for auditing entry statements after goods are released into free circulation, penalties and procedures regarding the imposition of penalties for violation of customs rules and record-keeping requirements.

This finding is in error and is based on erroneous findings on issues of law and related legal interpretations contained in paragraphs 7.23 through 7.32 and 8.1(a)(i) of the Panel Report. In making this finding, the Panel misinterpreted or misapplied Articles 6.2 and 7.1 of the DSU.

(C) The Panel then made the erroneous legal conclusion that its terms of reference excluded the U.S. claim that the design and structure of the EC system of customs administration as a whole results in the administration of EC customs law in a non-uniform manner, contrary to Article X:3(a) of the GATT 1994. For example, paragraph 7.50 of its Report, the Panel made the erroneous finding that "its terms of reference regarding the U.S. claim under Article X:3(a) of the GATT 1994 do not include a challenge to the EC system of customs administration overall or as a whole under Article X:3(a) of the GATT 1994." The Panel made a similarly erroneous finding in paragraph 7.63, stating that "the United States is precluded from making an 'as such' challenge with respect to the design and structure of the EC system of customs administration as a whole and also with respect to the design and structure of the EC system in the areas of customs administration that have been specifically identified in the United States' request." This finding is repeated at paragraph 8.1(a)(iii) of the Panel's Report.

These findings are in error and are based on erroneous findings on issues of law and related legal interpretations contained in paragraphs 7.11 through 7.20, 7.23 through 7.32, 7.40 through 7.50, 7.53 through 7.63, and 8.1(a)(iii) of the Panel Report. In making these findings, the Panel misinterpreted or misapplied Articles 6.2 and 7.1 of the DSU.

The Panel's error in excluding from its terms of reference the U.S. challenge with respect to the EC system of customs administration as a whole did not depend on its first two errors with respect to its terms of reference. Even if the first two findings in the Panel's analysis of its terms of reference were correct (which we contend they were not), the Panel still should not have excluded the U.S. challenge with respect to the EC's system of customs administration as a whole. The U.S. claim was about features that are absent from the EC system of customs administration, which result in the EC administering its customs laws in a non-uniform manner, contrary to Article X:3(a) of the GATT 1994. That central aspect of the U.S. complaint - which was evident from the panel request, elaborated in U.S. submissions and statements, and well understood by the EC as evidenced by its submissions and statements - was part of the U.S. panel request whether that request is understood as encompassing the administration of EC customs law in all areas or only in certain areas (as the Panel found). 
Accordingly, the United States asks the Appellate Body to reverse the Panel's finding that this claim was outside the Panel's terms of reference. Additionally, the United States asks the Appellate Body to complete the Panel's analysis based on the undisputed facts and the Panel's factual findings regarding the EC system of customs administration. In light of the Panel's factual findings that the various institutions and mechanisms that the EC held out as securing the uniform administration of its customs laws - in an environment where administration is the responsibility of 25 separate, independent customs authorities - do not actually do so, the Appellate Body should find that the EC system of customs administration as a whole results in the non-uniform administration of EC customs law, in breach of Article X:3(a) of the GATT 1994.

II. Interpretation of the term "administer" in Article X:3(a) of the GATT 1994 as it relates to the existence of divergent penalty laws and audit procedures

The United States seeks review of the Panel's legal conclusions that the existence of divergent penalty laws and audit procedures are not inconsistent with Article X:3(a) of the GATT 1994, and the related issues of law and legal interpretation. At paragraph 7.444, for example, the Panel found "no violation of Article X:3(a) of the GATT 1994 with respect to the substantive differences in penalty laws between member States." At paragraph 7.434, for example, the Panel found "no violation of Article X:3(a) of the GATT 1994 with respect to the manner of administration of the audit procedure requirements in the European Communities by the member States applicable to goods following their release for free circulation."

In finding that the EC does not breach its Article X:3(a) obligation of uniform administration to the extent that it puts EC customs law into practical effect through divergent penalty laws and audit procedures, the Panel erred in its interpretation of the term "administer" as used in that provision. The Panel's error regarding its approach to differences in customs penalty laws is based on erroneous findings on issues of law and related legal interpretations contained in paragraphs 7.113 through 7.119, 7.442 through 7.444, and 8.1(d)(ii) of the Panel Report. Its error regarding its approach to differences in audit procedures is based on erroneous findings on issues of law and related legal interpretations contained in paragraphs 7.113 through 7.119, 7.425 through 7.434, and 8.1(d)(i) of the Panel Report.

The United States asks the Appellate Body to reverse the Panel's legal conclusions that the existence of divergent penalty laws and audit procedures are not inconsistent with Article X:3(a) of the GATT 1994. The United States further asks the Appellate Body to complete the Panel's analysis. In light of the Panel's findings and undisputed facts regarding the existence of divergent penalty laws and audit procedures, the Appellate Body should find that the EC fails to administer EC customs law in a uniform manner, in breach of Article X:3(a) of the GATT 1994, to the extent it gives effect to EC customs law through the maintenance of divergent penalty laws and audit procedures.

III. Interpretation of Article X:3(b) of the GATT 1994

The United States seeks review of the Panel's legal conclusion that "the European Communities does not violate Article X:3(b) of the GATT 1994 merely because the decisions regarding review of administration action relating to customs matters, which are taken by authorities in the member States acting as organs of the European Communities, do not apply and have effect throughout the territory of the European Communities." Panel Report, para. 7.554; id., paras. 7.539, 7.556, and 8.1(e). That conclusion represents an erroneous interpretation of Article X:3(b) of the GATT 1994, which was based on erroneous findings on issues of law and related legal interpretations contained in paragraphs 7.526 through 7.538 . 
WT/DS315/AB/R

Page 124

The United States asks the Appellate Body to reverse the Panel's erroneous interpretation of and conclusion under Article X:3(b). Further, the United States asks the Appellate Body to complete the Panel's analysis. It is undisputed that each of the tribunals and procedures the EC provides is limited to reviewing the administrative actions of the customs authority within a particular EC member State. It also is undisputed that none of these tribunals or procedures issues decisions that govern the practice of all of the agencies entrusted with administrative enforcement of the EC's customs law (that is, the customs authorities of the 25 EC member States). In light of these undisputed facts, the Appellate Body should find that the EC is in breach of its obligation under Article X:3(b) of the GATT 1994. 


\section{WORLD TRADE}

\section{ORGANIZATION}

WT/DS315/12

28 August 2006

$(06-4123)$

Original: English

\section{EUROPEAN COMMUNITIES - SELECTED CUSTOMS MATTERS}

Notification of an Other Appeal by the European Communities under Article 16.4 and Article 17 of the Understanding on Rules and Procedures Governing the Settlement of Disputes (DSU), and under Rule 23(1) of the Working Procedures for Appellate Review

The following notification, dated 28 August 2006, from the Delegation of the European Commission, is being circulated to Members.

1. Pursuant to Article 16.4 and Article 17 of the DSU and to Rule 23.1 of the Working Procedures for Appellate Review, the European Communities submits its Notice of Other Appeal on certain issues of law in the Report of the Panel on European Communities - Selected Customs Matters $^{1}$ and certain legal interpretations developed by the Panel.

2. The European Communities seeks review by the Appellate Body of the following:

(a) the Panel's decision not to admit certain evidence submitted by the European Communities during the interim review stage, and in particular Exhibits EC-167 to EC-170 (paragraphs 6.5 and 6.6 of the Panel report). This decision is incompatible with Article 15.2 of the DSU and with the Panel's duty to make an objective assessment of the facts as required by Article 11 of the DSU;

(b) the Panel's finding regarding the temporal limitations of its terms of reference, according to which it may consider measures, including acts of administration, which were no longer in existence, or not yet in existence, at the time of its establishment (paragraph 7.36 to 7.37 of the Panel Report). These findings are inconsistent with Articles 6.2 and 7.1 of the DSU;

(c) the Panel's finding that Article X:3(a) GATT requires uniformity of administrative processes irrespective of their impact on the uniform administration of the laws (paragraphs 7.102 to 7.113 and 7.119 of the Report). This finding is based on an incorrect interpretation of Article X:3(a) GATT;

\footnotetext{
${ }^{1}$ WT/DS315/R, circulated on 16 June 2005.
} 
(d) the Panel's finding that Article XXIV:12 GATT cannot be relied upon to attenuate or to derogate from the provisions of the GATT 1994, including Article X:3 GATT, and does not constitute an exception from such provisions (paragraphs 7.140 to 7.145 of the Panel Report). This finding is based on an incorrect interpretation Article XXIV:12 GATT;

(e) the Panel's finding that the EC has violated Article X:3(a) GATT with respect to the process leading to the tariff classification of blackout drapery lining (paragraphs 7.266 to 7.276, 8.1(b)(iv) and 8.2(a) of the Panel Report). In reaching this finding, the Panel has erred in its interpretation of Article X:3(a) GATT, and failed to make an objective assessment of the facts as required by Article 11 of the DSU;

(f) the Panel's finding that the EC has violated Article X:3(a) GATT with respect to the tariff classification of LCD Monitors with DVI (paragraphs 7.291 to 7.305, 8.1(b)(v) and 8.2(b) of the Panel Report). In reaching this finding, the Panel has erred in its interpretation of Article X:3(a) GATT, and failed to make an objective assessment of the facts as required by Article 11 of the DSU;

(g) the Panel's finding that the EC has violated Article X:3(a) GATT with respect to the imposition by the customs authorities of certain Member States of a form of prior approval with respect to the successive sales provision (paragraphs 7.376 to 7.385 , 8.1(c)(ii) and 8.2(c) of the Panel Report). In reaching this finding, the Panel has erred in its interpretation of Article X:3(a) GATT, and failed to make an objective assessment of the facts as required by Article 11 of the DSU. 


\title{
WORLD TRADE
}

\section{ORGANIZATION}

WT/DS315/8

14 January 2005

$(05-0192)$

Original: English

\section{EUROPEAN COMMUNITIES - SELECTED CUSTOMS MATTERS}

\author{
Request for the Establishment of a Panel by the United States
}

The following communication, dated 13 January 2005, from the delegation of the United States to the Chairperson of the Dispute Settlement Body, is circulated pursuant to Article 6.2 of the DSU.

The United States considers that the manner in which the European Communities ("EC") administers its laws, regulations, decisions and rulings of the kind described in Article X:1 of the General Agreement on Tariffs and Trade 1994 ("GATT 1994") is not uniform, impartial and reasonable, and therefore is inconsistent with Article X:3(a) of the GATT 1994. For purposes of this request, the laws, regulations, decisions and rulings (collectively, "measures") that the European Communities fails to administer in such a manner pertain to the classification and valuation of products for customs purposes and to requirements, restrictions or prohibitions on imports. The measures consist of:

- $\quad$ Council Regulation (EEC) No 2913/92 of 12 October 1992 establishing the Community Customs Code, including all annexes thereto, as amended (the "Code");

- $\quad$ Commission Regulation (EEC) No 2454/93 of 2 July 1993 laying down provisions for the implementation of Council Regulation (EEC) No 2913/92 of 12 October 1992 establishing the Community Customs Code, including all annexes thereto, as amended (the "Commission Regulation");

- $\quad$ Council Regulation (EEC) No 2658/87 of 23 July 1987 on the tariff and statistical nomenclature and on the Common Customs Tariff, including all annexes thereto, as amended (the "Tariff Regulation");

- $\quad$ the Integrated Tariff of the European Communities established by virtue of Article 2 of Council Regulation (EEC) No 2658/87 of 23 July 1987 on the tariff and statistical nomenclature and on the Common Customs Tariff, including all annexes thereto, as amended (the "TARIC"); and

- $\quad$ for each of the above laws and regulations, all amendments, implementing measures and other related measures. 
Administration of these measures in the European Communities is carried out by the national customs authorities of EC member States. Such administration takes numerous different forms. The United States understands that the myriad forms of administration of these measures include, but are not limited to, laws, regulations, handbooks, manuals, and administrative practices of customs authorities of member States of the European Communities.

Lack of uniform, impartial and reasonable administration of the above-identified measures is manifest in differences among member States in a number of areas, including, but not limited to, the following:

- $\quad$ classification and valuation of goods;

- $\quad$ procedures for the classification and valuation of goods, including the provision of binding classification and valuation information to importers;

- $\quad$ procedures for the entry and release of goods, including different certificate of origin requirements, different criteria among member States for the physical inspection of goods, different licensing requirements for importation of food products, and different procedures for processing express delivery shipments;

- $\quad$ procedures for auditing entry statements after goods are released into the stream of commerce in the European Communities;

- $\quad$ penalties and procedures regarding the imposition of penalties for violation of customs rules; and

- $\quad$ record-keeping requirements.

In addition, the European Communities has failed to maintain, or institute as soon as practicable, judicial, arbitral or administrative tribunals or procedures for the purpose, inter alia, of the prompt review and correction of administrative action relating to customs matters. The above-identified measures, including in particular Articles 243 through 246 of the Code, expressly provide that EC member States are responsible for the implementation of procedures for appeals from decisions by member State customs authorities. Accordingly, the ability to obtain review of a customs decision by a tribunal of the European Communities does not arise until after an importer or other interested party has pursued review through national administrative and/or judicial tribunals. For this reason, the European Communities is in breach of Article X:3(b) of the GATT 1994.

The EC measures are also inconsistent with Article X:1 of the GATT 1994.

On 21 September 2004, the United States requested consultations with the European Communities pursuant to Articles 1 and 4 of the Understanding on Rules and Procedures Governing the Settlement of Disputes ("DSU") and Article XXII:1 of the GATT 1994 (WT/DS315/1). The United States held consultations with the European Communities in Geneva on 16 November 2004. Unfortunately, these consultations did not resolve the dispute.

Accordingly, the United States respectfully requests the Dispute Settlement Body to establish a panel pursuant to Article 6 of the DSU to examine this matter with standard terms of reference as set out in Article 7.1 of the DSU. 